Carleton University

\title{
Edgard Leuenroth - The Formative Years, 1881-1917: Exploring Anarchist Ideology in São Paulo through Critical Biography
}

\begin{abstract}
A thesis submitted to the Faculty of Graduate Studies and Research in partial fulfillment of the requirements for the degree of Master of Arts
\end{abstract}

Institute of Political Economy

by

Matthew Lymburner

Ottawa, Ontario

July 2008

(C) 2008, Matthew Lymburner 


$\begin{array}{ll}\begin{array}{l}\text { Library and } \\ \text { Archives Canada }\end{array} & \begin{array}{l}\text { Bibliothèque et } \\ \text { Archives Canada }\end{array} \\ \begin{array}{l}\text { Published Heritage } \\ \text { Branch }\end{array} & \begin{array}{l}\text { Direction du } \\ \text { Patrimoine de l'édition }\end{array} \\ \begin{array}{l}\text { 395 Wellington Street } \\ \text { Ottawa ON K1A 0N4 } \\ \text { Canada }\end{array} & \begin{array}{l}\text { 395, rue Wellington } \\ \text { Ottawa ON K1A 0N4 } \\ \text { Canada }\end{array}\end{array}$

Your file Votre référence ISBN: 978-0-494-43476-5 Our file Notre référence ISBN: 978-0-494-43476-5

NOTICE:

The author has granted a nonexclusive license allowing Library and Archives Canada to reproduce, publish, archive, preserve, conserve, communicate to the public by telecommunication or on the Internet, loan, distribute and sell theses worldwide, for commercial or noncommercial purposes, in microform, paper, electronic and/or any other formats.

The author retains copyright ownership and moral rights in this thesis. Neither the thesis nor substantial extracts from it may be printed or otherwise reproduced without the author's permission.
AVIS:

L'auteur a accordé une licence non exclusive permettant à la Bibliothèque et Archives Canada de reproduire, publier, archiver, sauvegarder, conserver, transmettre au public par télécommunication ou par l'Internet, prêter, distribuer et vendre des thèses partout dans le monde, à des fins commerciales ou autres, sur support microforme, papier, électronique et/ou autres formats.

L'auteur conserve la propriété du droit d'auteur et des droits moraux qui protège cette thèse. $\mathrm{Ni}$ la thèse ni des extraits substantiels de celle-ci ne doivent être imprimés ou autrement reproduits sans son autorisation.
In compliance with the Canadian Privacy Act some supporting forms may have been removed from this thesis.

While these forms may be included in the document page count, their removal does not represent any loss of content from the thesis.
Conformément à la loi canadienne sur la protection de la vie privée, quelques formulaires secondaires ont été enlevés de cette thèse.

Bien que ces formulaires aient inclus dans la pagination, il n'y aura aucun contenu manquant.

\section{Canada}




\begin{abstract}
This thesis studies the growth of anarchist ideology in São Paulo, Brazil between 1881 and 1917 through the partial biography of one of its main adherents, Edgard Leuenroth. It advances a specific methodological form of biography, dubbed 'critical biography' that aims to explore the 'negative space' of Leuenroth's life, alongside the 'positive space' that biographies have traditionally focused on. Chapter 1 sets up the ideological landscape by examining the specific beliefs of Edgard Leuenroth and provides a schematic for thinking about how ideological identity is produced. Chapter 2 charts Leuenroth's life from birth to age 36, providing arguments that explain the origins of Leuenroth's anarchist beliefs along the way. The final chapter moves to a higher level of abstraction, exploring some of the structural factors contributing to the growth of anarchism in the state, as well as the country more generally.
\end{abstract}




\section{Acknowledgements}

Needless to say, this thesis would certainly not exist right now if it were not for the direct and indirect help of countless people. First, I would like to thank the Arquivo Edgard Leuenroth, specifically Maria Cimelia Garcia and Sílvia Rosana Modena Martini for their diligent efforts in creating the "E-Album", an online biographical compilation and search instrument for Edgard Leuenroth and his archive. Their work served as both a starting point and a guide that I followed throughout my thesis project, without which I would certainly have gotten lost in the sheer size of the project.

I must also thank the people at Carleton University's Interlibrary Loans, in particular Christine Taylor, Callista Kelly, and Margaret McLeod for research assistance, and helping me obtain so many key texts that made this project possible. Alongside the Carleton library staff, my thanks go out to the employees at the Centre for Research Libraries who procured a selection of the very costly Latin American Anarchist and Labor Periodicals microfilm collection for my specific use. I would also like to acknowledge Maria Gonçalves for her help in proofreading some of the earliest translations I made. Her assistance gave me the confidence that I was capturing the importance of the message contained in each translation. Of course, any subsequent errors are my own.

This thesis would have not been possible without the immense moral, financial and institutional support of the Institute of Political Economy, specifically Donna Coghill \& Rianne Mahon. The work they do in shaping and honing the minds of the students who become a part of the Institute is inspirational. I would also like to thank all of the students in my cohort, especially Eliot Che, Emma Lui, Jim Dooley, Jason Wenczler, David Cavett-Goodwin, Allan Bevan, as well as Robyn Green, Benjamin Christensen, and those in the cohort after me. Whether the discussions were on the topic of my thesis or on something wholly different, the fruits of them will stay with me forever. Cristina Rojas, my supervisor, deserves great thanks for her patience and careful prodding to get me on a more focused track. Her assistance in helping me meet my personal deadlines took a big load off me when I was burdened the most. Blair Rutherford and Rianne Mahon also deserve extra thanks for their insightful comments, tough questions, and careful attention to detail as members of my committee.

Special thanks go to both my parents for their assistance along the way, financially, morally and editorially. Together they can claim credit for the best of this thesis (I reserve the worst for my own shortcomings).

Finally, the greatest thanks must go to Yumi, whose dedication as my proofreader, confidante, motivator - and biggest critic - ensured that the final product was completed in a timely fashion, and whose love and emotional support ensured that my stress level remained as low as it could during this whole process.

To everyone, and to all that I missed here: thank you. 


\section{Table of Contents}

Introduction: Why Biography? 1

Dilemmas of Biography: Lies, Silences, Sources and Scope 4

$\begin{array}{ll}\text { Critical Biography as Concept and Method } & 10\end{array}$

Looking to the Future: Variations of Critical Biography 13

$\begin{array}{ll}\text { Thesis Outline } & 14\end{array}$

Chapter 1: The Production of Ideological Identity: Conceptualizing the Anarchism of Edgard Leuenroth 17

Anarchism: A Philosophy and Praxis against Arbitrary Power 18

Principle and Praxis: The Anarchism of Edgard Leuenroth 21

Intersections: Biography, Identity, Ideology 27

The Production of Ideological Identity: Edgard Leuenroth 32

Chapter 2: Edgard Leuenroth: Formation and Growth, 1881-1917 39

I 40

II $\quad 50$

IIII 62

Chapter 3: The Structural Origins of Anarchism in Brazil 83

Mass Immigration, Anarchist Texts, and Homegrown Ideology 85

Transitional Industrialization, Class Relations, and Urban Dislocation $\quad 90$

The Old Republican State: Repression, Representation, and the

Diffusion of Authority 95

Brazilian National Identity(ies): Contesting Cultural Space 100

Conclusion: Connecting Structure to Agents 105

Conclusion: Between New and Old: Arguments and Scholarship 108

Anarchism and 'Race': New Avenues for Scholarship 108

Three Arguments on Three Levels 111

$\begin{array}{ll}\text { List of Works Cited } & 114\end{array}$ 


\section{List of Figures}

1.1 Fundamental Synthesis of the Bases of Anarchism 26

1.2 Factors Influencing Ideological Identity Formation 33

\section{List of Illustrations}

2.1 The house where Edgard Leuenroth was born and spent his earliest years

2.2 Edgard's father's pharmaceutical prescription pad 


\section{Introduction: Why Biography?}

When I first decided to write this biography of Edgard Leuenroth, I expected to undertake a challenging and fulfilling task that would culminate in a new sheaf of knowledge for English-speaking readers about a historically important, yet understudied Brazilian personality. The journey has far exceeded my expectations, both in the immense difficulties it has thrust in front of me, as well as in the satisfaction, and relief, of tentative completion - I leave it for the reader to decide whether I have succeeded in shoring up new knowledge or not. However, along the way, evidenced in both the significant alterations to my original proposal, and in a slow subjective and reflexive engagement with my method, my theoretical lens, and even the utility of my endeavor, I have had the opportunity to contemplate questions much larger than those contained within the scope of my thesis. These larger questions, I think, form a suitable backdrop for what is to come, and I would like to explore them briefly here. In the process, I seek to explain the merits and shortcomings of what I dub 'critical biography', and ultimately, just what it is I have tried to do in these pages.

The inspiration for this project came out of three personal passions: Brazilian history, political economy, and anarchism. While the recent growth in Republican-era Brazilian social historiography has been impossible to miss for historians of the region, there has also been a smaller "boom" in labor studies, pointed out by John D. French $^{1}$. Yet few in this period of renewed interest in the Brazilian labor movement have

\footnotetext{
${ }^{1}$ John D. French. "The Latin American Labor Studies Boom". International Review of Social History 45.
} 2000. pp. 279-308 
made anarchists their focal point ${ }^{2}$. John W.F. Dulles' Anarchists and Communists in Brazil, 1900-1935, published in 1973, largely remains the core English-language text documenting anarchist contributions to the labor movement. As comprehensive as this work is, its shortcomings were well noted soon after its publication. In a 1977 review, Ronald Chilcote pointed out that the book made "little effort...to draw conclusions and findings",

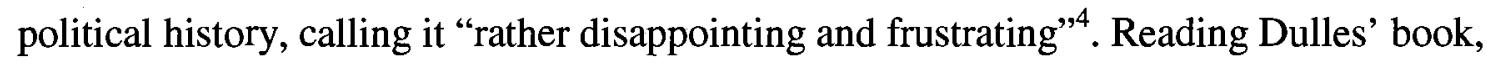
one is left without a satisfactory account of the relationships between anarchists, anarchosyndicalists, and the Brazilian labor movement, especially in the pre-1917 period, not just from a conceptual and analytic standpoint, but also concerning the reliability of some of his claims. Despite its lack of perfection, Dulles' sweeping book did highlight the efforts of many anarchists that had not previously received significant attention in the academic literature. One such anarchist was Edgard Leuenroth, whose partial biography forms the second chapter of this text.

Leuenroth represents an understudied figure in both the Brazilian labor movement, and in studies of Brazilian anarchism. I found this very peculiar - he is officially credited as being the mastermind of the 1917 São Paulo city general strike, and his personal repositories of data on Brazilian social movements (now part of the Arquivo Edgard Leuenroth) have been a boon for social historians and political economists working on Brazil. Indeed, it is largely in reference to this archive that Leuenroth's name is

\footnotetext{
${ }^{2}$ Indeed, anarchism in general is grossly understudied as an ideological phenomenon and as a cultural movement in academia, though since many principles of anarchism dovetail with those in postmodern thought, this has slowly begun to change.

${ }^{3}$ Ronald Chilcote "Book Review of Anarchists and Communists in Brazil, 1900-1935". American Political Science Review. Vol. 71, No. 1. 1977. pp. 376-7.

${ }^{4}$ Michael M. Hall. "Review: Anarchists and Communists in Brazil, 1900-1935". The Americas. Vol. 31, No. 2. 1974. p. 219.
} 
mentioned in the literature. Herein lies the central problem around which I constructed this thesis - there is still no systematic English-language text that critically appraises Leuenroth's contribution to either Brazilian anarchism or the labor movement.

I had initially fretted over the possibility of trying to do this in a simple Master's thesis, with the structural constraints of time and length, as well as limited funding to travel for research purposes. However, during the research and writing process I have realized that though Brazilian historiography still requires a full biography of this important figure, it would not be my role to provide it at this juncture, if that was my initial intention. Instead, I became interested in the historical project of deciphering Edgard Leuenroth's individual ideological identity formation through his biography. That is, I sought to understand why and how he would arrive at anarchism, and just what he meant by the term.

However, this is an academic endeavor fraught with tensions that social scientists are still in the process of resolving, as evidenced in continuing debates on historical method, and debates regarding the limits of appropriate social scientific scholarship. Even with the entrenchment of social history and the primacy given to the agent in accordance with the 'postmodern' developments of the last forty years, biographies remain somewhat taboo. Stanley Fish has recently attacked modern biography as "Minutiae without Meaning" denouncing its methodological value by claiming that biographers "can only get it wrong, can only lie, can only substitute their own story for the story of their announced subject" ${ }^{\text {, }}$ a sign that the acceptability of biography, regardless of its form, is still far from certain.

\footnotetext{
${ }^{5}$ Qtd. in Shirley A. Leckie. "Biography Matters: Why Historians Need Well-Crafted Biographies More than Ever". In Writing Biography: Historians and their Craft. Ed. Lloyd E. Ambrosius. Lincoln, NE:
} 
Contemporary critics of biography echo an older generation of historians and social scientists who felt unsure of the value of the biographical method. In his 1978 doctoral dissertation, Eric Arthur Gordon claimed, "It would be a most precarious history to try and generalize why a few native-born Brazilians also chose to associate themselves with anarchist ideas"6. Though I have tried to avoid generalizations by working my way up from the bottom, I have clung to the precipice of this 'precarious history' in offering a partial, condensed, and tailored version of the Leuenroth biography that seeks a dialogue with this exact question. I hope that others will answer the call and continue to research the life and motives of this inspirational man.

To the best of my knowledge, my biography of Leuenroth is thus far the longest, most detailed, and systematically organized available in English, despite the fact that it is only partial, though I cannot claim to have done this in the rigor that I would have liked. For example, I leave out what I consider immensely important biographical details in the construction of Leuenroth's ideological identity, such as an in-depth discussion of his family life, to say nothing of the fact that I end my biography in 1917, when Leuenroth is only 36 . The former is mostly due to the lack of availability of sources, while the latter has everything to do with scope. Let me address these two issues, of sourcing and of scope, briefly.

\section{Dilemmas of Biography: Lies, Silences, Sources and Scope}

When conducting a biography of an individual who has been dead for forty years, one encounters the feared dilemma of historians: achieving depth and breadth without

University of Nebraska Press. 2004. p. 1. Leckie makes an equally important argument, though not the one that I make in this thesis, that biographies are desperately needed for their ability to influence the general reading public.

${ }^{6}$ Eric Arthur Gordon. "Anarchism in Brazil: Theory and Practice". PhD Dissertation. Tulane University. 1978. p. 14 
sacrificing 'accuracy'. Sometimes the availability of sources allows the researcher to privilege one event or time period in an individual life while forcing them to 'silence' others. This is certainly true of my case. For example, Leuenroth was married in 1906 to Aurora da Costa Reis, and would ultimately have four children with her: Nilo, Nair, Germinal, and Anteu. Most of the information documenting these more personal aspects of Leuenroth's life only exists in letter collections contained in the Acervo Família Leuenroth, located in Campinas, São Paulo, to which I was not able to obtain access. Rather than introduce this extremely important aspect of his life in the main biographical narrative, I opted to leave it out, including the information only here in the introduction, except when discussing Leuenroth's family involvement in his professional and political activity. Thus, it is the silences that one needs to think about when reading biographies of any kind, not only what is portrayed on the page. It takes only a few moments to realize that, given the complexity of the human experience, the silences far outweigh the concrete statements in terms of available data, and thus any endeavor aimed at providing the whole 'truth' of an individual life is doomed to fail from the outset, and dishonest to claim it as such.

While some of my silences are intentional, decided in order to ensure narrative flow and construct a clear character, others are wholly unintentional, and some are unknown to me. Thus, my thesis must be used to complement those sources, or challenge them if need be. One such gap is Yara Khoury's doctoral dissertation entitled "Edgard Leuenroth, Uma Voz Libertária: Imprensa, Memória e Militância Anarco-sindicalista”, which she completed in 1989 at the University of São Paulo. After attempting to acquire this dissertation for close to four months, I was told that it was not possible to ship it to 
Canada. Thus, what doubtless would be an exceptional source for this project remains unavailable to me.

This explanation is not meant to waive responsibility for the information contained within these pages. I accept full responsibility for both their factual accuracies and inaccuracies, of which I am sure there are many. Yet there is something inherent in attempts at biography - whether critical or not - and in the expectations of the reader, that requires some sort of waiver for those who insist upon completeness and 'truth'. In my research, I have realized the futility of hoping to capture the unadulterated 'truth' of one's life. Part of this realization has been the outcome of a reflexive engagement with my subject of study: in comparing the incidents and experiences of my own life with those of Edgard Leuenroth, I quickly understood the indolence of claiming to represent the complexity of lived experience through text in a faithful manner. Though I began this project believing the contrary, I now feel there is an experiential component to human life that escapes linguistic representation.

However, there is a more basal problem with sources when working on a topic of this nature, one that I encountered repeatedly when writing the second chapter. Putting the silences aside, often it is the concrete facts that present the most problems for a researcher, author, and ultimately the reader. In many sources documenting various aspects of Leuenroth's life, there were repeated discrepancies and even contradictions between different authors on relatively straightforward factual data, such as the initial publication date for a periodical, or the profession of Leuenroth's father. Some of these discrepancies can be attributed to typographic errors, others to later sources repeating the mistakes of the earlier ones. Others likely highlight the peculiar ambivalence and 
unreliability of memory that any biographic testimony - whether direct from the subject themselves, or indirect from friends, family and colleagues - always brings out. Where I was aware of these issues, I have tried to bring them to light in lengthy footnotes so that the reader can pursue them further. Unfortunately for those recently introduced to the topic, many of the issues I have discovered have not been addressed yet in the secondary literature, a sign of the desperate need to expand this segment of Brazilian historiography and political economy.

This point brings me to a deeper, conceptual dilemma surrounding biography. Throughout this project, I struggled with balancing the level of objectivity and rigor that the social sciences and humanities demand, and what I view as a much 'truer' subjectivity that is extremely difficult to engage with in a scholarly manner. Throughout, I felt that I was not living up to the standards of 'objective' scholarship, and that it would be impossible to attempt to do so in good faith on a topic such as mine. I worried that what I define as the 'critical' component of my biography would be viewed as mere speculation that does not warrant inclusion into the scholarly literature.

Indeed, I worried about all of this until I came across an essay by Robert Skidelsky with the enigmatic title, "Only Connect: Biography and Truth". In it, Skidelsky seeks to justify biography as a legitimate scholarly enterprise, noting that it has never received such acceptance. After writing the majority of this introduction, I came across the sentence that put my whole endeavor into perspective,

...the modern biographer is equipped with sophisticated biographical credos: one can scarcely open a contemporary biography without reading, usually in the preface, a justification both for doing that particular biography and for biography in general?

\footnotetext{
${ }^{7}$ Robert Skidelsky. "Only Connect: Biography and Truth". In The Troubled Face of Biography. Eds. Eric Homberger and John Charmley. London, UK: The Macmillan Press. 1988. p. 2
} 
It was not a legitimate crisis contained within my scholarship that worried me, but how my own work, as a biography, related to the larger body of academia, since it was so nontraditional. In the process of writing this thesis, I have reaffirmed my belief that biography can tell us a lot about our world, both on a theoretical level and on the level of the human condition if it is shaped by an appropriate methodology, which I hope I have demonstrated in the pages that follow.

Biography cannot truthfully represent the immense complexity of an individual life, much in the same way that abstract theories can only provide a best guess for the existence of social phenomena. The problem is that traditionally people have often expected to find 'truth' in biographies, just as they hold certain theories up above critical scrutiny, and often biographers have made little or no effort to convince them otherwise. As readers, we expect order and rationality where often it does not exist, but simultaneously expect biographers to avoid speculation, to avoid constructing characters and their narratives, and engage in only 'factual' representations of their subject. As writers, we feel the pressure to 'stick to the facts', to only let our sources do the talking, despite our knowledge (perhaps late in coming for some) that the notion of the 'passive' scholar is an impossibility. Indeed, I have constructed a coherent narrative regarding the ideological formation of Edgard Leuenroth that appears rational, linear, and unified, generally conforming to these pressures, but I would be the first to caution against concluding that this is an 'accurate' representation of the struggles, tensions and ambivalences that Leuenroth faced in the process of his intellectual development. In most cases, as in that of Edgard Leuenroth, we just do not have the material to do this, but of course, even if we did, we would still be left with the problems of interpretation, 
arrangement, and phrasing. Victoria Glendenning has summed this up nicely, concluding that

Some readers [of biography] may seek for a final truth, and even find one - but that is their private adventure. All writers, whether of so-called fact or so-called fiction, are in the lies and silences business 8 .

The only difference with this thesis is that I want to reveal this up front: to embrace the character and what it can tell us about its environment in the hopes that constructive debates on what are essentially speculative matters on such subjective criteria as motive, meaning, desire, will - even reason - can occur?.

Philippe Lejeune states this in another way in On Autobiography,

I believe that we can promise to tell the truth, I believe in the transparency of language, and in the existence of the complete subject who expresses himself through it....but of course I also believe the contrary...telling the truth about the self, constituting the self as a complete subject - it is a fantasy.

It is obvious that this applies with even more murkiness to biography. Telling the 'truth' about someone else is an effort that will surely result in either failure, or a tightrope walk of authorial manipulation. Yet as Lejeune also says, "In spite of the fact that autobiography is impossible, this in no way prevents it from existing"10.

Rather than exclude it from legitimate social research, we need to conceptualize biography as an unparalleled tool for portraying the human experience at a particular level of abstraction, something that can complement structural analyses of social change, of ideological phenomena, of economies or polities. But we also need to throw off the shackles of an impossible demand for the truthful representation of subjectivity, and

\footnotetext{
${ }^{8}$ Victoria Glendenning. "Lies and Silences". In The Troubled Face of Biography. Eds. Eric Homberger and John Charmley. London, UK: The Macmillan Press. 1988. p. 49

${ }^{9}$ As an extreme example of this approach, Virginia Woolf brilliantly discusses gender discrimination in Shakespearean England through her construction of the fictional character of Shakespeare's sister, Judith. See Virginia Woolf. "In Search of a Room of One's Own" in The Norton Reader. Shorter $10^{\text {th }}$ edition. Eds. Linda H. Peterson et al. New York, NY: W.W. Norton \& Company. 2000. pp. 591-600

${ }^{10}$ Qtd. in Daniel James. Doña María's Story: Life History, Memory and Political Identity. Durham, NC: Duke UP. 2000. p. 119.
} 
embrace well-grounded speculation and argumentation, if we hope to strive for a much more nuanced conceptualization and understanding of that same human experience. If our biographies, as methodologies, are well thought out and appropriately scoped, then we are sure to gain clearer insight into the human condition. With these grand metatheoretical issues out of the way, let me explain the way I conceive of my method critical biography.

\section{Critical Biography as Concept and Method}

Many biographies, due in no small part to the amazing personal histories that they seek to express, do not get much past complex chronologies and series of anecdotes, resulting in 'flat' characterizations that do not actually tell us much about the person, or the social and environmental context in which that person existed. This is by no means a criticism of the research an author might put into their biography, or even an indictment of their writing, but rather of their methodologies. They claim to capture an individual life in its entirety with titles as grandiose as "The Complete Biography", yet consequently ignore the diverse factors that make up that individual life, factors that are overwhelmingly social and contextual.

One way to conceptualize this shortcoming is to think of a picture with the majority of the background cut out, so that only the subject of the photo and a few foreground items remain. How can we understand much about either that individual or their environment with the bulk of the context cut out? We need to embrace the 'negative space', the space around the subject of an image - or an individual - not as the only object of inquiry (as in structural accounts of social transformations), but as an integral complement to the 'positive space' that traditional biographies focus on. In other words, 
we need to work with more sincerity to connect structure and agents within our biographies.

Many biographies on political figures, for example, ignore how and why that figure came to adopt their political beliefs - biographers begin and focus their efforts on their ascent to power without situating that ascent in its appropriate historical and cultural context. Some authors are able to go farther (often in fewer pages) and develop more textured accounts that tell us what it was like to live in a certain time and place and just how those factors influenced the actions that individuals took part in ${ }^{11}$. I have aspired to such a textured biographical account of Leuenroth's life by scoping my thesis to address the question of his ideological identity formation.

In Contentious Lives, Javier Auyero points to a long tradition of "character construction" in ethnographic sociology aimed at understanding "the social dynamics of particular episodes or epochs", noting that "if constructed properly, characters can speak to larger issues"12. Though this is a perspective not always assumed by biographers, nor heralded by critics, biography is certainly about the construction of an individual life through the lens of another's - historical moment, cultural background, value suppositions included. Critical biography, then, is about the conscious framing of this life within the context of a broader social picture. It means we need to take responsibility for how we construct our characters (i.e.: how we scope and narrate our biographies), and pay close attention to the purpose they serve in elucidating the social contexts in which

\footnotetext{
${ }^{11}$ See for example, Barbara Weinstein and Daryle Williams "Vargas Morto: The Death and Life of a Brazilian Statesman" in Lyman Johnson, ed. Death, Dismemberment and Memory: Body Politics in Latin America. Albuquerque, NM: University of New Mexico Press. 2004. pp. 273-315. The short essay engages the death and final years of Gétulio Vargas in a way that brings out some of the deeper currents of his time and place.

${ }^{12}$ Javier Auyero. Contentious Lives: Two Argentine Women, Two Protests, and the Quest for Recognition. Durham, NC: Duke UP. 2003. p. 207.
} 
they are situated. Critical biography requires that we reject the assumption that we can objectively portray the complete lived experience of an individual, while simultaneously embracing the recognition that our biographies need to account for the embeddedness of the individual in their social and environmental circumstances.

Thus if we are to consciously think about it for a moment, why should we give the individual primacy throughout our biographies if our purpose is also to gain a better understanding of a particular historical moment? We should not use the individual as the only category of analysis when conducting biographies ${ }^{13}$. Hence, I resisted organizing this thesis into chronologically based chapters documenting Leuenroth's life that would discuss the relevant background for that time and place within each, ultimately oriented around Leuenroth as an individual, as traditional biographies usually do. Instead, I sought to look at a different level of abstraction in each chapter. In the first chapter, I privilege the theoretical realm of 'the idea' as my central unit of analysis in relation to Leuenroth's life. I relate distinct ideas on politics, society and economy to his ideological understanding of anarchism, and craft a framework by which we can apply that ideology to his personal biography. In the second chapter, I privilege the individual as the central unit of analysis, focusing on the intellectual, activist and professional development of Edgard Leuenroth. In the final chapter, I privilege the structural aspects of social life in Brazil, exploring a number of broad circumstances and shifts that I feel were conducive to the rise of anarchism in the country, and especially in the state of São Paulo where Leuenroth lived. I bring in experiences from Leuenroth's life when relevant in the

\footnotetext{
${ }^{13}$ Of course, this is a limitation implicit in the definition of biography. However, we must remember (though it is often forgotten) that the individual life is not of particular interest for scholarly study, except in that it helps define a context in more detail through its relation to certain ideas, events, actions, and struggles.
} 
discussion to help the reader understand the larger structure by using examples from the life of one agent within that structure.

Thus, critical biography as the method that I have utilized is about nesting different levels of abstraction in order to obtain a fuller picture of the entire social landscape that the subject of the biography lived within. It often means sacrificing the attempt to document the complete life experiences of the individual, as length is a concern, though as I have argued above, we should discard this problematic notion and focus our efforts on well-scoped argumentation and speculation in the hopes that we can open up new insights on people's times and place. However, it enables a deeper understanding of the complexities of the individual's lived experience that traditional biographies cannot offer.

\section{Looking to the Future: Variations of Critical Biography}

I wanted to think broadly about Leuenroth's ideological identity formation, taking a number of factors into account. As a result, I merely introduce many potential factors that need to be explored in theoretical depth much more ${ }^{14}$. Two previously ignored factors in the field of biography that could contribute to our understandings of social context are the social psychological and the ecological. The first could explore, in more detail than I have done, the meaning that Brazilian anarchists made from their involvement in social activity. By integrating intellectual currents and symbols of socioeconomic relations with theories of cognitive processing, we would get a glimpse into a little studied area of the human experience. For example, Leuenroth's activity in the first Congress of the Confederação Operária Brasileira (COB) in 1906 marked what we could

\footnotetext{
${ }^{14}$ Namely, the mechanisms by which tangible experiences are processed into individual ideological identities, for which I did not have space to address in Chapter 1. For now, we must rely on the relevant social psychological literature, a sample of which I include in the next chapter.
} 
view as an integral moment in his development as a political organizer. A sustained analysis of the COB and Leuenroth's personality attributes using the theory of symbolic interactionism might help us better understand the dynamics of the anarcho-syndicalist movement in early twentieth century Brazil ${ }^{15}$. The second could explore the way that ecological and geographical relationships, in terms of both physical and social spatialization, influence the formation of identity and values ${ }^{16}$. For example in Brazil, massive urbanization drastically altered how individuals conceived of themselves and their nation, but those who came from a rural or semi-urban setting would have had a different socialization (or environmentalization) that shaped their subsequent social and psychological development. Though I only mention these factors in Chapter 1 and give a brief discussion of them in relation to Leuenroth's life in the second Chapter, I hope that future scholarship will take these up as integrated facets of individual ideological identity construction, and in relation to identity construction more broadly.

\section{Thesis Outline}

Chapter 1, entitled "The Production of Ideological Identity: Conceptualizing the Anarchism of Edgard Leuenroth" positions the level of theory at the fore, with the 'idea' as the central unit of analysis. It begins by laying out the ideological landscape with a brief definitional discussion on the historical development of anarchism. From there, it focuses on the political, social and economic underpinnings of Edgard Leuenroth's anarchism in some detail, which serves as an anchorage point for the following chapter. It then briefly picks apart and defines 'identity' and 'ideology', and seeks to relate these

\footnotetext{
${ }^{15}$ For more on how we might apply symbolic interactionism, see Herbert Blumer. Symbolic Interactionism: Perspective and Method. Berkely, CA: University of California Press. 1969.

${ }^{16}$ For an interesting non-academic example of how this might look, see Ernesto Che Guevara. The Motorcycle Diaries: Notes on a Latin American Journey. New York, NY: Ocean Press. 2003.
} 
two concepts to one another. Finally, returning to a broader perspective, it schematizes a number of factors that contribute to the formation of ideological identity, and gives a brief example of their application to Leuenroth's life, in anticipation of the next chapter.

The second chapter, entitled "Edgard Leuenroth: Formation and Growth, 18811917 " begins in the town of Mogi-Mirim in 1881, the year of Leuenroth's birth, and tries to contextualize his life experiences with the wider social fabric of the times. Partly in lieu of accessible sources on Leuenroth's early life, it explores the way historical and cultural tropes of the state of São Paulo provided a conducive atmosphere for philosophies embedded in individual liberty to flourish, examines the urban geography of the town to tease out the environmental impacts on Leuenroth's life, and looks at how the socio-economy of the region structured the range of thinkable possibilities for the organization of social life. I do not seek to provide definitive answers through my case study for the roots of Leuenroth's ideological identity. Rather, I seek to begin a dialogue on the 'negative space' that outlines all of our lives in the hopes of encouraging other scholars to think much more broadly and critically about where our beliefs come from. The chapter continues along this path, charting Leuenroth's life course as he develops from a young office boy and assistant shopkeeper to an accomplished typographer, journalist and organizer. I end Leuenroth's life prematurely, long before his death at the age of 87 in 1968, in 1917, with his release from prison after the General Strike of São Paulo, of which he was labeled the 'mastermind'. This was done in order to define an appropriate scope for the thesis, though I also felt that there is considerably more information about Leuenroth's later life circulating in English than there is regarding his earlier 'formative years' that an interested reader could track down. 
The third chapter, entitled "The Structural Origins of Anarchism in Brazil" looks at some of the formative structural factors that led to the very sudden growth in anarchism in Brazil in the mid 1880s. I explore the effects of mass immigration, transitional industrialization and urbanization, class dynamics, the nature of the Old Republican State, and culture and nationalism, as determinants in the rise of anarchist ideology. The purpose of this is to provide a 'macro' perspective to the 'micro' and 'meso' of the previous chapters. I also relate the broader trends back to the individual experiences associated with Leuenroth's biography described in Chapter 2, in order to form contextual links between structure and agents.

Finally, I conclude with an exhortation for future scholarly inquiry on this inspiring figure, and on the topic more generally. I address the extremely understudied issue of 'race' in relation to Brazilian anarchism and the labor movement, highlighting potential avenues for future scholarship before providing a brief summary of my arguments. 


\section{Chapter 1: The Production of Ideological Identity: Conceptualizing the Anarchism of Edgard Leuenroth}

What might make an individual identify with anarchist beliefs for their entire life?

What might drive them to actualize those beliefs as a key component of their daily identity, articulated through the tangible devotion to them through activism and professional commitments? Moreover, why might they do these two things when the consequences for identifying themselves as an anarchist, and certainly for actively pursuing values associated with anarchism, were considerably harsher than conforming to the standard expectations of the status quo? These questions do not seem to be too complicated, but they contain layers of complex assumptions and caveats that we need to enunciate in order to deconstruct the logic of the highly subjective meaning-making process that ideological identity formation entails.

This chapter cannot answer all of these questions or spell out all of these necessary assumptions, but it does try to get us to a point where we can begin thinking about how individual ideological identities are formed. It will start by situating Edgard Leuenroth's specific ideological beliefs within the broader spectrum of philosophy and praxis called 'anarchism', going on to explain the details of the beliefs that Leuenroth held, typified in their mature manifestation in a 1963 book entitled Anarquismo: Roteiro da Libertação Social. From here, it will define the concepts of 'ideology' and 'identity' in accordance with the ways I use them, and offer a basic schema for how to think about ideological identity formation. Finally, in reference to the factors contained within the schematic, it will offer an introduction to some of the arguments explored in Chapter 2. 


\section{Anarchism: A Philosophy and Praxis against Arbitrary Power}

The branch of thought dubbed "anarchism" is actually a collection of diverse and varied strands of beliefs and practices that, when broken down to reveal their defining features, often seem much more distinct than they are similar. As a result, much of the writing on anarchism spends a lot of time asking and answering just what it is. As George Woodcock begins his seminal text Anarchism, "Few doctrines or movements have been so confusedly understood in the public mind, and few have presented in their own variety of approach and action so much excuse for confusion" ${ }^{\text {"17 }}$. So then what, in simple terms, though Woodcock cautions us against simplicity, is a useful working definition for this complex and fluid ideology?

Woodcock points out that "Historically, anarchism is a doctrine which poses a criticism of existing society; a view of a desirable future society; and a means of passing from one to the other" ${ }^{\prime 18}$. Yet this working definition of anarchism applies to almost all political ideologies and their proponents. Few distinctive aspects of a future anarchist social vision are the same across the different branches of the ideology, and their critiques of the existing society sometimes seem more confrontational than allied with one another. That said, the one defining characteristic across all anarchist philosophies, I would posit, is a rejection of 'arbitrary' power. The 'arbitrary' caveat is warranted because just what constitutes coercive power differs across time, place, and thinker.

For example, anarcho-capitalism as envisioned by American economist Murray Rothbard sees arbitrary power in the form of the state and social ties that limit individual action, but embraces the property rights and the unequal wage relation that Pierre-Joseph

\footnotetext{
${ }^{17}$ George Woodcock. Anarchism. Peterborough, ON: Broadview Press. 2004. p. 11

${ }^{18}$ Ibid.
} 
Proudhon saw as utterly coercive ${ }^{19}$. Bakunin, speaking in a European context, vociferously detested the concept of 'God' and the religious institutions that the Church elaborated for itself, designing his critique around the contrast between idealist and materialist understandings of the world ${ }^{20}$. Others, such as Leo Tolstoy and Ammon Hennacy argued that the only single authority over humanity is that of God, and that its dictates require a literal interpretation of the Bible that would lead to a society where government, violence and class struggle did not exist ${ }^{21}$.

Yet another sharp divide has Max Stirner valuing egoistic individualism above any social compact. According to Daniel Guérin, Stirner often concluded that life in society was impossible, though he actively pursued community involvement ${ }^{22}$. In his book The Ego and His Own, Stirner proclaimed in response to Marx's exhortation that we respect our peers, "As far as I am concerned, no one is deserving of respect, not even my peers" ${ }^{\text {,23 }}$. In contrast, Peter Kropotkin seeks to spell out the 'real' brilliance of Darwin in his book Mutual Aid by showing that cooperation is the cornerstone of evolution in the natural world, not competition, and that human evolution is deeply interwoven with this practice.

It is the unconscious recognition of the force that is borrowed by each man from the practice of mutual aid [of human solidarity]; of the close dependency of everyone's happiness upon the happiness of all; and of the sense of justice, or equity, which brings the individual to consider the rights of every other individual as equal to his own ${ }^{24}$.

\footnotetext{
${ }^{19}$ For a detailed exposition of his positions, see Murray Rothbard's gargantuan work Man, Economy, and State with Power and Market. Scholar's Version. Auburn, AL: Ludwig Von Mises Institute. 2004. For Proudhon's critique of private property, see. What is Property? McLean, VA: Indypublish.com; No Date. ${ }^{20}$ Michael Bakunin. God and the State. New York, NY: Dover. 1970. p. 13

${ }^{21}$ See Leo Tolstoy. The Kingdom of God is Within You. New York, NY: Dover. 2006; Also, Ammon Hennacy. The Autobiography of a Catholic Anarchist. New York, NY: Catholic Worker Books. 1954. ${ }^{22}$ Daniel Guérin. No Gods, No Masters: An Anthology of Anarchism. Oakland, CA: AK Press. 2005. p. 10

${ }^{23}$ Qtd. in Ibid. p. 24

${ }^{24}$ Peter Kropotkin. Mutual Aid: A Factor of Evolution. New York, NY: Dover. 2006. p. xvi
} 
Closer to the core divide that separated the different anarchist actors in the Brazilian movement, there are those who favor anarcho-syndicalism, which focuses its efforts on uniting and educating the working class through direct action, and views the trade union federation as the central mechanism leading to their ultimate goal of the destruction of capitalism ${ }^{25}$. That anarcho-syndicalism, due to its historical origins, is centered on workers and workplaces, often in industrial settings, has provoked criticism on the part of anarcho-primitivists - a relatively recent manifestation finding prominent expression in the work of Derrick Jensen and John Zerzan. Drawing upon long-held critiques of 'civilization' itself, they contend that the urban industrial conditions that anarcho-syndicalism seem to take for granted, are inherently oppressive ${ }^{26}$. Writing with the Brazilian context in mind, Edgar Rodrigues has distinguished anarchism as "the action of individuals who... [seek] the establishment of a New Social Order which is horizontally decentralized and self-managed", while anarcho-syndicalism "takes the worker as the basic cell of society striving to complete his development". What distinguishes the two, according to Rodrigues, is method: anarchism "reaches as far as freedom and intelligence can reach", while "Syndicalism is...geared more to the administration of production and consumption"27.

Thus, it is clear that the relative notions of what constitutes arbitrary power by many who call themselves 'anarchist', limit our ability to make concrete statements about what balance between individuality or collectivity a generically 'anarchist' social vision

\footnotetext{
${ }^{25}$ See Rudolf Rocker. Anarcho-Syndicalism: Theory and Practice. Oakland, CA: AK Press. 2004.

${ }^{26}$ See Derrick Jensen. Endgame, Volume 1: The Problem of Civilization. New York, NY: Seven Stories Press. 2006; John Zerzan. Future Primitive: And Other Essays. Brooklyn, NY: Autonomedia. 1994. Though the vision depends on the branch of anarco-primitivists in question, most support a pre-industrial revolution society.

${ }^{27}$ Edgar Rodrigues. "A History of the Anarchist Movement in Brazil”. In Against All Tyranny! Essays on Anarchism in Brazil. Ed. Paul Sharkey. Berkeley, CA: Kate Sharpley Library. 2003. pp. 2-3.
} 
would actualize, or where we should draw the line between what we might consider "spiritual laws", and those that are imposed by human design. Anarchism, then, is a meeting place where those who struggle against orthodoxy can vent their frustrations, carving out a life that values the ideals that they hold true. However, it is not my intention to detail all of the conversations that those intellectual wanderers have at their meeting place $^{28}$. Instead, it is to explain how one individual fits into all of this. Let us turn to the ideals that Edgard Leuenroth would espouse and aspire to, best represented in his own anthology, Anarquismo: Roteiro da Libertação Social.

\section{Principle and Praxis: The Anarchism of Edgard Leuenroth}

Like many anarchists before him ${ }^{29}$, Leuenroth felt it necessary to publish his guidebook on anarchism in 1963 because the "effervescence" of the times called for a redefinition of anarchist principles ${ }^{30}$. Responding to the glut of high-brow intellectual work in Brazil on the 'social question', or works embracing a socialism "strangled by the hindrances of a false nationalism", Leuenroth wants to know what, in the end, anarchism is, noting that even those who are educated often ask the very same question ${ }^{31}$. The book opens with a synthesis of anarchism, including the "General Principles of Anarchism" by Errico Malatesta, and an excerpt from George Woodcock's book, The Basis for Communal Living, before going on to outline the positions of the Brazilian anarchists, including his own.

\footnotetext{
${ }^{28}$ For this, see one of the many anthologies of anarchism, such as Daniel Guérin. No Gods, No Masters: An Anthology of Anarchism. Oakland, CA: AK Press. 2005; Robert Graham. Anarchism: A Documentary History of Libertarian Ideas. Montreal, PQ: Black Rose Books. 2005; or George Woodock's solid survey, Anarchism. Peterborough, ON: Broadview. 2004.

${ }^{29}$ See for example, Alexander Berkman. The ABC's of Anarchism. New York, NY: Dover. 1972.

${ }^{30}$ Edgard Leuenroth. Anarquismo: Roteiro da Libertação Social. Rio de Janeiro: Editôra Munda Livre. 1963.p. 3

${ }^{31}$ Ibid. p. 4
} 
Leuenroth forcefully captures what he views as the essence of anarchism in a long, but vivid quote:

\begin{abstract}
We don't know how [anyone], in good faith, can affirm that anarchists can offer happiness to the famished by the year 2000. We must say that those who judge us thusly are absolutely wrong and we clarify why. The anarchists, as well as asking for nothing, offer nothing, because they do not present themselves as messiahs, as leaders, as mentors or demagogue politicians who promise this world and the next in order to elevate themselves to the heights of government. Libertarians espouse an ideal that advocates the substitution of the current society, characterized by iniquity, exploitation and tyranny, for another, based on the principle of social equality. And, convinced of the justice of this ideal, they fight for it, spreading it everywhere, at the same time that they fight with the [same] people to whom they belong to in the claim of their rights, subjecting themselves to all the consequences of this fight ${ }^{32}$.
\end{abstract}

Beyond Leuenroth's interchangeable use of anarchism and libertarian, two things are clear in this espousal of anarchism. First, according to Leuenroth, anarchism is processbased rather than utopian, in the sense that it does not provide a static conception of a social reality that merely requires implementation. At the beginning of the book, alongside one of his own articles arguing the same thing, Leuenroth excerpts a short paragraph by Luce Fabbri, the eminent Italian anarchist writer and publisher that tries to lay the question to rest: "Is anarchy utopia? Everything that is human is utopian before becoming reality; and everything that depends on human will is realizable",33.

Thus, for Leuenroth, any social vision depends on the struggles and efforts of humanity to achieve it. As a collectivity, whatever we humans put our minds to is achievable, but the catch is that any goal is contingent on the consciousness and action of all. Thus, Leuenroth takes a swipe at Marxists and social democrats by criticizing their propensity to make promises in exchange for votes because he believes that it cannot be a vanguard, a class of people, or a group of intellectuals that can bring about true social equality, but rather must be the entire society itself. Fabbri sums this up in a

\footnotetext{
${ }^{32}$ Ibid. p. 28-9

${ }^{33}$ Ibid. p. 14
} 
straightforward fashion, "Utopia is to want to manufacture a society from the top of the government, using men as raw material, by force of laws applied because of a [predetermined] vision" 34 .

Second, Leuenroth reifies a certain ethos that must make up the core persona of the anarchist. Anarchists must be activists as well as intellectuals. They must demonstrate the willingness to engage in public discourse in order to push for the ideals that they believe in, not be content to sit on the margins of society, in the universities or in the cafés discussing theories of class-consciousness that attempt to explain why the proletarian have not risen up yet and taken their position as a class for themselves. After all, Leuenroth points out that given all the efforts of the anarchists, they do not want to replace the dictatorship of the capitalists with the dictatorship of the proletariat ${ }^{35}$. Thus, there is a form of praxis implicit in Leuenroth's understanding of anarchism. Upon coming to 'know' certain value propositions, one must synthesize that knowledge with practice and action aimed at achieving them. Knowledge, or education, is necessary alongside practice, if an accurate and effective campaign for social revolution is to be waged.

Hence, Leuenroth believed firmly in "direct action" over indirect means of transforming society, such as the formal political processes ${ }^{36}$. He lambastes parliaments for being inefficient, unable and unwilling to make laws actually work in favor of the

\footnotetext{
34 Ibid.

${ }^{35}$ Ibid. p. $70-1$

${ }^{36}$ Though it is just beyond the scope of the biography in the next chapter, it is useful to note that in the aftermath of Leuenroth's legal fiasco resulting from the accusation that he was the mastermind of a general strike in São Paulo the year before, his name was presented by Ambrogio Chiodi, along with the signatures of over 200 hundred socialist workers as a candidate in the federal election of March 1918. Leuenroth refused to accept, explaining that this went against his core beliefs. See Dealbar, p. 1; Luigi Biondi. "Desenraizados e integrados: Classe, etnicidade e nação na atuação dos socialistas italianos em São Paulo (1890-1930)”. Nuevo Mundo Mundos Nuevos. 12 March 2007. p. 28, fn. 25.
} 
people, and beholden to the interests of capital, and instead advocates that people get used to doing things for themselves, without guidance or leaders ${ }^{37}$. This belief in individual responsibility weighs strongly in Leuenroth's vision of anarchism, since he sees this principle as one of the key tenets in his social vision. An excerpt of an article published by his close friend, João Pentado and others, entitled 'Education and Teaching', captures Leuenroth's perspective very succinctly: "Liberty, responsibility, and selfdiscipline characterize the formation of the human personality in accordance with the fundamental concepts of anarchism,"38.

Thus far, we have a reasonable understanding of the social and political side of Leuenroth's anarchism, but how does he treat economics? Quite possibly the most powerful public arguments that Leuenroth made throughout his life, but inextricable from the rest of his anarchism, were anti-capitalist in nature ${ }^{39}$. Leuenroth saw his own beliefs falling under the umbrella of 'socialism', though he is careful to disaggregate this definition from the meanings with which it has come to be associated. He calls for the socialization of all property, and then explains that one can organize the production, distribution and consumption of society according to either communist or collectivist logic. Citing Kropotkin, he explains that historically anarchists have flocked to collectivism because Marxists had usurped the title of communism, and imbued it with the idea of a strong centralized state ${ }^{40}$.

\footnotetext{
${ }^{37}$ Leuenroth. Anarquismo, p. 57-8

${ }^{38}$ Ibid. p. 208

${ }^{39}$ It is for this reason why Leuenroth was approached by a representative of the Third International sometime in the winter of 1921 asking him to form the Brazilian Communist Party. See John F.W. Dulles. Anarchists and Communists in Brazil, p. 162-64; also Edgar Rodrigues. Nacionalismo \& Cultura Social, p. 403-6.

${ }^{40}$ Leuenroth. Anarquismo, p. 76
} 
Leuenroth concedes that there are "diverse modalities" of anarchist economics, ranging from anarcho-communism to anarchist individualism rooted in collectivism, though he explains that the individualist and collectivist strands have declined greatly because of the inherent limitations on their practicability ${ }^{41}$. In the end, he sides with the 'anarcho-communist' current, explaining, "we need the abolition of exploitation of man against man through the socialization of property and the destruction of regimes of competition in the systems of production and distribution, facilitated by the use of money"42. From this, we would get what Leuenroth says he has always advocated as the maximum aspiration of anarchism: "the expansion of the amount of free time for the individual, as a social unit in conviviality of their community, brought about by the basic human principle of mutual support" ${ }^{43}$.

Leuenroth sought to put this conception of anarcho-communism into practice with his life-long involvement in various anarcho-syndicalist organizations, some of which are described in the following chapter. As a result, he spent much of his time focusing his struggle for social equality on the specific plight of workers toiling under industrial capitalism $^{44}$. Some might explain this away as a distinction between pragmatism and idealism, yet this might be slightly misleading. Leuenroth spent much of his time writing and making forays into public discourse not only on behalf of the 'bread and butter'

\footnotetext{
${ }^{41}$ Effectively, Leuenroth points out that given human dependence on a variety of tools in the provision of our personal provender, fulfilling the maxim of collectivism, "to each according to his work", would require us to draw upon the tools and inventions of all those who have preceded us - not all of which would be freely given. Ibid. p. 77

${ }^{42}$ Ibid. p. 78

${ }^{43}$ Ibid.

${ }^{44}$ This has drawn criticism by some scholars such as Joel Wolfe who points out both the 'misogyny' and the negligence of anarchist activists like Leuenroth when it comes to their treatment of household labor, or even female involvement in the workforce. See Joel Wolfe. Working Women, Working Men. Durham, NC: Duke UP. 1993. One can certainly see some of this in both Leuenroth's writings in his contemporary contexts and later in his life (Anarquismo, 108), however, one can also see moments when he explicitly addresses patriarchy and the sexual division of labor (Anarquismo, 14, 204-7)
} 
issues affecting workers, but also in support of more abstract ideals such as those described above. That much of Leuenroth's social experience growing up in a working class neighborhood revolved around industrial labor - for women and children as well as men - might explain this intense focus. Moreover, while Leuenroth advocated for bread and butter issues such as increased pay and the regularization and shortening of the working day, he never claimed that these should take precedence over the larger questions of capitalist and state domination. Indeed, Leuenroth saw anarcho-syndicalism as the initial step within the larger social struggle for anarchist ideals, not as something separate or contrary to it. Thus, strikes represented the most pertinent form of direct action, a resolution to the immediate and tangible issues affecting the majority of people in the social reality of the working class neighborhoods of São Paulo.

Figure 1.1: "Fundamental Synthesis of the Bases of Anarchism"45 SINTESE FUNDAMENTAL DAS BASES DO ANARQUISMO

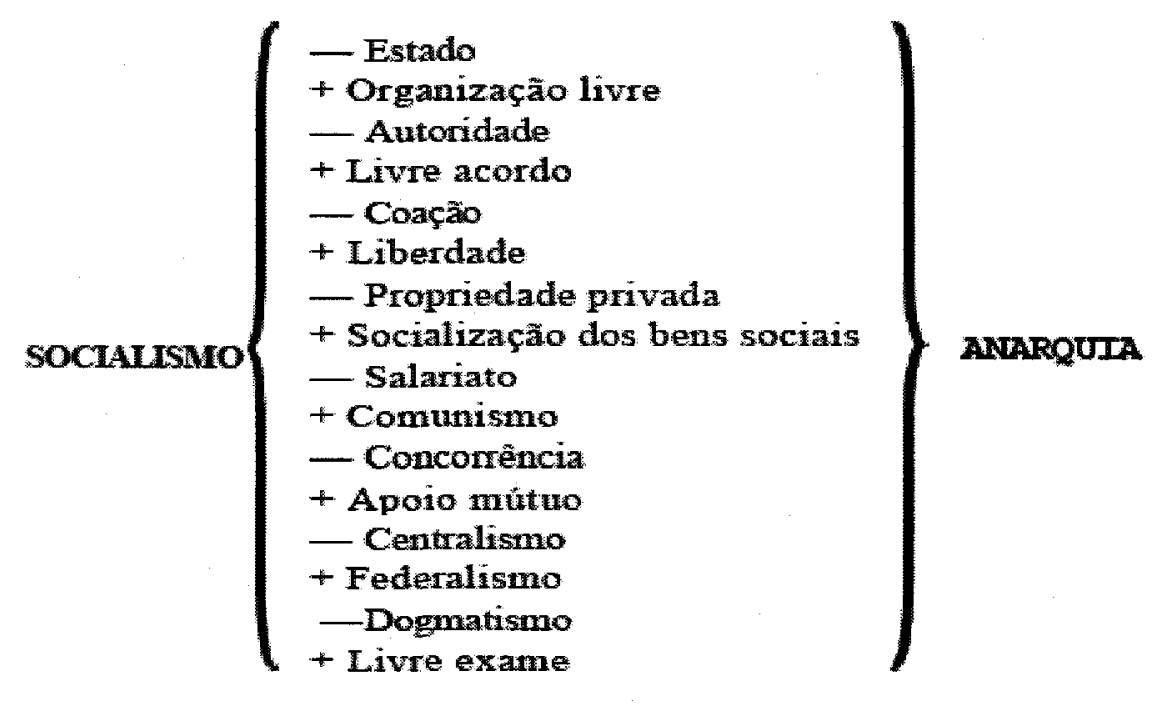

${ }^{45}$ Tenets that connote negative values in Leuenroth's anarchist social vision are denoted with a '- - , while the positive tenets are marked with a ' + '. Leuenroth cautions us that the positive tenets expressed here are primarily those in accordance with anarcho-communism, due to the ease of their expression (and likely because they were the ones he believed in). Reproduced from Edgard Leuenroth. Anarquismo: Roteiro da Libertação Social, p. 80 


\section{Intersections: Biography, Ideology, Identity}

Taken together Leuenroth's beliefs form a coherent and mature conception of anarchism, though more recent theorization has challenged some of the essentialist positions of early twentieth century anarchists, added subjectivist accounts to what, following writers such as Bakunin and Malatesta, were virulently materialist approaches to anarchism, and complicated notions of 'power' that had often been flatly characterized ${ }^{46}$. The central question that this thesis tries to answer is how he arrived at and maintained these beliefs. What ultimately drew a young provincial boy from interior São Paulo to adopt and develop a set of relatively marginal beliefs that he would vociferously advocate throughout his entire adult life?

There is nothing inherent in anarchist biographies, in and of themselves, that can comfortably answer this question. Some of the most influential anarchists came from quite different backgrounds. For example, Peter Kropotkin was a Russian prince born in Moscow who traveled throughout Siberia with the military before spending much of his life living in England ${ }^{47}$, while Pierre-Joseph Proudhon was born in a suburb of Besançon, the son of a poor journeyman brewer and a domestic servant, who struggled to quench his thirst for knowledge ${ }^{48}$. Some similarities between Leuenroth and these two lend themselves to interest: the fact that Proudhon worked as a proofreader and publisher, a career quite close to that of Leuenroth, or that the cousin of Leuenroth's maternal grandmother was the Viscount of Rio Claro, yet this is not enough for us to conclude definitively that one occupation, circumstance, or life experience spurred interest in

\footnotetext{
${ }^{46}$ For a good summary of the recent developments in anarchist thinking, see Michael Galvin's book review, "Power, Subjectivity, Resistance: Three Works on Postmodern Anarchism". New Formulation. Vol 2, No. 2. 2004.

${ }^{47}$ Peter Kropotkin. The Conquest of Bread and Other Writings. Ed. Marshall S. Shatz. New York, NY: Cambridge UP. 1995. pp. vii-xxvi.

${ }^{48}$ P.J Proudhon. What is Property? McLean, VA: Indypublish.com. n.d. pp. iv-v
} 
anarchist beliefs. People's individual ideologies are far too subtle and complex to be accounted for in a short two-sentence biographical description. Ideologies are multisourced because they are multi-faceted; they have ramifications for the whole of an individual's social life, in all of its 'distinct' manifestations, and therefore are constructed from this variety of the social experience (see Figure 1.2, p. 33).

Let me take a moment to define the way I use ideology throughout this thesis, given the historical baggage that comes with the term. I want to think of ideology simply as a collection of diverse ideas that form a relatively coherent whole (though not necessarily totalizing or free of contradictions) $)^{49}$. I want to put aside Marxist notions of dominant ideology as a tool used for social reproduction by the bourgeoisie for a moment and assert that all iterations of language gathered into coherent webs, all systems of knowledge, are ideological in the sense that they all advance certain value propositions contained within ideas. Thus, Marxist-Leninism, Anarcho-Syndicalism, and NeoLiberalism, according to the way I think about ideology, are effectively the same, in that they advance a relatively coherent vision of how to interpret social reality in accordance with certain truth claims.

My intention is not to grapple with the power relations between these different ideologies in this thesis, nor is it to reify a particular one in these pages ${ }^{50}$. Indeed, I want to reject conceptions of ideology that view it through the lens of traditional Marxist false consciousness, through which specific class interests are projected as universal human

\footnotetext{
${ }^{49}$ The way I use 'coherence' here is akin to Laclau and Mouffe's conception of how 'floating signifiers' are fixed into an ideological field via 'nodal points', what they refer to as 'articulation'. Laclau and Mouffe. Hegemony and Socialist Strategy, 112-4. For a more lucid overview of this process as it relates to ideology, see Žižek. The Sublime Object of Ideology, 87-9.

${ }^{50}$ Though, given that ideologies are ever-present and inescapable, it is only natural that I do my own privileging of a specific ideology within these pages.
} 
interests $^{51}$, as well as those following Deleuze and Guattari, who proclaim, "there is no ideology and never has been" ${ }^{, 52}$. One might say that I want to invert what Deleuze and Guattari say by claiming that 'there is only ideology, and always will be'. We all participate in the perpetuation of particular ideologies through the articulation and actualization of our beliefs and our attempts to share them with others. Any critique of 'ideology' (implying falsity) necessarily asserts an oppositional truth - what it is that people are actually doing when they do not know that they are doing it, to use Žižek's awkward phrasing ${ }^{53}$. While I laud the process of ideology critique as necessary and effective, my purpose in this thesis, revolving around how and why Leuenroth came to form and act upon his ideological beliefs, is different. Thus, I use the term 'ideology' throughout this thesis as a placeholder to account for the particular catalogue of beliefs, values and ideas that formed such an important part of Leuenroth's identity ${ }^{54}$.

Accounting for where these beliefs come from or what they mean to their purveyors is an extremely difficult task. Yet this does not preclude us from seeking to highlight certain factors, incidences and experiences - recognizing their potentiality that help us understand the logic behind individual beliefs. For example, there is something in the fact that so many anarchists were born in the $19^{\text {th }}$ century, when capitalism was developing into a totalizing force, and when struggles for liberty, both colonial and metropolitan, were ramping up throughout Europe and the Americas that might lead us to examine the role that global communication networks played in their

\footnotetext{
${ }^{51}$ Slavoj Žižek. The Sublime Object of Ideology. New York, NY: Verso. 1989. pp. 49-50

${ }^{52}$ Gilles Deleuze and Felix Guattari. A Thousand Plateaus: Capitalism and Schizophrenia. Trans. Brian Massumi. Minneapolis, MN: University of Minnesota Press. 1987. p. 4

${ }^{53}$ Slavoj Žižek. The Sublime Object of Ideology, p. 28

${ }^{54}$ That this definition of ideology is quite broad and unwieldy is mitigated by the fact that Leuenroth identified with 'predefined' ideological strands that he called, often interchangeably, anarchist or libertarian. Above, I have tried to spell out the details of that ideology in summary form to outline what ideas and value propositions it advances.
} 
formation. However, these factors need to be placed in their appropriate social contexts when we seek to apply them to specific personalities. Thus, my accounting of Leuenroth's ideological beliefs is neither definitive, nor are the factors that I choose to highlight necessarily applicable to the biographies of other anarchists. Getting back to that original question, let me first explain what I mean when I use the term 'identity'.

Identities are fundamentally social. As Habermas points out, an identity "can be secured only by means of interpersonal relationships; it stands and falls with the 'recognition' it finds - be it at the cross-cultural or international level or at the interpersonal level among friends and family, and so on" ${ }^{\text {"55 }}$. However, identities are more than just social, as George Herbert Mead recognizes, when he says,

While minds and selves are essentially social products, products or phenomena of the social side of human experience, the psychological mechanism underlying experience is far from irrelevant indeed is indispensable - to their genesis and existence... 56

Indeed, there are myriad factors that we need to consider when thinking about identity formation, negotiation and perseverance. Just as, in one way or another, ideologies are derived from, and manifest themselves, in every facet of our experience, identities are composed from our complex web of interactions with our time, place, environment (social and otherwise), and selves. If the sources of our identities are incredibly diverse and varied, the mechanisms that lead to our identification with certain concepts (e.g.: 'black', 'straight', 'lawyer') are even more so. Even with seemingly fixed categories of identity such as 'sex', maintained by deeply rooted social mores and complex systems of scientific knowledge translated into lay terms, the diversity of identifying and identifying

\footnotetext{
${ }^{55}$ Jürgen Habermas. On the Pragmatics of Social Interaction: Preliminary Studies in the Theory of Communicative Action. Trans. Barbara Fultner. Cambridge, MA: The MIT Press. 2001. p. 156; See also Richard Jenkins. Social Identity. London, UK: Routledge. 1996; Ian Craib. Experiencing Identity. London, UK: Sage. 1998.

${ }^{56}$ George Herbert Mead. Mind, Self and Society: from the Standpoint of a Social Behaviorist. Chicago, IL: University of Chicago Press. 1934. p. 1-2.
} 
with categories such as 'male' and 'female' are fantastic ${ }^{57}$. What one person views as an inherent biological category is seen as completely socially constructed by another, even when the same language is being employed ${ }^{58}$.

Thus identities are formed, produced and maintained through a constant dialogical negotiation between external-social sources of identification and cognitive and psychological tools for interpreting, processing and subsequently articulating the identity in question ${ }^{59}$. Some of these factors will forever escape linguistic representation, such as the emotive and expressive experiences that we encounter and internalize in a single moment, in many cases unconsciously. For example, from the standpoint of the biographer, we are unable to discern the unconscious effects of the internalization of a single racist joke by a subject who laughed at it in the formation of their identity as an anti-Semite. Even if we are aware, as scholars, of a pivotal emotional experience in the formation of an individual's identity, we still face the task of trying to explain its significance through our own frame of reference, saddled with all of the biases and beliefs that make up our own identity.

However, the purpose of drawing attention to the pitfalls that connects biography and identity is not a caution to limit inquiry, but quite the opposite. We need to broaden the way we think about individual identity construction, and the factors that form the building blocks of identity. Rather than shy away from speculation, we need to push this,

\footnotetext{
${ }^{57}$ More recently, the catchall term 'intersex' has been employed to apply to the plethora of biological identities that exist relating to the reproductive organs of the body.

${ }^{58}$ On the sex/gender distinction, see Joan W. Scott. Gender and the Politics of History. New York, NY: Columbia UP. 1999. pp. 199-207

${ }^{59}$ I lament not being able to elaborate the mechanisms more fully, but as stated in the introduction, due to time and length constraints, I can only refer the reader to some of the more general literature. See Petra Hauf and Friedrich Försterling, eds. Making Minds: The Shaping of Human Minds through Social Context. Philadelphia, PA: John Benjamin's Publishing Company. 2007; and Ian Craib. Experiencing Identity. London, UK: SAGE Publications. 1998. for basic introductions.
} 
so long as we are clear about what we are doing. As Clifford Geertz noted over thirty years ago, "it is not necessary to know everything in order to understand something...[we should be] guessing at meanings, assessing the guesses, and drawing explanatory

conclusions from the better guesses..."60 I want to take the first step on that dialectical path, encouraging others to follow me.

\section{The Production of Ideological Identity: Edgard Leuenroth}

Though I cannot go into detail for each here, in Figure 1.2 I have included a sample of the many factors that go into the formation of individual ideological identities. I must caution that there is no causal or linear relationship between each factor in the diagram, nor is the diagram meant to exhaust the confluence of categories that influence what we believe. Rather, the purpose of the schematic is to assist the reader in thinking about ideological identity construction in broad terms.

Thus, each factor both overlaps and intersects with all other factors in a nonnested manner to form an individual's ideological identity. The factors are not mutually exclusive, nor are some factors necessarily determined by others, though in forming argumentative statements out of these factors, causality and determination will be necessary. In all cases, the specific combination and degree to which each factor plays a role are contingent on the specific nature of the ideology, the aspect of the ideology that is being articulated, and the relational dynamics between each of these factors.

\footnotetext{
${ }^{60}$ Clifford Geertz. The Interpretation of Cultures. New York, NY: BasicBooks, 1973. p. 20
} 
Figure 1.2: "Factors Influencing Ideological Identity Formation"

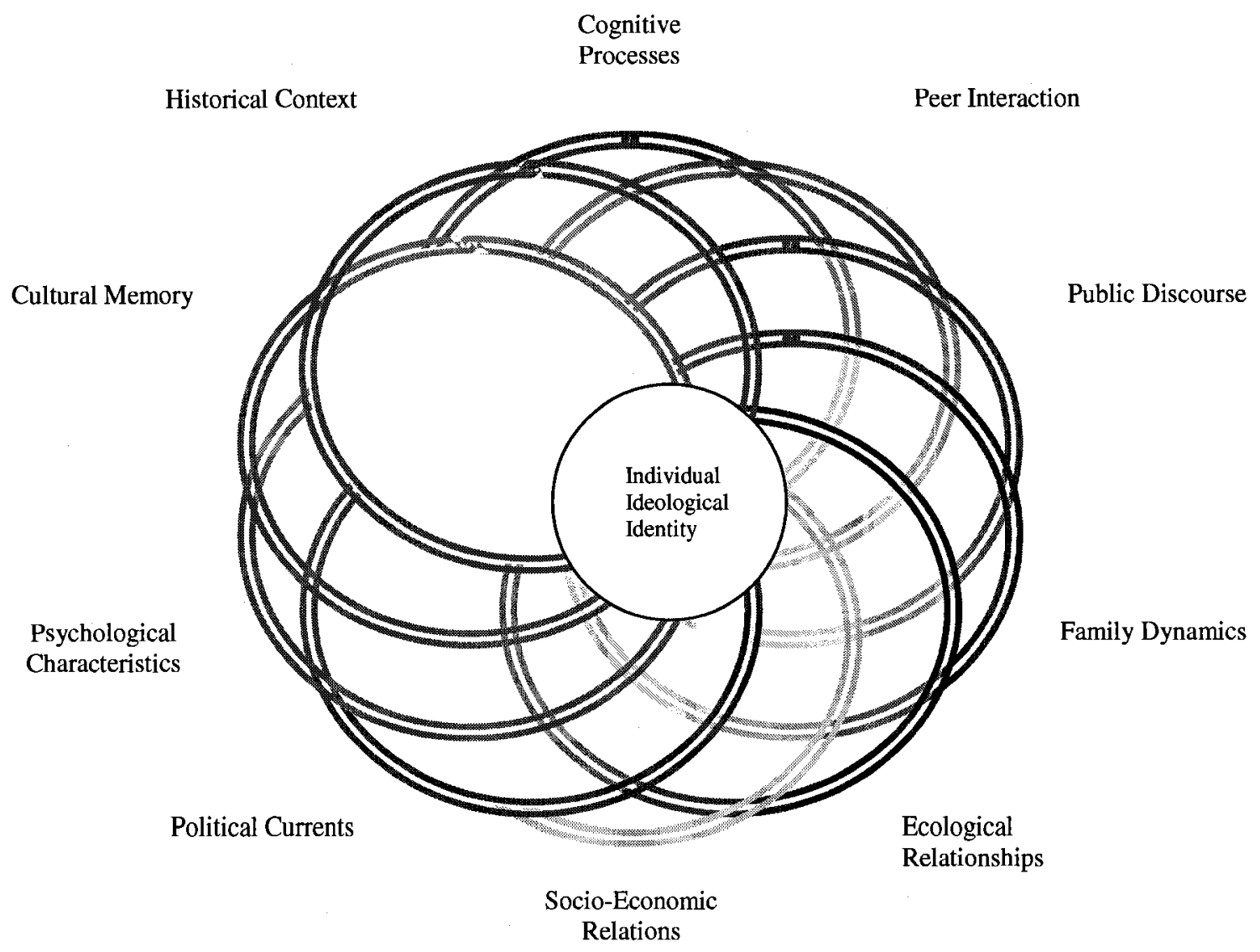

Let us now set up the 'big picture' of Leuenroth's ideological identity formation that will be spelled out in more detail in the following chapter. As mentioned in the introduction, because of lack of available sources, I leave out important factors such as family dynamics and cognitive processes. 
Leuenroth's brand of anarchism, incessantly political, must largely depend on the range of political beliefs and options available to him at the time. In the late nineteenth century, many of these beliefs were transmitted to Brazil from Europe, in the form of anarchist and libertarian tracts against imposed rule, slavery and serfdom produced by writers such as Proudhon and Bakunin, and in the form of experiences of recent immigrants arriving in the country, especially after 1889 . Yet, the cultural traditions contained in the history of the state of São Paulo would also provide a firm homegrown foundation for anarchist and libertarian ideologies. One must remember that Brazil in the late nineteenth century was a post-colonial empire still struggling with the construction of its national identity in relation to its European counterparts, and thus political currents explicitly rejecting dominant European political ideals as imposed by domestic elites, held some sway within marginalized discourse ${ }^{61}$. Undoubtedly, this political fervor found in Brazil at the end of the nineteenth century was facilitated by a relatively nascent though extremely vibrant - print culture. Thus, anarchist beliefs, if not fully articulated in the 1880s when Leuenroth was growing up, were hardly absent in the political culture or in public discourse, as I will demonstrate in the next chapter.

Socio-economic relations were in flux at the time of Leuenroth's birth in the state of São Paulo as well. The abolitionist movement was gaining strength, which would ultimately end the once-dominant labor institution that drove the state's economy. Dependent on a booming export crop, coffee, many of the state's municipalities, including Mogi Mirim where Leuenroth was born, and the state capital where he lived for most of his life, experienced massive growth and industrialization. This period of

\footnotetext{
${ }^{61}$ On this issue, see Jeffrey D. Needell. "The Domestic Civilizing Mission: The Cultural Role of the State in Brazil, 1808-1930". Luso-Brazilian Review. Vol. 36, No. 1. 1998. pp. 1-18
} 
economic transition would provide dissatisfaction with the status quo, and, I argue, would expand the range of 'thinkable' options for the ordering society that a young mind could perceive. In contrast with a child born two decades later in an urban center like São Paulo, where the relative homogenization of the wage relation would be all a youth would know first-hand, Leuenroth witnessed drastic changes to the socio-economy that, as part of his interpreted reality, would consciously and unconsciously affect the way he perceived the world ${ }^{62}$.

Ecological relationships have been given short shrift in biographies in the past, but I argue that they play an important role in forming our beliefs. The town of MogiMirim, where Leuenroth was born and spent his earliest years was booming when he left it, but despite its city status, offered a relatively rural experience to its residents. Chroniclers of the city have called it a "little urban space" (pouco espaço urbano), but it boasted a population density of only 18.8 people per square kilometer ${ }^{63}$. As one can see in a photo of Leuenroth's house circa the early 1880s in the following chapter (Figure. 2.1), there would have been ample open space to run around, unrestricted, unrestrained free. Whether or not this factor contributed to the development of Leuenroth's anarchist ideology in any concrete or significant way is impossible to tell. Yet it merits inclusion from a critical biographical standpoint because of the fact that it offered a young boy a different perspective from the one he would later have living in the crowded and

\footnotetext{
${ }^{62}$ This echoes the argument made by Douglas Kellner, who posited that it was the condition of exile and emigration that played a key role in the formation of the beliefs of critical theorists such as Horkheimer and Adorno. According to Kellner, "...those in exile from their homeland often find themselves in a land that is strange, and are sometimes able both to view conditions in their home country from a different perspective and to gain original perceptions of conditions in the country in which they find themselves exiled". It is not difficult to see a similar process at work if we substitute references to places with references to times. Douglas Kellner. Critical Theory, Marxism, and Modernity. Baltimore, MA: John Hopkins UP. 1989. p. 81 63 "História de Mogi-Mirim". City Brazil. 2007. http://www.citybrazil.com.br/sp/mogimirim/historia.htm
} 
unsanitary working-class São Paulo neighborhood of Brás, where Leuenroth moved to in 1884.

All of these factors would continue to play an important role in Leuenroth's growth when he moved to São Paulo and began his professional career. In doing so, he would also have had the opportunity to meet and interact with people expressing a diversity of views. Leuenroth highlighted some of those encounters in an interview conducted with him in 1968, the year that he died, and I expand on them more in the following chapter. The fact that Leuenroth was consistently surrounded by marginal - if not 'radical' - ideas certainly contributed to his budding beliefs in freedom and equality. Had he been subjected to only mainstream discourse, hammering in its ideas of the fixity of society and the necessity of status quo, it is unclear whether he would have had the tools with which to develop his beliefs to the maturity that he did. Moreover, this exposure would have a snowball effect once Leuenroth consciously grasped his ideological perspective, apparently at around age 19: Leuenroth would actively involve himself in communities of interest where people shared his perspective (or similar perspectives), though he would also engage those in the mainstream as well.

Although I do not discuss family dynamics in the biography in any sustained manner, they too were undoubtedly important. It seems that Leuenroth's brothers, at least in their early years, were actively involved in the anarchist press alongside him, and his younger brother João even participated as treasurer in the $2^{\text {nd }}$ Congress of the Confederação Operária Brasileira in $1912^{64}$. Including his wife and children, Leuenroth

\footnotetext{
${ }^{64}$ Dulles. Anarchists and Communists in Brazil, p. 27. It also seems that in 1913, Leuenroth's brother Eugênio, who would later become a bastion for the modern Brazilian advertising industry, was a parliamentary socialist. See Edgar Rodrigues. Os Libertários. Rio de Janeiro: Editores Associados. 1993. p. 199
} 
received positive reinforcement and support from his family members that would aid him in the articulation and practice of his ideological beliefs ${ }^{65}$.

It is clear that some psychological or cognitive factors contributed to Leuenroth's growth and success as a driving force in the anarchist community. In the next chapter, I briefly explore some of the social psychological factors that might explain why Leuenroth made the transition from an individual typographer with his own personal beliefs, to an active participant in collective organizations aimed at pushing an agenda bigger than that of each of their members. The desire to be a part of a collectivity with its own meanings and impacts on identity, I argue, played an important role through mutual reinforcement in encouraging Leuenroth's active participation in various social projects.

What in the end is the 'truth' of what made Leuenroth adopt the beliefs that he did, is a pipe dream that I will leave to objectivists to trouble over. I am, however, interested in prompting a vibrant debate on the various factors that might have contributed to Leuenroth's formation of his ideological beliefs. In doing so, we, as scholars, will gain a clearer picture of the underlying social, historical, political and cultural processes that made that moment in the state of São Paulo unique. Not only do we gain insight into the individual while conducting biographies, but also as the schema above demonstrates, of the 'negative space' that is an integral complement to the construction of that individual. The following chapter seeks to provide a partial biography of Edgard Leuenroth's

\footnotetext{
${ }^{65}$ Though interestingly enough, a quote by Paul Avrich paints a more turbulent picture, at least after Leuenroth's death: "The Leuenroth family, 'enthusiastic' with the gesture of payment in dollars that Dulles made [upon] arriving at the library of [Germinal's] father in order to get from it what he needed, 'forgot' that the same library was left by private will to a group of six people, who had to organize it as a public consultation archive, in whose group was included Edgar Rodrigues. [The family] decided 'to ignore' the will, and to sell the library, betraying the desires and the idea of its father". See Edgar Rodrigues. Trabalho e Conflito: Pesquisa Histórica, 1900-1935. Rio de Janeiro: Gráfica Editora Arte Moderna. 1977. p. 11
} 
formation and growth, covering the years 1881 to 1917 , implicitly and explicitly exploring some of the factors described above. 


\section{Chapter 2: Edgard Leuenroth: Formation and Growth, 1881-1917}

What it means to be an "anarchist" is as complex, fluid and shifting as the history of the term itself demonstrates. Anarchists have been brutally repressed, culturally denigrated, and socially marginalized, as in the case of Stalinist USSR ${ }^{66}$. But they have also been hailed as defenders of freedom, been part of large cultural movements, and put their ideals into practice outside of a statist framework, as in the Northeastern United States in the mid- $19^{\text {th }}$ century, and during the Spanish Civil War ${ }^{67}$. The Brazilian experience straddling the $19^{\text {th }}$ and $20^{\text {th }}$ centuries, echoing those of countless other locales where anarchism was struggling against the power of state and capital, vacillated between these two poles. Anarchism in Brazil grew in stature so that it eclipsed socialism as a political and social force in the early $20^{\text {th }}$ century ${ }^{68}$. Yet alongside this growth came stunning repression in the form of police brutality, mass layoffs, and the blacklisting of anarchist organizers from future employment in their trades ${ }^{69}$. Self-identification as an anarchist, then, was both a source of pride and solidarity, as well as a dangerous act of self-sabotage in Old Republican Brazil.

This chapter aims to outline the formative years of Edgard Leuenroth's life, and his intellectual and associational growth that led him to become such a commanding force in the anarchist wing of the Brazilian labor movement. Utilizing the critical biography methodology enunciated in the Introduction, and building on the factors contained in the schematic and described in the first chapter, this chapter will explore the underlying social context in which Leuenroth lived that ultimately helped him to shape

${ }^{66}$ George Woodock. Anarchism, p. 355-6.

${ }^{67}$ Ibid. p. 389,25

${ }^{68}$ John F.W Dulles. Anarchists and Communists in Brazil, p. 5

${ }^{69}$ Ibid. p. 17-8 
and articulate his ideological identity, justify his foundational values, and elucidate his experience of identifying as an anarchist. This chapter begins with the early years of his life, from 1881 - 1886 , putting forth a number of factors that might resonate with a young boy growing up in a small hinterland town, and as a child living in São Paulo. The second section charts his early adolescence, living and laboring in a working-class district in the city of São Paulo, by looking at some of the meaningful social relationships he formed along the way. The third section documents his rise up the ranks of notable anarchists in the labor movement until the General Strike of 1917, of which Leuenroth was dubbed the mastermind. Finally, the chapter concludes with a summary of the arguments, and calls for more scholarly work and debate regarding the life of Edgard Leuenroth.

The city of Mogi Mirim, in the state of São Paulo, was very sparsely populated when Edgard Leuenroth was growing up. With an area of nearly $640 \mathrm{~km}^{2}$ in 1886 , and a population of little over 12,000 people, it would have seemed almost rural to a young boy. Indeed, a large number (over $8 \%$ in 1874) of houses in the municipality were curiously uninhabited, further contributing to the sense of open space. Yet it also retained a "big city feel", a role it had been playing since an 1849 provincial ordinance granted it 'city' status. When Leuenroth was born, on October $31^{\text {st }}, 1881$, the city was home to four churches, and a city hall, and had two to three full-time police officers ${ }^{70}$. Indeed, it was something of a boomtown during the years that Leuenroth lived there. Between 1885 and 1886 , it ranked fifth in income in the state, though in subsequent years, it never even

\footnotetext{
70 "História de Mogi-Mirim". City Brazil. 2007. http://www.citybrazil.com.br/sp/mogimirim/historia.htm
} 
made it into the top $12^{71}$. By 1885 , it was home to a brand new theatre and a public library, attracting the attention of the editors of A Provincia de São Paulo who on Feb. $27^{\text {th }}, 1885$ remarked, "this is a city that is making real progress",. In short, Mogi Mirim was "a little urban space" in the heart of the coffee-dominated center of São Paulo state, integrating the social experience associated with urbanity with the specific ecological relationship that results from rural living ${ }^{73}$.

Fig. 2.1: "The house where Leuenroth was born and lived until moving to São Paulo city"74

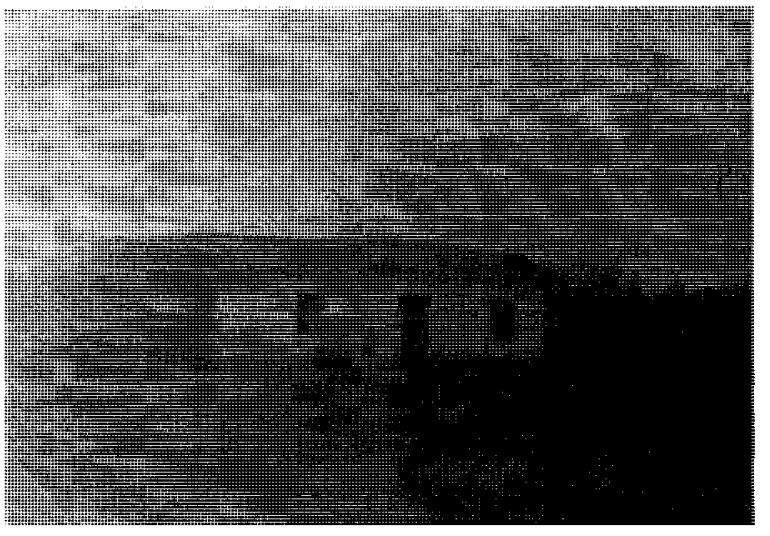

Like every city, Mogi Mirim has a distinct history that has influenced its character and culture. Since early colonial times, northern São Paulo state had been the primary staging ground for deeper expeditions into the Brazilian interior by bandeirantes seeking slaves, precious metals, and land. These groups, normally containing between two and three hundred men, many of whom were mamelucos ${ }^{75}$, were nominally under the orders of the Crown, but often their forays were as much about gaining freedom from colonial

\footnotetext{
${ }^{71}$ Joseph L. Love. Sao Paulo in the Brazilian Federation, p. 35

72 "Noticias". A Provincia de São Paulo. Feb 27th 1885. p. 2

73 "História de Mogi-Mirim". City Brazil. 2007. http://www.citybrazil.com.br/sp/mogimirim/historia.htm

${ }^{74}$ The house was owned by Leuenroth's maternal grandmother, who was the cousin of the Viscount of Rio Claro Courtesy of the Arquivo Edgard Leuenroth. http://www.ifch.unicamp.br/ael/websiteael_pesquisatematica/e-album/website-ael_ed-fami.htm

${ }^{75}$ This term denotes those of European and Indigenous parentage.
} 
bureaucracy as they were about strengthening and enriching $\mathrm{it}^{76}$. The markedly libertarian spirit of the bandeirantes formed the backbone of urban settlement in the Mogiana region of São Paulo state, and is evident in the flag of Mogi Mirim, which depicts two bandeirantes atop a motto that reads "I was born of the Bravery of the Natives of São Paulo"77. This aspect of the colonial culture of São Paulo undoubtedly influenced the kinds of values and ideas that would permeate the minds of residents as the bureaucratic structures of urban governance began to fall into place.

Indeed, Stuart Schwartz has pointed out that Brazilians have never viewed the State in a positive light, and that the meta-narratives of nationalism were never as accepted in Brazil as in Spanish South America ${ }^{78}$. This is reflected in much of the literary canon in nineteenth and early twentieth century Brazil, with its concern for nationalist independence from Portugal and nascent republicanism. Many works heralded the struggles of individuals fighting against the State, as in Euclides da Cunha's Os Sertões or, to a lesser extent, José Martiniano de Alencar's $O$ Guarany. These cultural manifestations of political sentiment were often in contradiction with one another, each valuing certain ideals above their counterparts ${ }^{79}$. Yet they formed a common ethical heritage of self-determination that would equally influence nationalist republicanism, libertarianism and anarchism.

\footnotetext{
${ }^{76}$ Bradford Burns. A History of Brazil, p. 64-5.

${ }^{77}$ Indeed, the São Paulo state motto reads "non ducor, duco", Latin for "I am not led, I lead" - emblematic of the libertarian spirit that permeates the region.

${ }^{78}$ Stuart Schwartz. "The Colonial Past: Conceptualizing Post-Dependentista Brazil". In Colonial Legacies: The Problem of Persistence in Latin American History. Ed. Jeremy Adelman. New York, NY: Routledge. 1999. p. 180-1.

${ }^{79}$ For example, Os Sertões is sympathetic to the determination of the poor residents of Canudos in maintaining their personal autonomy against the Brazilian state, while $O$ Guarany tells the story of elite resistance to the Portuguese Crown in $17^{\text {th }}$ century Brazil by a nobleman.
} 
Growing up in São Paulo, and especially in Mogi Mirim with its strong libertarian tradition, one could not escape the ideas that permeated local discourse, both public and private. As a product of a specific cultural heritage and historical epoch, Leuenroth's exposure to the currents shaping local and state culture in São Paulo would undoubtedly factor into the formation of his identity. Indeed, there is considerable evidence that cultural products played an important role in the formation of Leuenroth's beliefs - such as that his first serious journalistic endeavor was a newspaper of literary criticism, and that literature, both prose and verse, had a special place in Leuenroth's archival collection that he compiled throughout his life ${ }^{80}$. Clearly, his first encounters with Brazilian culture would have some impact in awakening him to the proletarian culture he would follow all of his adult life ${ }^{81}$.

Much more than elite literature, the local and state media would have a constant daily impact on people's lived experiences, shaping what they would discuss. That local media have the ability to fuel a sense of collective identity, and with it a particular brand of ideology, is well documented in academic literature - Benedict Anderson's Imagined Communities being one of the best expositions on the topic ${ }^{82}$. Brazil's peculiar colonial circumstances made that ability quite powerful. In 1808 , the Portuguese crown exiled itself to Rio de Janeiro because of the Napoleonic invasion, lifting the print ban that it had imposed on its colonial subjects in the process. In the ensuing criticism over the legality and honorability of this voluntary exile by these same colonial subjects in nascent periodicals and pamphlets, the King, Dom João VI, responded in like kind by offering

\footnotetext{
${ }^{80}$ Yara Aun Khoury. "Edgard Leuenroth: Uma vida e um arquivo libertários". Rev. Bras. de Hist. Vol. 17, No. 3. 1997.p. 116.

${ }^{81}$ Ibid. p. 117. I do not want to view culture in such narrow and static terms, though for simplicity's sake, I have left out the equally problematic distinctions of 'high' and 'low'.

${ }^{82}$ Benedict Anderson. Imagined Communities. New York, NY: Verso. 1991.
} 
alternative explanations for his exile that painted it in a positive light. This had the effect of legitimizing the contestation function of the local press in Rio de Janeiro, which consequently spread throughout the colony ${ }^{83}$. Roderick Barman has noted that this opening created the conditions for an "intensified and accelerated" political socialization among the literate elite against the colonial state, and later, the empire ${ }^{84}$. By the $1880 \mathrm{~s}$, the local press tradition in interior São Paulo was vibrant, facilitated by a well-developed rail network ${ }^{85}$ that allowed urban papers access to readers in rural towns on the day of publication, and a few papers wielded considerable influence in the hinterlands, with the largest by the mid-1880s being the heavily Republican A Provincia de São Paulo ${ }^{86}$.

The paper routinely praised idealists who generically supported their Republican cause. This meant the editors often found themselves aligned quite closely with anarchist thinkers of the time in that they wanted to throw off the shackles of empire. One interesting article favoring anarchist ideals, entitled "Jean-Jacques Rousseau: Judged by Pierre-Joseph Proudhon", appeared in A Provincia on Jan. $9^{\text {th }}, 1886$. The article garnered front-page attention and heaped mounds of praise on the self-described anarchist, stating

Proudhon, the most vigorous pamphleteer, one of the most coherent thinkers of our time, one of the most daring defenders of the democratic cause, is able to be exaggerated at times as unjust, or even cruel, but he is always sincere...Proudhon is one of those who, although much read, is always a pleasure to reread. He is a fighter, he is strong, he is a man ${ }^{87}$.

\footnotetext{
${ }^{83}$ Kirsten Schultz, Tropical Versailles: Empire, Monarchy, and the Portuguese Royal Court in Rio de Jeneiro, 1808-1821. New York, NY: Routledge. 2001. pp. 117-9

${ }^{84}$ Roderick Barman. Brazil: The Forging of a Nation, 1798-1852. Stanford, CA: Stanford UP. 1988. p. 44

${ }^{85}$ Mogi-Mirim was one such town to have access to major urban dailies. In 1875, the Comphania Mogiana inaugurated its Linha Tronco, which ran from Campinas to Mogi-Mirim. Extensions were added in 1878, and throughout the 1880s. See: Benicio Viero Schmidt, "Modernization and Urban Planning in $19^{\text {th }}$ Century Brazil”. Current Anthropology, Vol. 23:3. (Jun, 1982). p. 256

${ }^{86}$ Joseph L. Love. São Paulo in the Brazilian Federation, p. 91. Love also demonstrates the power of $A$ Provincia in shaping public opinion when he argues that the driving force behind Brazilian Republicanism was not the Republican Manifesto or the emergence of the Third Republic in France, but A Provincia itself. Ibid, p. 103.

87 "João Jacques Rousseau: Julgado Por Pedro José Proudhon". A Provincia de São Paulo. Jan. 9th, 1886.
} 
This patriarchal reference demonstrates just how highly the editors thought of Proudhon. The fact that this article was published only three years before the coup that would overthrow the empire and make Brazil a republic makes it very easy to see the attraction in praising Proudhon over Rousseau. Moreover, the editors, F. Rangel Pestrana and Américo de Campos, deliberately aligned themselves with the Partido Republicano Paulista, toeing all the party lines in their editorials except for the proclamation of the Republic $^{88}$. Before publishing a segment from Of Justice in the Revolution and the

Church that criticizes Rousseau for its readers, the editors point out that

[Proudhon's] critical assessments on Rousseau, Lamartine, Mme. Roland, Stael, Necker de Saussure, and George Sand are tremendous, but how many of us are there that have made them without the courage to confess them publicly? Proudhon has over all of them [and us] this quality - he is not a coward $^{89}$.

However, libertarian and anarchist ideas were not only disseminated through the media. They also formed part of the intellectual upbringing of many São Paulo elites, especially those who had traveled to Europe. One can see the effects of anarchists and anarchist ideals in the striking case of two brothers Antônio Prado (1840-1929) and Martinho Prado Jr. (1843-1906). Hardly an anarchist, Antônio was the leader of the provincial Conservative party in São Paulo for much of the latter half of the $19^{\text {th }}$ century, including during an election held on the date of Leuenroth's birth ${ }^{90}$. While a youth traveling in France in the early 1860s, Antônio happened to read a pamphlet on Italian politics by Proudhon that derided Brazil's Emperor Dom Pedro II. At first indignant that this French anarchist would dare attack his nation, he came to the realization that what Proudhon had said was "the pure truth" and subsequently viewed Brazilian politics as the

\footnotetext{
${ }^{88}$ Joseph Love. São Paulo in the Brazilian Federation, p. 105.

${ }^{89}$ Ibid.

${ }^{90}$ Levi, p. 90; "Boletim Eleitoral”, A Provincia de São Paulo. Nov. 1st 1881.
} 
"most abject and ridiculous thing that can be imagined" $"$. Of course, this youthful indifference was quickly discarded upon his return to Brazil for political priming that would lead him to continue the ideological work of his older relatives.

Martinico, however, took quite a different path. Though he did not visit Europe until well into his 40s, Martinico eagerly absorbed the works of nineteenth century European economists and even wrote under the pen name "Rossel" in homage to a victim of the Paris Commune ${ }^{92}$. He broke with family tradition by winning a seat for Republicans in the provincial assembly in 1878 and became the only party member to continuously hold his office until $1889^{93}$. Martinico praised the libertarian and democratic movements in Europe, arguing that they should be adapted to the Brazilian context, condemned the emperor for his "spinelessness", and often spoke about the struggle between capital and labor gripping Europe at the time. He was also an extremely effective advocate of immigrant labor and the chief Republican representative on the issue, founding the Immigration Promotion Society that would eventually inadvertently bring in a number of anarchist thinkers from Portugal, Italy and Spain ${ }^{94}$.

These short vignettes of two major São Paulo political personalities serve a dual role: on the one hand, they demonstrate that libertarian, if not anarchist, ideas were circulating across the state via periodicals and in political speeches delivered by candidates sympathetic to them. However, on the other, they also serve to lay out the intersection of political values with the local social economy in the Mogiana region, since the Prado family was one of the principal fazendeiros in interior São Paulo. It is difficult to say

\footnotetext{
${ }^{91}$ Qtd. in Levi, The Prados of São Paulo. p. 57

${ }^{92}$ Ibid. p. 61

${ }^{93}$ Ibid. p. 90

${ }^{94}$ Ibid. p. 61-2; Joseph Love, São Paulo in the Brazilian Federation, p. 105
} 
what kind of direct contact the Leuenroth family would have had with these two Prado elites, but their perspectives would appear almost daily in newspapers such as $A$ Provincia. Let us return to Mogi-Mirim.

By the time Leuenroth was born in 1881, much had changed in the city, and yet much had remained strikingly the same. Politically, Mogi Mirim had grown from its humble beginnings as a settlement outpost that João Mendes Júnior estimates emerged between 1719 and 1721 , to an urban area that had obtained legal city status in 1849 . The predominantly agricultural economy had been transformed away from staple food production, mainly for relatively local trade with bandeirantes passing through, to sugar in the $18^{\text {th }}$ and early $19^{\text {th }}$ centuries, then to massive coffee fazendas oriented towards the coastal export market that dominated the Brazilian economy into the twentieth century. One such plantation, Camp Alto, administered by Martinho Prado, the father of both Antônio and Martinico, provides some insight into the life in and around Mogi Mirim when Leuenroth was very young.

Acquired in 1839 with the dowry money obtained from Martinho's wife, Veridiana, the 22,800-acre sugar fazenda Camp Alto was reconfigured for coffee production in the early $1850 \mathrm{~s}^{95}$. This plantation, along with Engenho do Arari, a much smaller one located within the municipal bounds of Mogi-Mirim itself, likely furnished local families with economic opportunities under the colonato system and, to a lesser extent, through sharecropping.

The colonato system coupled guaranteed income for laborers tending the coffee trees throughout the production cycle with piece-rate income derived from the particulars of

\footnotetext{
${ }^{95}$ Levi, The Prados of São Paulo, p. 68-73
} 
each specific harvest ${ }^{96}$. This combination of contract wages and 'commission' ensured a certain amount of autonomy for workers alongside the coercion implicit in the wage relation. Living in the smaller city of Mogi Mirim, one would have been able to witness quite clearly the struggles for freedom and autonomy by colonos, only partially tethered to the contract, which might not have been as readily evident in major urban centers with a more homogenized wage relation. For a young mind, learning to understand the social system that it was a part of, alternative options to capitalist oppression might leave a considerable impression.

Alongside these free laborers toiled a slave labor force until abolition in 1888, though the use of the system of slavery for coffee production began its decline by the early $1860 \mathrm{~s}$ in the state of São Paulo ${ }^{97}$. Indeed, into the twentieth century, nearly $80 \%$ of the agricultural labor force in the state was engaged in work under the colonato system, making it by far the dominant labor institution during Leuenroth's childhood ${ }^{98}$.

Moreover, alongside the large-scale semi-feudal relations of the monoculture coffee industry, the economy of interior São Paulo in the late $19^{\text {th }}$ century was comprised of many independent or semi-independent entrepreneurs peddling wares and offering services in the small towns and villages. Such was the occupation of Edgard Leuenroth's father, Waldemar Eugenio, who ran 'The Red Lion' pharmacy specializing in both allopathic and homeopathic medicine in nearby Mogy-Guassú ${ }^{99}$ (Figure 2.2). Many

\footnotetext{
${ }^{96}$ Thomas H. Holloway. Immigrants on the Land, p. 74-77.

${ }^{97}$ Ibid. p. 73

${ }^{98}$ Verena Stolcke. Coffee Planters, Workers, and Wives, p. 23

${ }^{99}$ There are discrepancies in the academic literature regarding the specific occupation of Edgard Leuenroth's father, as between Dulles' Anarchists and Communists who places his profession as a pharmacist (p. 15), and Edgar Rodrigues' Os Companheiros, that seems to label Waldemar a medical doctor (p. 62). The Arquivo Edgard Leuenroth has released a detailed prescription pad of Waldemar's that appears to lay this question to rest.
} 
others posted advertisements in A Provencia, selling everything from food to livestock equipment, symbols of an emergent capitalism.

The entrepreneurial alternative to wage labor would also have resonated with Leuenroth, especially since it would have been part of his familial upbringing. The ability to be free from the colonato, from slavery, from wages - even if one was still beholden to a rentier-class - by establishing a small business was something that many in Brazil aspired to, be they former slave, immigrant, or disadvantaged mulatto. By combining an element of freedom with self-determination, independent businesses would have added another tinge of libertarianism to the realm of possibilities a child discerning their world could discover and relate to their own lives. That entrepreneurialism was firmly embedded in capitalism, thus producing as many failures as successes (with intense hardships for both along the way), might have contributed to why Leuenroth ultimately rejected it.

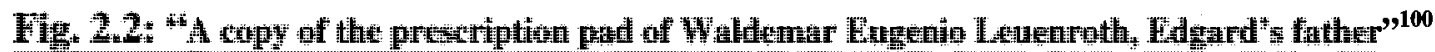

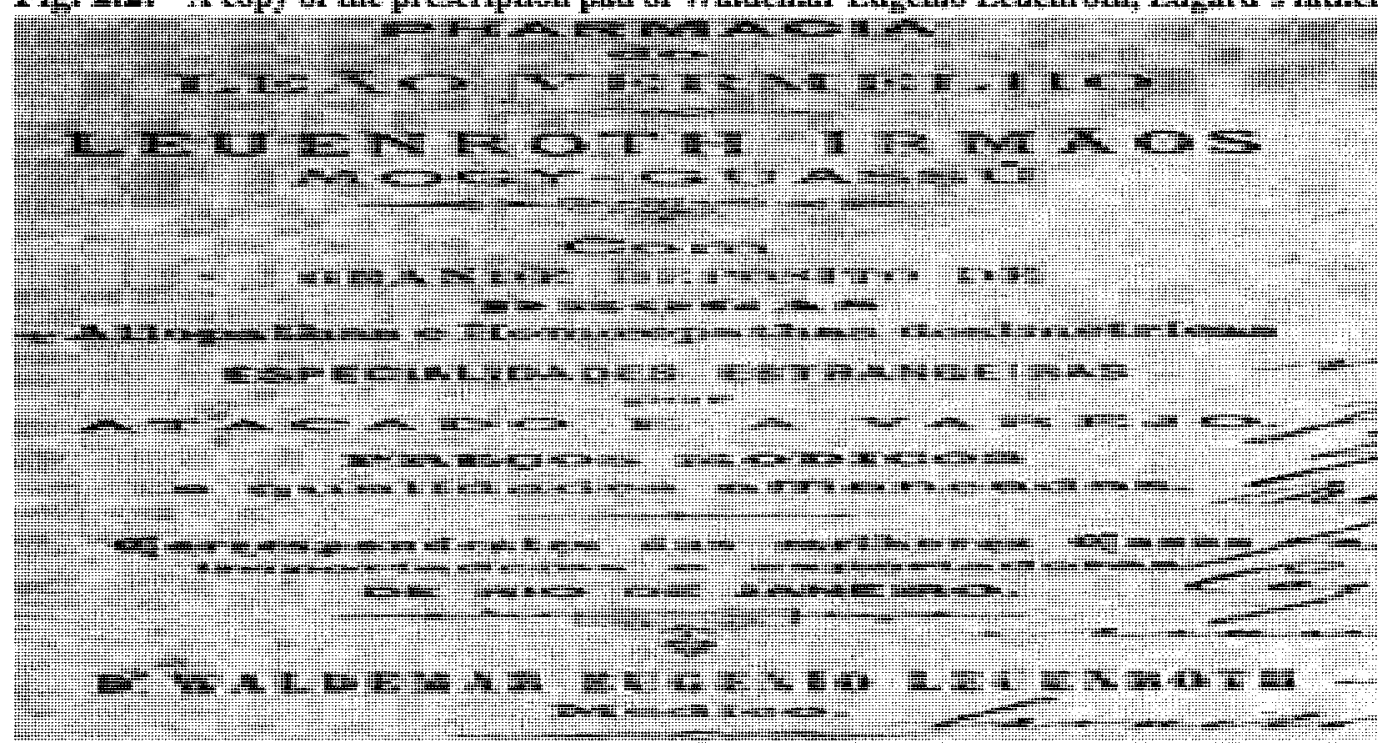

${ }^{100}$ Courtesy of the Arquivo Edgard Leuenroth. http://www.ifch.unicamp.br/ael/websiteael_pesquisatematica/e-album/website-ael_ed-fami-valde.htm 
II

Tragedy struck the Leuenroth family when Waldemar died when Edgard was only three. With no income source, Edgard, his mother Amélia, and his three brothers, Waldemar, Eugênio, and João, quickly moved to São Paulo city ${ }^{101}$. This event necessarily changed his life trajectory, transforming a relatively quiet and sedentary semi-rural existence to one that would force him to confront the urban social struggles of turn of the century São Paulo head on. The most likely place to do this for a young boy, outside of the day-to-day contact that Leuenroth was to have living in Brás, an almost wholly working class district in the city populated largely by Italian immigrants, was in school. Yet, Leuenroth stated that he never had regular studies, despite the fact that he was a five year-old boy living in the big city at a time when state involvement in education was ramping up all across Latin America ${ }^{102}$. Most of his education he claimed he learned on his own, referring to himself as 'self-taught', implying that his knowledge could not be attributed to formal classroom education.

Indeed, a school was not the only place where a child could get a good education in the last decade of the $19^{\text {th }}$ century, especially on the kinds of topics that Leuenroth was to engage throughout his life. Leuenroth later said in an interview published in 1968, shortly before his death, that he "gathered everything in the immense university of life"

Wherever he found himself, he would be sure to absorb the social dynamics, the relations

\footnotetext{
${ }^{101}$ Yara Aun Khoury, "Edgard Leuenroth: Uma vida e um arquivo libertários". Revista Brasileira de História. Vol. 17:33. 1997. p. 117

${ }^{102}$ See both Mark D. Schuzman, "Childhood Education and Politics in Nineteenth Century Argentina: The Case of Buenos Aires". The Hispanic American Historical Review. Vol. 70: 1. 1990. pp. 109-138; and Irene Rizzini, "The Child-Saving Movement in Brazil". In Minor Omissions: Children in Latin American History and Society. Ed. Tobias Hecht. Madison, WI: University of Wisconsin Press. 2002. pp. 165-178 for two diferent but complementary readings of state childhood intervention in the region.

${ }^{103}$ Traços biográficos de um homem extraordinário. Dealbar. São Paulo. 17 dez. 1968. Ano.2: 17. p. 1
} 
of production, and the overall political economic structure. This holistic educational practice captures Leuenroth's attitude and philosophy towards social change as well. Edgar Rodrigues, the Portuguese and Brazilian anarchist chronicler has claimed, "There was nowhere he would not go, nor did he ever miss a chance to spread his ideas" ${ }^{\text {"104 }}$. The entire social landscape provided fertile terrain to draw ideas from, and thus it was necessarily the place to advocate progressive concepts in order to influence the relational dynamics across all social strata.

Yet, in 1890, Leuenroth did obtain a formal classroom education, if only for a short time. He was enrolled in the Escola Modelo do Carmo, named after the street on which it was located, in its very first year. Opened for Sept. $1^{\text {st }}, 1890$, the school's assistant director was an English woman named Miss Marcila Browne ${ }^{105}$. Leuenroth later remembered her as favorably as one might, calling her "willowy and strict". He did recognize her contribution, noting that despite his brief relationship with her, she left him with great memories ${ }^{106}$.

However, Leuenroth left school "out of principle", rather than out of necessity, after completing only a year ${ }^{107}$. At the age of 10 , he entered the world of work, first as an office boy doing basic clerical functions such as cleaning and delivering messages for the title broker Leonidas Moreira on Commercial St. (today Álvares Penteado) ${ }^{108}$. Leuenroth described this experience as formative in his political socialization:

There I heard, for the first time, debates about socialism, the consequence of the presence of a man who participated in the initial movements of this ideology in our milieu. Estevão Estrêla was his name.

\footnotetext{
${ }^{104}$ Edgard Rodrigues, "Edgard Leuenroth, 1881-1968". In Against All Tyranny! Essays on Anarchism in Brazil. Trans. \& ed. by Paul Sharkey. Berkeley, CA: Kate Sharpley Library. 2003. p. 20

105 "Escola Modelo do Carmo". Centro do Referência em Educação Mario Covas. Governo do Estado de São Paulo. http://www.crmariocovas.sp.gov.br/pdf/neh/1825-1896/1890_Escola_Modelo_do_Carmo.pdf ${ }^{106}$ Dealbar, p. 1

${ }^{107}$ Ibid.

${ }^{108}$ Ibid. pg. 1/4
} 
He was a corpulent Bahian, clearly showing himself to be intelligent and well educated, he spoke with Northeastern ease (agility). Immediately on his arrival, he used to transform the office into the center of an animated tertulia ${ }^{109}$

That the workplace introduced Leuenroth to his first conscious memories of socialism is hardly a surprising idea, especially if we consider the context in which Leuenroth left school to begin work. In 1888 , Brazil abolished slavery, becoming the last country in the Western hemisphere to do so. Though there had been a gradual elimination of the system of slavery through the "Free Womb Law", passed in 1871, the institution did not officially end until the Golden Law of May $1888^{110}$. Abolition was something that was discussed in not only urban workplaces, but all across the empire. Leuenroth praised what he called the "heroes of abolition" in his 1963 book, and referring to slavery in general he wrote:

It is always true the proverb that says 'He who is poor is a slave', but the other proverb doesn't stop being equally true which affirms, 'he who is enslaved is, or becomes, poor because he loses all the best characteristics of the human personality ${ }^{111}$

That Leuenroth was in the formative stages of his moral development as the last formal bastion of nationally sanctioned slavery in the Americas ended is highly significant. It allowed him, and many others, to see that choices between various options go into establishing a social system. If an institution with as much depth in Brazilian society, with such a lengthy history propped up by nationalist mythologies and cultural tropes could be altered, then surely other aspects of society could as well. However, much more directly, abolition provided discursive space in which to debate the nature of the human

\footnotetext{
${ }^{109}$ Ibid. pg. 4; The terúlia is a term used to denote a social gathering in Iberia and Latin America where participants meet to discuss literary and political issues. The way Leuenroth refers to them, they are surely informal.

${ }^{110}$ Of course, slavery continued unofficially, if in reduced capacity, after this date. Tom Phillips points out that there are anywhere between 25,000 and 250,000 modern day slaves in Brazil right now. See Tom Phillips. "Raids across Brazil Free 4,000 Slaves". The Guardian. Jan 16 2006 . p. 22 http://www.guardian.co.uk/world/2006/jan/16/brazil.mainsection

${ }^{111}$ Edgard Leuenroth. Anarquismo: Roteiro da Libertação Social. Rio de Janeiro: Editôra Munda Livre. 1963. p. 230,44
} 
condition, evidenced in the tertulias catalyzed by Estrêla. Any discussion of the 'politics of the day' would necessarily involve an engagement with fundamentally social issues, and this exposure to deeply political questions would certainly require a young boy to grapple with them.

Only a year later, in 1889 , elite Brazilians threw off empire for republic in a bloodless coup initiated by General Manuel Deodoro da Fonseca. Here, another major institutional change would have immense ramifications on all aspects of Brazilian life. In retrospect, Leuenroth viewed this event as a watershed moment for anarchists, though he was only a young boy at the time. Discussing the concretization of anarchist activity in Brazil, Leuenroth wrote, "The social libertarian movement began its activities in Brazil, in more or less materialized form, soon after the implementation of the republican regime" ${ }^{112}$. Robert J. Alexander has supported this claim, noting that the modern proletariat did not really emerge in Brazil until after the declaration of the Republic, since prior to this the country was predominantly agricultural and rural. This urban proletariat, Leuenroth included, became the focal point for the organized labor movement in which anarchists played a predominant role ${ }^{113}$. Thus, it was in tempestuous times that Leuenroth began his workplace socialization and continued his more general self-discovery. However, he would not stay in a single workplace for long. Soon after taking his first job, he became a sales assistant at a coffee plantation store, allowing him to see first-hand conditions for laborers, most of them recent immigrants.

Coffee was by far the most important commodity crop in São Paulo until the 1920s. Holloway demonstrates that state tax revenue on coffee exports as a percentage of

\footnotetext{
${ }^{112}$ Ibid. p. 105

${ }^{113}$ Robert J. Alexander. A History of Organized Labor in Brazil. Westport, CT: Praeger. 2003. p. 5
} 
total tax revenue ranged from $73 \%$ in 1892 to $61 \%$ in 1912, hitting a high of $78 \%$ in 1901. Immigration program expenditures for the state, designed to supply labor to the burgeoning coffee industry, also skyrocketed, comprising $15.7 \%$ of total tax revenue in $1895^{114}$. Between 1891 and 1900, São Paulo received over 700,000 immigrants, $62 \%$ of Brazil's total immigration, with the vast majority coming from Italy, Portugal, Spain and Germany, and many bringing radical ideologies like anarchism with them ${ }^{115}$. These immigrants were often forced to purchase household and sharecropping supplies from the plantation stores where high prices, interest, and unfair accounting could impose near serfdom on them ${ }^{116}$. Leuenroth's exposure to this kind of exploitation would have solidified the sense of injustice of the Brazilian political economy that he would carry with him all of his life. In the next chapter, I will discuss the contributions of immigrants to the anarchist movement, arguing that the coffee boom and its corollary effects of inducing immigration were integral factors in the growth and militancy of the anarchist movement in Brazil.

Leuenroth again left the store in which he worked in 1895 at the age of 13 , this time finding something of a career in his next job. He was hired by the Companhia Industrial de São Paulo, a manufacturing firm involved in textiles, graphics, and match making ${ }^{117}$. Here, Leuenroth learned typesetting and publishing skills while working for their publishing arm, the Typographia da Companhia Industrial de São Paulo, that he

\footnotetext{
${ }^{114}$ Holloway. Immigrants on the Land, p. 46

115 Joseph Love, São Paulo in the Brazilian Federation, p. 10

${ }^{116}$ Walter Nugent. Crossings: The Great Transatlantic Migrations, 1870-1914. Bloomington, IN: Indiana UP. 1992. p. 130

${ }_{117}$ This company was also the first in Brazil to tap the bond market for capital. Ann Hanley. Native Capital: Financial Institutions and Economic Development in São Paulo, Brazil, 1850-1920. Stanford, CA: Stanford UP. 2005. p. 98
} 
would employ for the rest of his life. However, he did not look on his time there with any fondness.

The memories of my passage through those offices remain in my memory as an incurable wound. In [the company] I was a victim of an injustice that I have never been able to forget. [Working for the company] had the effect of an enormous moral impact, [which was reflected] in the formation of my libertarian conscience ${ }^{118}$.

One could find the sanctity of late nineteenth century Brazilian capitalism in a major firm such as the Companhia Industrial, and working conditions were hardly pleasant for typographers ${ }^{119}$. Indeed, according to Robert Alexander, the first strike in Brazil was a typographer's stoppage in Rio de Janeiro in 1857, indicating both the severity of their working conditions and their level of organizational capacity ${ }^{120}$. Michael Hall and Marco Aurélio Garcia have commented that the use of arbitrary force was quite commonplace in most factories, whether in typography or not, because of the "recentness of industrialization, combined with the newness and predominantly foreign origins of the working class". For someone like Leuenroth, born and raised in Brazil, "customary Brazilian mechanisms of social domination", including status assaults against ethnicity or age, or appeals to nationalism, were often enough to block complaints against unsafe, unsanitary, and grueling labor conditions ${ }^{121}$.

Leuenroth refused to expand on the injustices he faced at the Companhia Industrial in a later interview, stating that he had already recounted it in a book entitled

\footnotetext{
${ }^{118}$ Dealbar, pg. $1 / 4$

${ }^{119}$ For more detailed information on factory labor conditions, see Maria Célia Paoli "Working Class São Paulo and its Representations, 1900-1940". Latin American Perspectives. Vol. 14:2 Urban Latin America. Spring 1987. pp. 204-225. For conditions in Rio de Janeiro, see Teresa A. Meade 'Civilizing' Rio: Reform and Resistance in a Brazilian City, 1889-1930. University Park, PA: Pennsylvania State UP. 1997. pp. 121150 .

${ }^{120}$ Robert Alexander. A History of Organized Labor in Brazil, p. 6-7

${ }^{121}$ Michael M. Hall and Marco Aurélio Garcia. "Urban Labor". In Modern Brazil: Elites and Masses in Historical Perspective. Eds. Michael L. Conniff and Frank D. McCann. Lincoln, NE: University of Nebraska Press. 1989. pp. 164-5.
} 
"Dust of the Barricades", though he died before the book was ever finished ${ }^{122}$. In 1897 , Leuenroth left those dark years behind and began working for the newspaper $O$ Comércio de São Paulo, where he would hold a typographic position for twelve years. Looking back, he recognized this time as formative in his professional career stating, "With a brush in my hand, I began my contact with journalistic life" ${ }^{\prime 23}$. Besides this large and lengthy impact on Leuenroth's personal and professional development, his time at $O$ Comércio presents an interesting case for analyzing social interconnections in Republican era Brazil.

Leuenroth called $O$ Comércio "a true treasure trove of intellects". He worked alongside important notables in Brazilian journalism and politics such as Eduardo Prado, the director and Afonso Arinos, the editor-in-chief, though he emphasized the abilities of many others as well ${ }^{124}$. Eduardo Prado, the youngest brother of Martinico and Antônio, utilized $O$ Comércio as a pulpit by which to advance his brand of 'Catholic Liberalism',125, and campaign against the tyranny of the new Republic, which he viewed as "reactionary" when compared against the supposedly oppressive empire that had preceded $\mathrm{it}^{126}$. Between 1895 and 1897 , he published some fifty articles with titles such as "Violence of the Government" and "Governmental Anarchy", and he purchased the paper in 1896 with the backing of his mother, Veridiana ${ }^{127}$.

\footnotetext{
${ }^{122}$ Dealbar, pg. 1/4; See also: Francisco Foot Hardman "Poeira das Barricadas: Notas Sobre a Comunidade Anárquica”. In O Desejo, ed. Adauto Novaes. São Paulo: Companhia Das Letras. 1990. pp. 261-67.

${ }^{123}$ Dealbar, p. 4

124 Ibid.

${ }^{125}$ For more on this reading of Eduardo Prado, see Mark Hillary Hansen. Eduardo Prado, Liberal Monarchist and Catholic Nationalist: A Whig Rebel in Brazil's Old Republic. PhD Dissertation: Columbia University. 2002.

${ }^{126}$ Levi. The Prados of São Paulo, p. 127

${ }^{127}$ Ibid. p. 171
} 
As Leuenroth arrived at the newspaper in 1897, O Comércio was in the throes of a war, both in the press and to some extent in a physical sense. In Canudos in the Northeast of Brazil, the Republican state was desperately trying to put down what it viewed as a monarchical rebellion, which it connected to Eduardo Prado and $O$ Comércio, while in São Paulo it was trying to maintain its grip on the political discourse ${ }^{128}$. Prado and $O$ Comércio threw considerable support behind the Canudos rebellion by publishing articles stating that captives of the military campaigns were being forced into slavery and prostitution $^{129}$. This greatly angered the governor of São Paulo, Manuel Ferraz de Campos Sales who ordered the state police to break up peaceful 'monarchist' meetings in private buildings such as $O$ Comércio, fearing that they "would frustrate [his] attempts to get a foreign loan"130 . It also angered some of the residents of São Paulo who, after reading of an alleged financial and military link between $O$ Comércio and the Canudos rebellion in the Republican press, proceeded to sack and loot the newspaper's office ${ }^{131}$. Shortly thereafter, Eduardo Prado was forced into exile, leaving the parting shot "The republican regime claims to be founded on reason and not on faith, much less in force. In that case, why does it fear discussion?" ${ }^{\prime 132}$ O Comércio was closed due to press

\footnotetext{
${ }^{128}$ Canudos was a law-abiding settlement colony in the northeastern state of Bahia, led by a preacher named Antônio Conselheiro that attracted between thirty to thirty-five thousand people, which made it the second largest urban center in the state. Though it has been painted as messianic, millenarian, and monarchical by both its contemporaries and subsequently by scholars and novelists, Levine has argued that it was simply an autonomous movement that in the eyes of the State was antithetical to national interests. Robert Levine. "Canudos in the National Context". The Americas. Vol. 48, No. 2. 1991. pp. 207-8. See also, Robert Levine. Vale of Tears: Revisiting the Canudos Massacre in Northeastern Brazil, 1893-1897. Berkeley, CA: University of California Press. 1992.

${ }^{129}$ Qtd. in Rebecca J. Scott et al. The Abolition of Slavery and the Aftermath of Emancipation in Brazil. Durham, NC: Duke UP. 1988. p. 162

${ }^{130}$ Qtd. in Levi. The Prados of São Paulo, p. 172

${ }^{131}$ Ibid. p. 173

${ }^{132}$ Thomas E. Skidmore. "Eduardo Prado: A Conservative Nationalist Critic of the Early Brazilian Republic, 1889-1901". Luso-Brazilian Review. Vol. 12:2. 1975. p. 152
} 
censorship until 1898, when Prado returned as director, if less vigorously committed, until his death in 1901.

What does this brief narrative tell us about Edgard Leuenroth? First, that he maintained his exposure to ideals outside of the dominant political discourse. Though he was not able to participate in the article-writing process, he would be exposed to countless discussions and arguments on a wide range of topics that were mostly ignored in the Republican press. If the discussions and publications that came from the offices of o Comércio were not anti-statist, they were certainly anti-government. Eduardo Prado fought for civil rights and freedom of the press against a regime he rightfully viewed as more restrictive than the centralized imperial government and called attention to the poverty of those living in the hinterlands. He also "expressed genuine concern with what Brazilians called the 'social question' and with capitalism's abuse of workers...”, all themes that showed through in the newspaper's publications ${ }^{133}$. Leuenroth's encounters with these ideas would be integral in getting him to think critically about dominant societal institutions that defended the status quo and the privileges of dominant groups with vigor. Leuenroth recognized that his early years with the newspaper played a central role in shaping his understanding of the Brazilian political economy, noting that

I had there [in $O$ Comércio], of a certain fashion, the prolongation of my school courses...I put myself by the editing door, observing and listening, doing the same next to the proofreaders, and probing the tertulias of the improvised living room ${ }^{134}$.

We also see the impact that working alongside major literary figures had on Leuenroth after working there for less than a year, he began publishing a fortnightly journal of

\footnotetext{
${ }^{133}$ Levi, The Prados of São Paulo, p. 166; Indeed, it spoke on behalf of the poor so often that it is included in the Latin American Labor and Anarchist Periodicals microfilm catalogue. One article in 1906 even published a letter that Peter Kropotkin had written to the editors of A Terre Livre, an anarchist paper founded by none other than Leuenroth. "A Revolução Russa: Um autographo - Pedro Kropotkine". $O$ Comércio de São Paulo. 6 May 1906. p. 4

${ }^{134}$ Dealbar, p. 4
} 
literary criticism called $O$ Boi (The Ox). Leuenroth worked on $O$ Boi for about a year

with his brothers, who were also involved in the printing $\operatorname{trades}^{135}$. Leuenroth reminisced

about the conditions in which his paper was published:

Its office used to operate in a shed, situated in the depths of the slums (de um cortiço) on Maria Domatília street, at the time at the beginning of Brás [a neighborhood in São Paulo]. It used to be composed in a 'job case' [the storage case for the moveable type] made of matchboxes, with type, to a large extent, picked out of a typographer's garbage; It was printed in a hand press that was able to be transported under the arm, and used to have as director a northern lawyer Mr. Júlio Ramos, a resident of the neighborhood. The name of 'O Boi' was given to the little newspaper in order to take advantage of a cliché I found in the "pastel" I acquired with the printing press, for fifty cruzeiros, from a vender on Rua da Carmo ${ }^{136}$.

Leuenroth's direct involvement in the world of printing sparked a passion in him that he would not be able to quench. The act of writing up articles, gathering publishable material, placing the type and cranking out copy after copy of your work is exciting for many - witness the expansion of the contemporary corollary in the web log! At the time, in the late 1890 s, the prospect of reaching a reasonably large local audience would be attractive to anyone interested in engaging in public discourse. Leuenroth felt this desire: in an issue of the newspaper that paid homage to Victor Hugo, the opening line read, "the press is the voice of the people"137. He also felt that he was having some success in reaching the public, for in 1898 , he "metamorphosed" O Boi into the Folha Do Braz with the help of his brothers ${ }^{138}$.

Unlike most anarchist publishers of the time, Leuenroth and his brothers directly solicited advertisements in order to obtain funds for their paper. They wanted a

\footnotetext{
${ }^{135}$ See Khoury "Edgard Leuenroth: Uma vida e um arquivo libertários" p. 119. There is a great deal of confusion in the literature over just whom Leuenroth was publishing his early periodicals with. The newspaper itself prints the name "Cruz", but according to Liane Maria Bertucci, Leuenroth operated it with one Brazilio dos Santos Altro. See Liane Maria Bertucci, "Cidade, Saude e Militância Operária. São Paulo, Início do Século XX”. Conference Proceeding, 49 Congreso Internacional del Americanistas (ICA). Quito, Equador. 7-11 Jul, 1997. Fn. 5

136 Dealbar, p. 4

${ }^{137}$ Cruz \& Leuenroth. O Boi. September 12th, 1897. Anno 1, Num 5.

${ }^{138}$ Dealbar, p. 4.
} 
newspaper that would "develop the social function of condemning vices, spreading good principles of education in the terrain of hygiene, literature, arts, sciences and fraternity"139. In order to do so, they got involved in what Khoury calls a "true capitalist press" - providing advertising services, organizing classified ads and other commercial activities. In order to acquire funds for Folha, the four brothers created the advertising agency $A$ Eclética, though Leuenroth refused a partnership position in the company, desiring to preserve his anti-capitalist principles, and instead remained only an employee. Waldemar was put in charge of soliciting advertisements from neighborhood businesspersons, while Edgard managed all of the office work ${ }^{140}$. Regardless of the capitalist administrative tendencies of Folha, the newspaper added an element of social consciousness to Leuenroth's work in that it sought to defend the interests of the residents of Brás, which was now evolving into a veritable industrial powerhouse, supplying housing and providing jobs for a large number of working-class Italian immigrants.

Liane Maria Bertucci cites a December $23^{\text {rd }}$ front-page article from 1900 on the public health of the neighborhood that praised a state government plan to accelerate the building of drainage pipes for the neighborhood. Leuenroth had actively campaigned on behalf of public health conditions for Brás during the bubonic plague that hit São Paulo in 1899 , claiming on October $22^{\text {nd }}$ that the state government needed to do much more in the way of preventative measures to handle the scourge ${ }^{141}$. On November $12^{\text {th }}$ of that year, Leuenroth expounded more generally on the housing crisis: "In all of the neighborhoods

\footnotetext{
${ }^{139}$ Khoury, "Edgard Leuenroth: Uma vida e um arquivo libertários", p. 119

${ }^{140}$ Ibid. Eugênio Leuenroth remained in control of $A$ Ecléctica well into the late 1920s, working on campaigns for Ford, among others. His son, Cícero, would found the famous Propaganda Standard. See "Master of His Market". Time Magazine. Oct. 30th, 1964.

${ }^{141}$ Liane Maria Bertucci, "Cidade, Saude e Militância Operária. São Paulo, Início do Século XX". Conference Proceeding, 49 Congreso Internacional del Americanistas (ICA). Quito, Equador. 7-11 Jul, 1997.
} 
of the big city there are collective dwelling houses [cortiços], and this is a general rule, for even in the richest and most luxurious quarters, houses with four families and more are to be found at each step"142.

It is tempting to look at Leuenroth's positions on public health in Folha do Braz as a kind of eugenics-driven hygiene campaign. Indeed, that many anarchists and positivists shared similar philosophical roots that led them to tread dangerously close to one another, an issue addressed in the next chapter, might add weight to this temptation. However, Teresa Meade notes that while positivists throughout Brazil were gentrifying urban cores and enacting forced vaccination campaigns aimed at reclaiming urban space for the elite, marginalizing the poor to the political and geographic outskirts of the city, people like Leuenroth were engaged in the reclamation of urban space on behalf of the working poor $^{143}$.

Rather, we can use this brief examination of one issue that Leuenroth grappled with in Folha to assess the development of his belief system. Clearly, he had not yet developed his militant anarchism at the age of nineteen: indeed, he advances an obviously statist position. However, we can see a nascent social democracy and class-consciousness in his writing. The problem with the state at this point in his life, is that it is not providing the services that it ought to, in his mind, not even to those in a higher social class. Leuenroth's framing at this young age is clever: whether knowingly or not, he takes the local, predominantly working-class concerns of Brás, and links them to a citywide issue affecting all residents. Thus, regardless of his 'authentic' anarchist credentials, it is

\footnotetext{
${ }^{142}$ Qtd in Lúcio Kowarick and Clara Ant "One Hundred Years of Overcrowding: Slum Tenements in the City". In Social Struggles and the City: The Case of Sao Paulo. Ed. Lucio Kowarick. New York, NY: Monthly Review Press. 1994. p.64.

${ }^{143}$ Teresa Meade. 'Civilizing' Rio: Reform and Resistance in a Brazilian City, 1889-1930. University Park, PA: Pennsylvania State UP. 1997. pp. 3-7
} 
obvious that Leuenroth was learning how to construct an effective political discourse to advance the interests of the residents in his neighborhood, as well as his own. While most authors pin Leuenroth's direct engagement with left politics on events that would come three years later, it is clear from his writings in Folha do Braz that he began formulating his beliefs much earlier, if yet in undeveloped form.

Leuenroth would continue publishing Folha do Braz until 1901. In that same year, Neno Vasco (born Gregorio Nazianzeno Moreira de Queirós Vasconcelos), a recent graduate of law from Coimbra University, emigrated from Portugal to São Paulo ${ }^{144}$. Within a short time, he joined a group of Italian anarchists in the city, likely in Brás, and became active within the anarchist community ${ }^{145}$. Around this time, Leuenroth's mere interest in the 'social question', according to Rodrigues, developed into an "infection" and he began reading the anarchist classics (notably Kropotkin, Bakunin and Proudhon). He met Vasco, though it is not exactly clear when, and with his help, expanded his knowledge of sociology and Portuguese ${ }^{146}$. Leuenroth's socialization as a radical political actor was nearly complete. Over the next two years, he would collaborate with O Alfa, based out of Rio Claro, via telegraph until finally taking a more prominent role in the struggles for the liberty and equality of all in early twentieth century São Paulo.

\section{III}

Though, as we have seen, Leuenroth began his engagement with journalistic activism and left politics much earlier, the dedication, diligence and fervor of the anarchist activism that Leuenroth has come to be known for really began in 1903.

\footnotetext{
${ }^{144}$ A. Thomas Lane, Ed. Biographical Dictionary of European Labor Leaders. Westport, CT: Greenwood. 1995. p. 692

145 John F.W Dulles, Anarchists and Communists in Brazil, p. 9

${ }^{146}$ Edgar Rodrigues. "Edgard Leuenroth, 1881-1968". In Against All Tyranny! Essays on Anarchism in Brazil. Ed. Paul Sharkey. Berkeley, CA: Kate Sharpley Library. 2003. p. 19
} 
Rodrigues points out that Leuenroth was responsible for setting up the São Paulo

Typographical Centre, which was transformed in a merger with another printing association into the União dos Trabalhadores Gráficos (UTG) on March $13^{\text {th }}, 1904^{147}$.

Angela Birardi and Gláucia Rodrigues Castelani describe the aims and purposes of the labor union as directed at:

obtaining a reduction in working hours, regulating the admission of apprentices in the workshops, stimulating the spirit of solidarity between the workers, the installation of a library that could be frequented by those associated with the union, the publication of a periodical that would deal with class interests and the progress of the graphic arts, [and] to provide moral support to members, so they weren't mistreated in the workshops ${ }^{148}$.

Leuenroth would play a major role in this union, becoming its librarian, and founder and editor of its flagship paper, $O$ Trabalhador Gráfico ${ }^{149}$ launched on May $5^{\text {th150 }}$, which was designed to act as a propaganda vehicle that would establish a sense of unity and classconsciousness between the graphical workers and other members of the working class ${ }^{151}$.

Leuenroth was also involved in a socialist circle in 1903, garnering his academic credentials in Marxism alongside his experience in the labor movement. However, Yara Aun Khoury notes that he collected and read works that supported the perspective of the creative liberty of historical subjects over those that practiced historical determinism ${ }^{152}$. Because of his propensity towards the development of individual personal responsibility and knowledge ${ }^{153}$, which I argue results from the factors of his childhood experiences

\footnotetext{
${ }^{147}$ Ibid.

${ }^{148}$ Angela Birardi e Gláucia Rodrigues Castelani "Gráficos: os artesãos das palavras" Klepsidra. Ano III, Num. 13. Outubro-Novembro 2002. p. 1-2; See also Edgar Rodrigues. Socialismo e Sindicalismo no Brasil. Rio de Janeiro: Laemmert. 1969. p. 113 for a more detailed description of the goals of the UTG.

${ }^{149}$ John F.W. Dulles, Anarchists and Communists in Brazil. p. 15

${ }^{150}$ Edgard Rodrigues. Nacionalismo \& Cultura Social. Rio de Janeiro: Laemmert. 1972 p. 438

${ }^{151}$ Birardi e Rodrigues Castelani. "Gráficos: os artesãos das palavras", p. 2

${ }^{152}$ Yara Khoury. "Edgard Leuenroth: Uma vida e um arquivo libertários". Rev. Bras. de Hist. v. 17, n. 33. 1997. p. 116

${ }^{153}$ Ibid.
} 
described in section I and II, he was "converted" to anarchism by the poet Ricardo Gonçalves by $1904^{154}$.

Thus, the years Leuenroth was between 21 and 23 (1902-1904), represent his 'coming of age' in political terms. From an isolated young print worker interested in literary criticism and hobby publishing, Leuenroth developed into a major intellectual and professional contributor to the São Paulo labor movement, to the anarchist cause, and to the expansion of his own profession. Upon the formation of the UTG, Leuenroth would begin a ceaseless campaign of organizing and creating, collaboration, publishing, editing, and congress participation that would effectively last until his death.

One can look to a number of explanations for this explosion of activity. From the point of view of individual psychology, and to a lesser extent cognitive processes, one could argue that the meaning that being part of a collectivity offers leads to a boost of confidence for participants, allowing them to take on social roles they might not otherwise engage in ${ }^{155}$. Without a doubt, Leuenroth had played a leadership role in many of the ventures he had been involved with up to this point. However, these mostly smallscale collaborations with friends and family members stopped just short of allowing Leuenroth to form a broader social solidarity ${ }^{156}$. With his participation in UTG,

\footnotetext{
${ }^{154}$ Antonio Arnoni Prado, "Cenário para um retrato: Ricardo Gonçalves". In: Libertários no Brasil: Memória, Lutas, Cultura. Ed. Antnio Arnoni Prado. São Paulo: Editora Brasiliense. 1986. p.112. Antonio Arnoni Prado writes of Gonçalves, "[he] is... a paradoxical example of a militant who, without bending to the powers that be, had amputated his non-conformism on his own initiative..." p. 110. There are considerable problems with this accounting of Leuenroth's 'conversion' to anarchism, namely due to the often anachronistic claims that other scholars make regarding Leuenroth's identification with anarchism on one hand, and the moment of his life where he formally takes the cause up on the other. Likely, to varying degrees, Leuenroth believed in the key tenets of anarchism for some time. However, in his relationships with his close friends Neno Vasco and Ricardo Gonçalves, he was given the encouragement and selfconceptualization that he needed to frame these principles as a coherent core of his identity.

${ }^{155}$ For the roots of these ideas, see for example the works of Max Weber, George Herbert Mead, and Herbert Blumer.

${ }^{156}$ For an overview of the topic of solidarity, see Graham Crow. Social Solidarities: Theories, Identities and Social Change. Philadelphia, PA: Open University Press. 2001.
} 
Leuenroth would become part of a larger collectivity that would graft its own shared meanings onto its members. Perhaps, as Erich Fromm posited in The Escape from

Freedom,

there is only one positive, productive solution for the relationship of individualized man with the world: his active solidarity with all men and his spontaneous activity, love and work, which unite him again with the world, not by primary ties, but as a free and independent individual [sic] ${ }^{157}$.

Leuenroth's involvement in UTG, especially given the fact that one of its central precepts was to provide moral support and boost member solidarity, would give him the encouragement he needed to excel in his social activities, including the establishment of the union itself. This mutual reinforcement would provide the impetus for Leuenroth's activism that continued into his later life, allowing and encouraging him to continue his tireless activism $^{158}$.

Another explanation comes from his interactions with capitalist society and its brutalization of the human experience, which was increasing in pace and fervor in early twentieth century São Paulo. As mentioned briefly before, working and living conditions in the city were horrid for the majority of the working class. One widely quoted report describing the living conditions in the cortiços by Dr. Alfredo Leal de Sá paints a vivid picture:

they are habitations... where at night in the closed environment the room contains air for only onethird as many people as crowd into it; where the daily provisions, hanging from the walls, add their perfume to the foul-smelling atmosphere; [and] where coal or kerosene stoves blacken the walls, [leaving the occupants] asphyxiated and sickened... 159

\footnotetext{
${ }^{157}$ Erich Fromm. Escape from Freedom. New York, NY: Henry Holt \& Company. 1994. p. 35

${ }^{158}$ Interestingly, though outside the scope of this chapter, Leuenroth had a breakdown just after the Third Labor Congress of 1920 that forced him to disengage from public life for a short time. See John F.W. Dulles. Anarchists and Communists in Brazil, p. 138

${ }^{159}$ Qtd in Teresa A. Meade. 'Civilizing' Rio: Reform and Resistance in a Brazilian City, 1889-1930. University Park, PA: Pennsylvania UP. 1997. p. 126
} 
The wage situation was hardly better. Edgar Rodrigues maintains that salaries in São Paulo in 1886 ranged from between $2 \$ 000$ and $4 \$ 000$ mil-réis ${ }^{160}$ a day ${ }^{161}$, while Robert $\mathrm{H}$. Mattoon Jr. states that the average wage for linemen in the railway industry rose only $1 \$ 000$ mil-réis between 1875-1910, during which the currency was quite volatile ${ }^{162}$. Both Warren Dean and Sheldon Maram demonstrate that in 1919, the food bill alone for a family of seven outstripped a worker's income by four times. Thus, it is not surprising that a 1901 survey found children as young as five working in factories ${ }^{163}$. Joel Wolfe's survey of 31 textile mills in 1912, 29 of them in São Paulo city, and many in Brás, shows that over thirty percent of workers were under the age of $16^{164}$. Thus, given Leuenroth's experiences as a worker, and as a resident of an industrial neighborhood, it is not surprising that Edgar Rodrigues summarizes his political awakening as resulting from a "run up against the class struggle arising out of the widening social inequality in São Paulo..."165

The editors of Dealbar expand on this idea in a brief obituary of Leuenroth, offering a more phenomenological framing:

It was human pain that always distressed him, social inequality caused him to repulse, and it was because of this that, when young [and] youthful still, at the side of the great poet Ricardo Gonçalves, he embraced anarchist philosophy. And to this doctrine, he was given to entirely,

\footnotetext{
${ }^{160}$ The basic unit of currency at the time was called the mil-réis, or a thousand réis, and is written as above. The estimated nominal exchange rate per $1 \$ 000$ mil-réis, averaged between 1900 and 1917, is 3.911 per U.S. Dollar. See: "Nominal Exchange Rate for Brazil, 1900-1917". Oxford Latin American Economic History Database. Oxford University. 2008.

${ }^{161}$ Edgar Rodrigues. Trabalho e Conflito: Pesquisa Histórica, 1900-1935. Rio de Janeiro: Gráfica Editora Arte Moderna. 1977. p. 40

${ }^{162}$ Robert H. Mattoon Jr. "Railroads, Coffee, and the Growth of Big Business in São Paulo, Brazil". Hispanic American Historical Review. Vol. 57, No. 2. 1977. p. 292.

163 Joseph Love. São Paulo in the Brazilian Federation, pp. 87-88

${ }^{164}$ Joel Wolfe. Working Women, Working Men: São Paulo and the Rise of Brazil's Industrial Working Class, 1900-1955. Durham, NC: Duke UP. 1993. p. 8

${ }^{165}$ Edgar Rodrigues. "Edgard Leuenroth, 1881-1968". In Against All Tyranny! Essays on Anarchism in Brazil. Ed. Paul Sharkey. Berkeley, CA: Kate Sharpley Library. 2003. p. 19
} 
without ever complaining of the annoyances, the persecutions, and the following imprisonments he suffered ${ }^{166}$.

Regardless of the direction of the causal relationship that motivated Leuenroth to become such a major force in the labor movement and in anarchist circles, it is clear that the socio-economic context of urban Brazil at the time played a decisive role.

Leuenroth's activity would reach a feverish pitch in the latter half of the first decade of the $20^{\text {th }}$ century. In November of 1905 , he would sign on to administer the newspaper A Terre Livre, with Neno Vasco as the director, and Manuel Moscoso as a collaborator $^{167}$. The first issue would appear on December $30^{\text {th }}$ of that same year, and would continue on a fortnightly basis until April of 1907 when the office moved to Rio de Janeiro and began weekly publication, with José Romero as administrator ${ }^{168}$. The first edition of the paper laid out the ideological orientation and the themes to follow:

We are socialists and anarchists. As socialists, we attack the institution of private property and the values it has as its base... Subject to wage slavery, the worker, receiving in exchange for his labor only a small part of what is produced, sees his possibilities for consumption extremely limited, he is not able to buy. We want a society that finally has to ensure to each their whole development. We take the name of anarchists and libertarians because we are enemies of the state, that is, of the whole of the political institutions that impose their interests and their will on everyone, masked or not as the popular will ${ }^{169}$.

This clear manifesto laid out the path that A Terre Livre would follow throughout its publication lifespan. The paper would have a large influence on the anarchist movement, with Neno Vasco even introducing a spelling modernization that would later be adopted by the Brazilian Academy of Letters ${ }^{170}$. Moreover, the newspaper ran a number of articles on the revolutionary struggles inside Russia in 1906, asking for financial support for the Russian people, which inspired Peter Kropotkin to write a personal letter of

\footnotetext{
${ }^{166}$ Dealbar, p. 1

${ }^{167}$ Edgar Rodrigues. "Pequena História da Imprensa Social no Brasil”. Comunicaço Comunitária. 1996. p. 7

${ }^{168}$ Edgar Rodrigues. Socialismo e Sindicalismo no Brasil. Rio de Janeiro: Laemmert. 1969. p. 106

${ }^{169}$ Ibid. pp. 106-7

${ }^{170}$ John F.W. Dulles. Anarchists and Communists in Brazil. p. 9
} 
thanks ${ }^{171}$. It would cease publication with its $62^{\text {nd }}$ volume when Vasco left Brazil for Portugal after the establishment of a Republican government there on October $5^{\text {th }}$, $1910^{172}$

In 1906 , at the young age of 25 , Leuenroth took part in the first congress of the Confederação Operária Brasileira (COB) held in Rio de Janeiro from April $15^{\text {th }}-20^{\text {th }}$. Though its existence was somewhat precarious during its first ten years, the COB's emergence represented the first national labor organization that had a considerable impact on the political economy of the country ${ }^{173}$. According to Robert J. Alexander, the principles of the $\mathrm{COB}$ are best described as anarcho-syndicalist. In contrast to the stated goals of A Terre Livre, the COB did not have anarcho-communism, or any other utopian vision, as its focus. Rather the goals would be very similar to the UTG, if with enhanced research and advocacy functions ${ }^{174}$. The COB would gather statistics on the Brazilian labor movement to be used to publicly defend the economic position of workers via the publication of its propaganda organ, $A$ Voz do Trabalhador $^{175}$. The COB also refused to dictate a line that its members were to adhere to, though it sought to influence their choices by counseling them on certain issues. Generally speaking, it refused to have paid employees as well, opting for voluntary association instead ${ }^{176}$. Edgard Leuenroth's role at

\footnotetext{
${ }^{171}$ Paul Avrich. Anarchist Portraits. Princton, NJ: Princeton UP. 1988. p. 258

${ }^{172}$ Edgar Rodrigues. "Pequena História da Imprensa Social no Brasil". Comunicaço Comunitária. 1996. p. 7

${ }^{173}$ Paulo Sérgio Pinheiro \& Michael M. Hall. A Classe Operária no Brasil, 1889-1930. Vol. 1 -O Movimento Operário. São Paulo: Editora Alfa Omega. 1979. p. 41, 44

${ }^{174}$ Again, great discrepancies in the literature exist over just what the COB stood for. In contrast to the viewpoints presented above, Edgar Rodrigues claims that the designs of the confederation were to produce working-class cultural projects that would result in no less than the "destruction of the state, to end the regime of rich and poor, exploiters and exploited, to reconstruct on top of the ruins of the old bourgeois system a New Society, where all have equal rights and duties". "Pequena História da Imprensa Social no Brasil", p. 8

175 Robert J. Alexander. A History of Organized Labor in Brazil. Westport, CT: Praeger. 2003. p. 14

${ }^{176}$ Ibid. p. 15
} 
the congress is unclear, though he acted as a delegate for the Federação Operária de São Paulo, which represented six unions in the city.

These brief descriptions of some of the projects Leuenroth participated in demonstrate the subtle differences in the ideology that he was grappling with at a relatively young age. His ability to compromise on what he viewed as the right course of action with what others wanted demonstrates Leuenroth's flexibility as a social actor. Indeed, Yara Khoury has highlighted this is a hallmark of his personality.

A marked characteristic of Edgard Leuenroth's militancy is his tolerance and flexibility in relation to other anarchist tendencies, [seen] in his intermediation of others in the anarchist struggle, he intermediated [among] those that caused controversy in the movement not only with other currents in organized labor, but within the anarcho-syndicalists themselves ${ }^{177}$.

His successes in organizing and influencing so many people could easily be accredited to this flexibility. However, it also might go some way in explaining his lifelong adherence to anarchist principles. Through his tolerance and understanding of the value positions of others, Leuenroth would be forced to constantly assess his own beliefs against theirs, making those that withstood that critical scrutiny stronger, and leading him to discard those that did not in favor of the better ones. This dialectic would necessarily involve a certain amount of self-reflection, keeping Leuenroth focused on his core beliefs.

Beginning on May $1^{\text {st }}$, 1906, Leuenroth worked as an editor for Luta Proletaria ${ }^{178}$, the propaganda organ of the Federação Operária de São Paulo, which would play a central role in the rail workers strikes of that year. On that same day, in celebration of May Day, Leuenroth went out to Jundiaí, a city sixty kilometers north of São Paulo, where he gave a long speech on the resolutions and rights resulting from the first

\footnotetext{
177 Yara Khoury. "Edgard Leuenroth: Uma vida e um arquivo libertários". Rev. Bras. de Hist. v. 17, n. 33. 1997. p. 123

${ }^{178}$ Also referred to as "A Luta Operária”. see Rodrigues, Nacionalismo \& Cultural Social, p. 427
} 
Congress of the $\mathrm{COB}^{179}$. Later that month, workers of the Paulista Railway Company in that city would go on strike in protest against wage decreases and union busting, and on the $17^{\text {th }}$ of May, six hundred textile workers would join the strike ${ }^{180}$. The result was severe repression by state police, with a number of people losing their lives during clashes $^{181}$. The Federação Operária was the first organization to come out in support of the striking workers against the violence of the state police, followed by the worker's own Liga Operária ${ }^{182}$. Leuenroth was extremely active in condemning state repression of strikers, whether writing, editing, or publishing articles and manifestos in A Terre Livre, Comércio de São Paulo, and in Luta Proletaria ${ }^{183}$.

Leuenroth would continue his involvement in the anarchist press, founding and acting as director-general of the weekly, Folha do Povo. Its first issue would appear on July $12^{\text {th }} 1908$ with the objective of "defending the interests of the people"184 . It was shortly after this as well, around the age of 27 , that Leuenroth became active in pedagogy in Brazil. On October $12^{\text {th }}, 1909$, Francisco Ferrer, the great Spanish educator and pedagogical theorist was brutally murdered by a firing squad after a fabricated trial ${ }^{185}$. The ideas that he propagated claimed that education needed to address all aspects of the human experience, and needed to view human beings as "a single energy, which sees, loves, and applies a will to the prosecution of what [it] has conceived" 186 . More practically, Ferrer and his followers sought to provide a radical rationalist and secular

\footnotetext{
${ }^{179}$ Edgar Rodrigues. Socialismo e Sindicalismo no Brasil. Rio de Janeiro: Laemmert. 1969. p. 142

${ }^{180}$ Dulles, Anarchists and Communists in Brazil, p. 20

${ }^{181}$ Ibid. p. 21

${ }^{182}$ Edgar Rodrigues. Trabalho e Conflito: Pesquisa Histórica, 1900-1935. Rio de Janeiro: Gráfica Editora Arte Moderna. 1977.p. 91

${ }^{183}$ See Ibid. pp. 93-99

${ }^{184}$ Edgar Rodrigues. Nacionalismo \& Cultura Social.p. 431

185 Joseph McCabe. The Martyrdom of Ferrer. London: Watts \& Co. 1909. pp. $90-96$

${ }^{186}$ Qtd. in Murray Bookchin. The Spanish Anarchists: The Heroic Years, 1868-1936. Oakland, CA: AK Press. 1998. pp. 117-18
} 
education to members of the working class in the hopes that they would be able to lead a future revolution. Leuenroth participated in the early 1910 s in the establishment of the Escola Nova (founded in 1909) and the Escola Moderna (founded in 1912) alongside his close friends, notable Brazilian educators João Penteado and Florentino de Carvalho ${ }^{187}$.

It is easy to see why Leuenroth was attracted to the idea of radical schools. Education formed the core of his anarchist beliefs, since the creation of a future society founded on individual responsibility required the development of individual capacities to reason, to empathize, to compromise, and to aid. Despite the seeming diversity of Leuenroth's activities, education was ever-present at the core of his activism. In his journalism, Leuenroth always sought to raise awareness on critical social issues, aiming to hold elites accountable for their political practices, and ensuring that the masses understood those same practices. Hence, his tireless forays into the public sphere were not just about the content of his argumentation, but rather about the formation of arguments designed for implicit pedagogy. In his organizing efforts, Leuenroth valued hands on involvement by all members, opting for loose federative bodies over hierarchal centralized organizations. In almost all of the unions he took part in organizing, some form of education was explicitly stated in the guiding principles. This latest endeavor to engage directly in pedagogy merely reaffirmed a strong value and commitment to a social practice Leuenroth had engaged in all of his life.

Beginning on October $17^{\text {th }}, 1909$, not long before his $28^{\text {th }}$ birthday, Leuenroth would take up the direction of a periodical that would earn him many more enemies than his prior publications had. A Lanterna was an anti-clerical periodical founded by Dr.

${ }^{187}$ Yara Aun Khoury. "Edgard Leuenroth: Uma vida e um arquivo libertário". Rev. Bras. de Hist. v. 17, no. 33. 1997. p. 121 
Benjamin Mota in March of 1901, and Leuenroth's involvement would see him publish 293 editions over seven years until publication ceased temporarily in 1916 due to Leuenroth's desire to form another paper ${ }^{188}$. The origins of $A$ Lanterna are grand, boasting a circulation of ten thousand copies distributed free of charge, with a first issue that prophetically stated, "We are only a few men. Are we ten? Are we twenty? What does it matter? We shall be a legion tomorrow, when everyone, knowing how clericalism is deleterious, how Jesuitism is malign, how religious hypocrisy brutalizes the people, will decide to join our ranks" ${ }^{\prime 189}$.

Perhaps the most notorious outcome of Leuenroth's involvement with A Lanterna, was what has come to be known as the Idalina Affair. A priest, Faustino Consoni, was accused of raping and ultimately murdering a young child, Idalina Stamato, who had recently arrived at the São Cristóvão orphanage that he was the director of ${ }^{190}$. On February $17^{\text {th }}, 1911$, A Lanterna launched a special edition conjointly with the anarchocommunist Italian-language periodical La Battaglia which asked the simple questions and offered the provocative response, "Where is Idalina? Who killed Idalina? It was

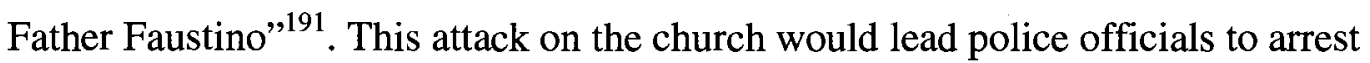
Leuenroth for the first time, along with a hundred other people associated with a variety of anarchist periodicals across the state ${ }^{192}$. Despite Benjamin Mota's demand for habeas

\footnotetext{
${ }^{188}$ Edgar Rodrigues. Nacionalismo \& Cultura Social, p. 425.

${ }^{189}$ Qtd. in Dulles. Anarchists and Communists in Brazil. p. 14-5

${ }^{190}$ Marcos Rezende. "Anarquismo, Igreja Pastoral do Imigrante”. Revista Expressão. No. 1. 2000; Dealbar, p. 1

${ }^{191}$ Isabelle Felici. Les Italiens dans le mouvement anarchiste au Brésil, 1890-1920. Thèse de Doctorat: Université de la Sorbonne. 1994. p. 181, 414 fn.1151; Dealbar, p. 1

${ }^{192}$ Ibid. 181
} 
corpus to be respected on March $13^{\text {th }}$, Leuenroth would remain in prison until Evaristo de Morais would work to free him ${ }^{193}$.

A Lanterna would also have the honor of publishing a letter on October $12^{\text {th }} 1912$ that would have José Oiticica, a literary critic, philosopher and son of a northeastern senator, declare himself an anarchist for the first time. Oiticica would reveal his longbrewing anarchist tendencies in a letter commemorating the third anniversary of the death of Francisco Ferrer ${ }^{194}$. From that moment on, Oiticica would be a tireless campaigner for the anarchist cause in Rio de Janeiro, like Leuenroth, maintaining true to his anarchist beliefs for the rest of his life ${ }^{195}$.

From September $9^{\text {th }}$ to $13^{\text {th }}, 1913$, Leuenroth attended the Second Congress of the $\mathrm{COB}$, which gathered together fifty-nine associations and organizations, most from Rio de Janeiro, São Paulo, Minas Gerais and Rio Grande do Sul ${ }^{196}$. In contrast with the outcome of the first Congress, this meeting resulted in a more clearly defined vision of the direction in which Brazilian society should evolve ${ }^{197}$. The COB proclaimed that

...the State, with its institutions of force and violence, constitutes an enormous barrier between the working class and the capitalist class, a barrier that is necessary to destroy through an economic transformation that will make disappear the class antagonisms that convert men into devourers of men, and free of any kind of centralizing or authoritarian organism, and bring about the establishment of a people of free producers, so that at last the servant and the master, the aristocrat and the plebian, the bourgeois and the proletarian, the owner and the slave, who with their economic and social differences have bloodied history, will finally embrace as true brothers ${ }^{198}$.

Furthermore, the $\mathrm{COB}$ agreed upon a federative style of trade union organization that demanded the maximum amount of individual autonomy for workers, for unions, and for

\footnotetext{
${ }^{193}$ Ibid. Marques da Costa. Ano. III, n. 6. May 2007.

${ }_{195}$ Dulles, Anarchists and Communists in Brazil. p. 31

${ }^{196}$ Robert J. Alexander. A History of Organized Labor in Brazil, p. 17

${ }^{197}$ Though see fn. 174 above for a contrasting interpretation.

${ }^{198}$ Qtd. in Alexander. A History of Organized Labor in Brazil, p. 17
}

${ }^{194}$ Dulles, Anarchists and Communists in Brazil. p. 30. For more detailed information on Oiticica's contributions to the anarchist movement, see Rodrigues. Socialismo e Sindicalismo no Brasil. Pp. 312-18. Also see Milton Lopes, "José Oiticica: Uma Existência Pela Ação Direta". Boletim do Núcleo de Pesquisa 
federations within the confederation. Leuenroth was able to leave his stamp on the COB despite the increasing interest in a more tight-knit system of centralized union direction by some members. In addition, at this Congress, Leuenroth's brother João, who was now living in Rio de Janeiro, also participated as the treasurer ${ }^{199}$.

Foreshadowing this clash of different ideas over the best way to overthrow capitalism and the state, Leuenroth became involved with A Guerra Social, a Rio de Janeiro-based weekly directed by a rising star in the anarchist movement, Astrojildo Pereira $^{200}$. Different accounts place Leuenroth's involvement with A Guerra in roles as diverse as founder, director, editor, and collaborator ${ }^{201}$. However, the real significance would be his relationship with Pereira. Leuenroth had recently met Pereira at the Second Congress of the COB, where Pereira, then only 23 years old, acted as the assistant to its secretary general, Rosendo dos Santos ${ }^{202}$. Pereira, born in Rio Bonito in the state of Rio de Janeiro, was an ardent admirer of both Brazil's literary giant Machado de Assis, and Peter Kropotkin's The Conquest of Bread ${ }^{203}$. Though he would play an important role in the anarchist movement throughout the 1910 s, he would eventually become the first founder of the Brazilian Communist Party ${ }^{204}$. It was at this time that Leuenroth would also become an active contributor to the São Paulo based daily $O$ Combate edited by

\footnotetext{
${ }^{199}$ Dulles. Anarchists and Communists in Brazil, p. 27

${ }^{200}$ Edgar Rodrigues. Nacionalismo \& Cultura Social. Rio de Janeiro: Laemmert. 1971. p. 457, 426

${ }^{201}$ Edgar Rodrigues puts him as a chief editor in his short biographical sketch in Against All Tyranny! , though he does not give Leuenroth any role in either the São Paulo or Rio de Janeiro A Guerra in Nacionalismo \& Cultura Social (p. 432). It is clear, based on his personal relationships with regular contributors that Leuenroth was connected to the Rio de Janeiro paper, but it appears that he was only an infrequent contributor. I was only able to find one article that Leuenroth contributed to the newspaper writing under the penname 'Frederico Brito'. "O Despertar". A Guerra Social. Ano 1, Num. 10. 18 Jan 1912. p. 2

${ }^{202}$ Dulles, Anarchists and Communists in Brazil, p. 28-9

${ }^{203}$ Ibid. 29

${ }^{204}$ Leuenroth's relationship with Pereira would turn vicious by the early 1920 s when ideological differences would lead the anarchists and communists to attack one another in their presses, though it is beyond the scope of this thesis to describe that battle here. See Dulles, Anarchists and Communists in Brazil for an in-depth accounting of the split between Leuenroth and Pereira.
} 
Nereu Rangel Pestana. By the end of 1915 , at age 34 , he would become a major force in the newspaper, through which he would play an important role in the São Paulo general strike of $1917^{205}$

Despite Leuenroth's success with A Lanterna, on November $19^{\text {th }}, 1916$, he decided to cease his involvement with it and found one of the most influential anarchist (and proletarian-directed) periodicals the city ever had ${ }^{206}$. A Plebe was launched on June $8^{\text {th }}, 1917^{207}$, and would discuss topics ranging from strikes to education, women, child labor, and even a historical accounting of the Brazilian anarchist movement up until that point $^{208}$. Its epigraph read, "by anarchism, for freedom", a clear and succinct encapsulation of what the paper stood for ${ }^{209}$. Yet the paper was not a drastic break from $A$ Lanterna. Khoury points out "To the eyes of the observer, 'A Lanterna' and 'A Plebe' complemented and supported each other, even while privileging fronts of diverse

\footnotetext{
${ }^{205}$ Ibid. p. 52; Edgar Rodrigues. "Edgard Leuenroth, 1881-1968". In Against All Tyranny! Essays on Anarchism in Brazil. Ed. Paul Sharkey. Berkeley, CA: Kate Sharpley Library. 2003. p. 20

${ }^{206}$ Edgar Rodrigues. Nacionalismo \& Cultura Social, p. 425

${ }^{207}$ Khoury notes that there is a danger when compiling a complete catalogue of newspapers liked A Plebe because it was rare for them to put their edition dates on all pages (see Yara Aun Khoury. As Greves de 1917 Em São Paulo E O Processo De Organização Proletária. São Paulo: Cortez Editora/Autores Associados. 1981. p. 11). Indeed, it seems there is even more difficulty in accurately determining the initial date of publication. In the same publication, Khoury states that A Plebe emerged in 1916 (p. 13). Gonçalves and Nascimento put that date as the $9^{\text {th }}$ of January, based on information obtained from the Arquivo Edgard Leuenroth (p. 5). In another publication by the two entitled "Jornal E Educação: A Formação Do Militante Anarquista", they put the date at June $9^{\text {th }}, 1917$. (Paper presented at the $16^{\text {th }}$ Congresso de Leitura do Brasil. July $10^{\text {th }}-13^{\text {th }}, 2007$. Campinas, SP). Dulles places this date on June $8^{\text {th }}, 1917$. (Anarchists and Communists in Brazil, p. 53), while Rodrigues ("Pequena História da Imprensa Social no Brasil". Comunicaço Comunitária. 1996. p. 9) puts A Plebe's first edition on the 6th of June, 1917. I opted for the "mean" date above. However, I am inclined to support the statistical aberrant of early January 1917 (or even late in 1916). The reason for this inclination revolves around the belief, based on biographical precedent, that Leuenroth would not likely cease publication of A Lanterna in mid-1916 without beginning another project in a reasonably quick timeframe.

${ }^{208}$ Dulles, Anarchists and Communists in Brazil. p. 53; Aracely Mehl Gonçalves \& Maria Isabel Moura Nascimento. "A Educaçã Libertária e a Imprensa Anarquista (1917-1927)".Paper delivered at IV Congresso Brasileiro de História da Educação. Goiâna, GO. November 5th - 8th, 2006. p. 5

${ }^{209}$ Edgar Rodrigues. Nacionalismo \& Cultura Social.p. 429
} 
struggles" ${ }^{210}$. Rather than view them as distinct papers - one anti-clerical, the other anticapitalist - it makes more sense to see them as flowing into one another, as the tides of the class struggle in São Paulo ebbed to make it more sensible to focus on worker organization and strike mobilization and education.

Leuenroth worked tirelessly to ensure that $A$ Plebe would reach a large audience and make an important impact on the working class. The newspaper brought together some of the most promising minds, young and old, of the anarchist movement at the time: Benjamin Mota, Astrojildo Pereira, Florentino de Carvalho, who all regularly contributed to the newspaper ${ }^{211}$. After only two years of periodic publication, A Plebe became a daily, one of the highest achievements for small independent anarchist presses ${ }^{212}$.

Khoury has called A Plebe the most important newspaper of the period for anarchist militancy in Brazil, a claim that is repeated throughout the literature ${ }^{213}$. During its publication life span, the paper was viewed the same way by colleagues of Leuenroth's. At the end of 1920, he was honored in Juiz de Fora, Minas Gerais by the Federação Operária Mineira. Through their print organ, $O$ Proletario, they lauded Leuenroth for having developed through A Plebe "so formidable a campaign that the bastions of capitalism in São Paulo felt themselves seriously threatened"214. The reasons for the success of the paper have everything to do with the São Paulo general strike of July 1917, with which A Plebe - and Leuenroth - are inextricably intertwined.

\footnotetext{
${ }^{210}$ Yara Aun Khoury. Edgard Leuenroth: Uma vida e um arquivo libertário. Rev. Bras. de Hist. Vol. 17, no. 33. 1997. p. 120

${ }^{211}$ See Yara Aun Khoury. As Greves de 1917 Em São Paulo E O Processo De Organização Proletária. São Paulo: Cortez Editora/Autores Associados. 1981.

212 "A Voz dos Operários". Fenae Agora. Ano. 5, vol. 2, Edição 30. 2002.

${ }^{213}$ Qtd. in Gonçalves \& Nascimento. "Jornal e Educação: A Formação Do Militante Anarquista", p. 3

${ }^{214}$ Qtd. in Dulles. Anarchists and Communists in Brazil. p. 148
} 
The origins of the series of strikes that took place in and around São Paulo during the summer of 1917 , are usually attributed to two thousand textile workers at the Cotonifício Créspi factory (who were refused a wage increase) initiating a work stoppage in mid-June ${ }^{215}$. Quickly, support for the Créspi strikers picked up across the city, spilling out into the interior of the state, and eventually into the city of Rio de Janeiro.

Leuenroth's role in the strike is quite clear, though it was the subject of considerable controversy, both at the time and in the subsequent literature.

In the recent literature, this controversy is represented in Joel Wolfe's claim that the anarchist labor leaders, Leuenroth included, were significantly disconnected from the rank-and-file members who carried out the strike ${ }^{216}$. Indeed, this is true, as leaders of the labor movement themselves recognized. A January $25^{\text {th }}, 1908$ article in A Luta Proletaria, edited by Leuenroth, had stated "It's a fact that the majority of our working comrades don't understand the utility of the fight between capital and labor". However, the article concluded, "We do not feel afraid, therefore, that the majority of our working brothers remain indifferent to our work of class mobilization, we do not think that, without them, our efforts will be pointless - on the contrary, we work to convince them..."217. This is a conviction that Leuenroth carried with him for his entire life, and a supporting explanation for his journalistic and educational activity.

\footnotetext{
${ }^{215}$ Dulles, Anarchists and Communists in Brazil. p. 47; Joel Wolfe. Working Women, Working Men. p. 16; John D. French. "Practice and Ideology: A Cautionary Note on the Historian's Craft". The Hispanic American Historical Review. Vol. 71, No. 4. 1991. p. 852

${ }^{216}$ See Joel Wolfe. "Anarchist Ideology, Worker Practice: The 1917 General Strike and the Formation of Sao Paulo's Working Class". Hispanic American Historical Review. Vol. 71, No. 4. 1991. pp. 809-846. As well, see the commentary for that edition which expounds on the controversy in dialogic articles between John D. French and Joel Wolfe.

${ }^{217}$ Qtd in Paulo Sérgio Pinheiro \& Michael M. Hall. A Classe Operária no Brasil, 1889-1930. Vol. 1 -O Movimento Operário. São Paulo: Editora Alfa Omega. 1979. pp. 72-4
} 
Beyond his vigorous prodding of workers through his various journalistic endeavors, Leuenroth took an active role in the strike settlement as secretary of the Comitê de Defesa Proletária. On July $14^{\text {th }}$, through Rangel Pestana, the editor of $O$ Combate, Leuenroth was asked to attend a meeting organized by a police captain, along with ten journalists, designed to seek a compromise between the workers' demands and those of industrialists ${ }^{218}$. By nine o'clock that evening, the Comitê had agreed to the industrialists' offer of a $20 \%$ increase in wages, amnesty for all strikers and those arrested during the strikes, the uninhibited right to organize, timely payment of wages, and the promise to generally improve the living and working conditions of workers ${ }^{219}$.

However, Leuenroth's role caused controversy at the time as well. The industrialists did not intend to keep these promises, even in the short term. As soon as they had regained the reigns of power, the state of São Paulo reacted in September of 1917, arresting Leuenroth as the "mastermind" of the strike. Dulles has implicitly argued that Leuenroth was effectively targeted because he had a German name at a time when anti-German sentiment spurred by Brazil's involvement in WWI was ramping up and spewing out of the mouth of government elites, such as Finance Minister João Pandiá Calógeras ${ }^{220}$. Leuenroth spent over six months in jail, before a jury acquitted him of the charge of being the "psychological-intellectual author of the general strike of 1917". His longtime friend Evaristo de Morais and José Adriano Marrey Júnior defended him at his trial $^{221}$.

\footnotetext{
${ }^{218}$ Dulles. Anarchists and Communists in Brazil, pp. 52-3.

${ }^{219}$ Joel Wolfe. Working Women, Working Men, p. 22

${ }^{220}$ Dulles. Anarchists and Communists in Brazil, p. 60

${ }^{221}$ Ibid.
} 
Some time later, Leuenroth reflected on the charge that he was the mastermind in a well-cited 1966 O Estado de São Paulo article:

The general strike of 1917 was a spontaneous movement of the proletariat without direct or indirect interference by anyone [in a labor leadership position]. It was an explosive demonstration befitting the prolonged period of tortured existence experienced by the working class at that time... Not long after that [the return to work by the strikers], I was jailed. So began my odyssey through the police stations, the object being to dodge the 'habeas corpus' orders presented when I was moved to the Public Jail, today's House of Detention ${ }^{222}$.

Clearly, Leuenroth defended what he saw as the truth and justice of the incident, and also what would have been a moment of immense pride for him. Though recent authors quibble problematically over Leuenroth's use of 'spontaneous' ${ }^{\text {,23 }}$, it really was so from Leuenroth's perspective. Beginning with Créspi, a nascent class-consciousness emerged out of the realization of the workers themselves, free of coercion or direct manipulation on the part of an anarcho-syndicalist intelligentsia. Leuenroth never shied away from the fact that he seized upon that class conscious, seeking to expand it and bear fruit from it, but he could not - and did not - claim to have started it. Nothing more would make an anarchist of Leuenroth's stripe more proud - that workers across the country were learning about their condition and taking their futures in their own hands in order to redress the blatant inequality that confronted them on a daily basis.

Unfortunately for Leuenroth, the strike movement would not pick up steam, transforming itself into an organic revolution along the way. Despite attempts in 1919 by anarchists such as José Oiticica at an "anarchist and anarchosyndicalist insurrection",224, the 1920 s would lead to what Sheldon Maram has called "A Movement Aborted", with

\footnotetext{
${ }^{222}$ Qtd. in "Edgard Leuenroth and the 1917 Strike". In Against All Tyranny! Essays on Anarchism in Brazil. Ed. Paul Sharkey. Berkeley, CA: Kate Sharpley Library. 2003. pp. 21-3.

${ }^{223}$ I am thinking here primarily of Joel Wolfe's Working Women, Working Men. p. 20

${ }^{224}$ Robert J. Alexander. A History of Organized Labor in Brazil. p. 25
} 
the anarchosyndicalists being forcefully displaced by the Brazilian Communist Party ${ }^{225}$. The 1930s would bring brutal repression at the hands of the commanding President Getúlio Vargas and his imposed 'fascist' unions. The brief interregnum between the end of Vargas' Estado Novo and the imposition of military dictatorship in 1964 would not leave much room for the anarchosyndicalists to build up their former strength.

Still, Leuenroth stayed committed to his beliefs for all of his remaining years. While other political activists turned to academic positions in literature and culture ${ }^{226}$, to communism, or to democratic politics, Leuenroth remained true to anarchist ideals and anarchosyndicalist organization until the end of his life, maintaining his avid involvement in journalism. This biography ends here with the formative years, but Leuenroth's is a life that would continue in richness until his death on September $28^{\text {th }}, 1968$.

What can we make, or rather, what should we make of this partial biography in light of the preceding chapter? It is clear to me that Leuenroth's childhood upbringing and his adolescence did have some impact on his later life. Most clearly, we can see the roots of his ideological beliefs rising from his constant exposure to divergent, if not 'radical' views based on his observations of important figures in his life such as Estevão Estrêla, the senior staff at $O$ Comércio, and his contacts with intellectuals such as Neno Vasco and Ricardo Gonçalves. I have also tried to demonstrate the more controversial foundations for his ideological leanings, such as the specific ecological and geographic experiences he had, the historical tropes that drove the state and regional culture where he

\footnotetext{
${ }^{225}$ See Sheldon L. Maram. "Labor and the Left in Brazil, 1890-1921: A Movement Aborted". Hispanic American Historical Review. Vol. 57, No. 2. 1977. pp. 254-272

${ }^{226}$ For example, Astrojildo Pereira, when he was dismissed as secretary-general for the PCB in 1931, became an ardent advocate of a new Brazilian cultural policy. See: "The Knight of Wisdom". Pesquisa FAPESP. Vol. 70. Nov. 2001.
} 
lived, and his contact with alternative forms of social and labor organization. These are much more difficult to pin directly onto Leuenroth's biography, especially in a causal way, but I do believe firmly that they influenced his frame of consciousness.

Other aspects of Leuenroth's identity do not lend themselves so neatly to dissection. Why, for example, did Leuenroth remain committed to anarchist beliefs his entire life, once he had decided upon them as a defining feature of his identity? I posit above that this might have something to do with Leuenroth's personality traits: his willingness to be flexible in his social interactions required him to confront alternatives to his own beliefs, forcing him to constantly reflect on whether or not these were logically sound, empirically grounded, morally valid, etc. I believe, somewhat paradoxically, that this constant reflection led him to formulate a solid 'core' of beliefs that necessarily would have taken up more space in the development of his ideological identity. Other readings might be found: some might argue that his continued commitment to anarchism reflected his desire to be logically consistent (or wholly 'rational'). Others could argue that his refusal to change his beliefs was the result of lack of self-reflection. Whatever the 'truth', this more complicated and nuanced argument requires more evidence than is currently available for the matter to be laid to rest.

My purpose in this chapter has not been to provide a definitive answer to the questions I raise in both my introduction and in Chapter 1. Indeed, this goes against the grain of the larger argument I am making in this thesis. Rather, I wanted to begin the dialogue on a desperately understudied personality in Brazilian history by grappling with deep and controversial issues and raising points of contention in the literature around which continued debates need to occur. I hope I have addressed some of these in this 
chapter, but I know there are many more that are 'silenced' in this thesis that could be brought to light. My final chapter will cover the formation and growth of anarchism in Brazil at a higher level of abstraction, addressing the structural origins of the emergence of anarchism. In the process, it will relate these broad shifts to some of Leuenroth's personal experiences, as well as those of his colleagues, described in this chapter. 


\section{Chapter 3: The Structural Origins of Anarchism in Brazil}

Thus far I have explored the beliefs and biography of a single anarchist associated with Brazil's labor movement at the ideational (Chapter 1) and individual level (Chapter 2), seeking to explain what accounted for Edgard Leuenroth's interest in anarchism and prolific involvement with the labor movement. In this final chapter, I want to offer an overview of the anarchist movement in São Paulo that situates these earlier chapters in their larger structural context. I will explore some of the political, economic, social and cultural factors that contributed to the growth and formation of anarchist thinking in São Paulo between the mid-1880s and the early 1920s, trying to understand why it exploded the way it did. Effectively, I will continue my examination of Leuenroth's life, though now at a higher level of abstraction that allows me to look at the 'negative space' around his life. This chapter then, will critically explore the 'formation and growth' of the São Paulo anarchist movement by exploring a few of its structural factors, namely mass immigration, transitional industrialization, the dynamics of class relations, the character of the Old Republican State, cultural currents, and the development of a tenuous national identity. Just as in Chapter 2, I will focus my gaze roughly on the period between 1881 and 1917, leaving the reader to explore the decline of both Brazilian anarchism and the labor movement in other texts.

If biographies on individual anarchists have been extremely limited, there is no shortage of texts documenting the rise of the anarchist movement in Brazil. Two major forces in the anarchist movement provided the base for future research, Everardo Dias' História das Lutas Socias no Brasil (1962) and Edgard Leuenroth's own Anarquismo: Roteiro da Libertação Social (1963). In 1966, Azis Simão, a friend of Leuenroth’s 
published Sindicato e Estado. Samuel L. Baily would call these three texts "the best existing information on the Brazilian labor movement" in $1969^{227}$, and consequently on the anarchist movement. Edgar Rodrigues would change that with his pioneering modern research on the topic, beginning with his two-volumes - Socialismo e Sindicalismo (1969) and Nacionalismo \& Cultura Social (1972). The books take on the ambitious task of charting the history of the 'Brazilian' labor movement from 1675 to 1922, though, rife with primary sources and appendices denoting the publication length of the major leftwing periodicals in Brazil, they do so masterfully. Boris Fausto's 1976 text Trabalho Urbano e Conflito Social weaves an image of the labor movement that intersects with the contributions of anarchists between 1890 and 1920.

In English, John W.F Dulles' Anarchists and Communists in Brazil, 1900-1935 (1973) remains indispensable in its breadth of detail, while other work, such as Sheldon Maram's doctoral dissertation “Anarchists, Immigrants and the Brazilian Labor Movement, 1890-1920" (1972) and Eric Arthur Gordon's “Anarchism in Brazil: Theory and Practice, 1890-1920" (1978) provide more detailed treatments of the pre-1920 period, and a more nuanced understanding of anarchist ideology. More recently, Joel Wolfe has written on the early twentieth century in his 1993 monograph Working Women, Working Men: São Paulo and the Rise of Brazil's Industrial Working Class, 1900-1955, and a 2003 pamphlet translated by Paul Sharkey entitled Against All Tyranny! Essays on Anarchism in Brazil discusses the topic, though mostly rehashing earlier work by Edgar Rodrigues.

\footnotetext{
${ }^{227}$ Samuel L. Baily. "The Italians and the Development of Organized Labor in Argentina, Brazil and the United States, 1880-1914”. Journal of Social History, Vol. 3, No. 2. 1969-70. p. 126, fn. 10
} 
This extremely brief summary review of the key monographs and dissertations on anarchism in Brazil is solely intended to highlight the apparent maturity of the topic. While Eric Gordon lamented in 1978 that "Anarchism as a comprehensive philosophy has not been studied in its Brazilian setting,"228, one might assume that the historiography of the topic has subsequently flourished, given the strong base of knowledge from which interested scholars could draw upon. Strangely, however, this is not the case. As noted in the introduction, anarchism in Brazil in the Old Republican period remains largely understudied and one-dimensional, that is, focused on reiterating many of the same bits of information unearthed by earlier scholars. I will highlight some of those 'bits', offering, where possible, my own suggestions and arguments that might help us account for the growth of the anarchist movement.

\section{Mass Immigration, Anarchist Texts, and Homegrown Ideology}

In his 1969 doctoral dissertation, Michael M. Hall sought to uncover the causes of mass immigration to Brazil in the $19^{\text {th }}$ century by pointing to the imperial government's desire for the 'colonization' of the national territory by independent small farmers, and later, as laborers for the coffee plantations ${ }^{229}$. At first, it was primarily German immigrants who were sought, and between 1820 and 1880, nearly 54,000 arrived and settled, mostly in the southern states of Rio Grande do Sul and São Paulo ${ }^{230}$. One such immigrant was Leuenroth's father, who as we know, worked in a less traditional

\footnotetext{
${ }^{228}$ Eric Arthur Gordon. "Anarchism in Brazil: Theory and Practice”. Ph.D dissertation. Tulane University. 1978. p. 25

${ }^{229}$ Michael M. Hall. "The Origins of Mass Immigration in Brazil, 1871-1914". Ph.D Dissertation. Columbia University. 1969. p. 4

${ }^{230}$ Frederick C. Luebke. Germans in the New World: Essays in the History of Immigration. Urbana, IL: University of Illinois Press. 1990. p. 95
} 
profession for immediate immigrants, as a pharmacist in central São Paulo ${ }^{231}$. Most early German immigrants did not bring detailed anarchist doctrines with them to Brazil, nor did they immediately develop them upon arrival, mainly because anarchism was not popular in Europe until after 1850. These doctrines would take a little longer to emerge with the rapid increase in southern European immigration to Brazil beginning in the 1880s.

Between 1880 and 1900, 1,485,891 immigrants from Portugal, Italy and Spain would arrive in the country ${ }^{232}$, nearly 900,000 of which arrived in the state of São Paulo alone ${ }^{233}$.

There is some debate as to whether or not even this massive influx of immigrants actually brought anarchist ideals with them. For example, Eric Gordon suggests that it was the empty promises of the 'New World' that converted immigrants to the anarchist cause, rather than the ready-made philosophies they imported from their home countries $^{234}$. In Os Companheiros, Edgar Rodrigues, on the other hand, offers biographical fragments of many obscure, largely unknown, anarchists that imply that many immigrant anarchists had already formed their own beliefs prior to arriving in Brazil, as was the case of Leuenroth's close friend Neno Vasco ${ }^{235}$. Regardless of exactly when and why these immigrants adopted anarchism, it is clear as Rodrigues points out in

\footnotetext{
${ }^{231}$ German immigrants were recruited by the Brazilian state mostly as farmers, and they emigrated for reasons such as similarities in inheritance customs, and economic prospects. Ibid. p. 96

${ }_{232}$ Jeffrey Lesser. Negotiating National Identity: Immigrants, Minorities, and the Struggle for Ethnicity in Brazil. Durham, NC: Duke UP. 1999. p. 8

${ }^{233}$ Holloway. Immigrants on the Land, p. 179; Hall. "The Origins of Mass Immigration in Brazil", pp. 1845

${ }^{234}$ Eric Arthur Gordon. "Anarchism in Brazil: Theory and Practice". PhD Dissertation. Tulane University. 1978. p. 19

${ }^{235}$ See Edgar Rodrigues. Os Companheiros - 1. Rio de Janeiro: VJR - Editores Associados. 1994; Edgar Rodrigues. Os Companheiros 2. Rio de Janeiro: VJR - Editores Associados. 1995. Certainly this is the case with some of the 'big names' such as Giovanni Rossi, who founded the anarchist colony Cecilia in 1891. See Eric Gordon. "Anarchism in Brazil", pp. 245-57
} 
another text, that trying to escape the harsh realities of the 'social question' in Europe, they found more of the same upon arrival in Brazil, which we will discuss below ${ }^{236}$.

Translated copies of classic anarchist texts began appearing in the 1870 s and 1880s. Proudhon's On the Federative Principle appeared in Portuguese in 1874, while Kropotkin's The Place of Anarchism in Socialist Evolution was translated in $1886^{237}$. It would not take long for these to make their way to Brazil, especially given the dominant methods of transportation and communication at the time ${ }^{238}$. Railroad and shipping expansions, built to serve the coffee industry, such as the those that connected the port at Santos to the Mogiana region where Leuenroth was born, also served to transmit radical ideas at a pace and scale that Brazil had not yet seen ${ }^{239}$. According to Dulles, Bakunin was especially influential in the early development of the Brazilian anarchist movement, especially since he was well-known in both Italy and Portugal ${ }^{240}$. The fact that his books were written earlier than Kropotkin meant that the ideas contained within them had much greater exposure to the minds of the early generation of Brazilian anarchists. Others were popular including Jean Grave, Carlo Cafiero, James Guillaume, and especially Élisée Reclus $^{241}$.

However, it is false to say that the spread of anarchist ideals belonged solely to European writers and their immigrant carriers. Gordon points out that anarchism offered a perfect counterpoint to the hegemony of Catholic ideology in Brazil, commenting that

\footnotetext{
${ }^{236}$ Edgar Rodrigues. "A History of the Anarchist Movement in Brazil" in Against All Tyranny! Essays on Anarchism in Brazil. Trans. Paul Sharkey. Berkeley, CA: Kate Sharpley Library. 2003. p. 2

${ }^{237}$ Ibid. p. 13

${ }^{238}$ Edgar Rodrigues. Os Anarquistas: Trabalhadores Italianos no Brasil. São Paulo: Global Editora. 1984. p. 16

${ }^{239}$ For more on this, see Steven Topik and Mario Samper. "The Latin American Coffee Commodity Chain: Brazil and Costa Rica", pp. 124-7

${ }^{240}$ Dulles. Anarchists and Communists in Brazil, pp. 5-7

${ }^{241}$ Rodrigues. Os Anarquistas, p. 16
} 
...the anarchist movement achieved its greatest proportions in Catholic countries precisely because workers (and peasants in some of them) recognized the hypocrisy of the Church's politics but yearned for similarly embracing moral guidance, seeking to proselytize their views among their fellow sufferers ${ }^{242}$.

Hence, if the earliest ideas on anarchism were only arriving with regularity in Brazil in the $1880 \mathrm{~s}$ in the form of translated texts and the political views of recent immigrants, the general dissatisfaction with the Brazilian empire, its intense centralization of authority, brutal living and labor conditions, and coercive and restrictive social and religious mores aimed at preserving "order and property" provided fertile ground for dissent ${ }^{243}$.

Earlier on, beginning in the 1850 s, there were also intellectual currents eagerly seized from Europe, which, reformulated for the local context, drove debates on how to rethink Brazilian society. Positivism was one such current that had a major impact on the Brazilian intelligentsia, by providing a clear pathway to modernization with its emphasis on progress and social manipulability ${ }^{244}$. Hence, it is not surprising that intellectuals throughout the country accorded thinkers such as Herbert Spencer prominence ${ }^{245}$. It is surprising though, at least at first glance, that early anarchists and libertarians in Brazil also hailed Spencer. Boris Fausto notes that Spencer paradoxically figures in the anarchist writings as a foundational inspiration, alongside Bakunin, Proudhon, and

\footnotetext{
${ }^{242}$ Gordon. "Anarchism in Brazil", p. 12-3

${ }^{243}$ Boris Fausto. A Concise History of Brazil. Trans. Arthur Brakel. New York, NY: Cambridge UP. 1999. p. $84-5$

${ }^{244}$ E. Bradford Burns. A History of Brazil. New York, NY: Columbia UP. 1970. p. 178. Charles Hale has commented that positivism meant different things to different people and that there was "no accepted definition of the term" p. 148. For our purposes, positivism as a sociological ideology can be defined as the belief that in order to progress to higher stages of social evolution, a society needed to formulate policies and laws garnered from positive social 'facts'. In practice, this included extensive educational redesign aimed at producing a new bureaucratic and technical class. See Charles Hale. "Political Ideas and Ideologies in Latin America, 1870-1930". In Ideas and Ideologies in Twentieth Century Latin America, ed. Leslie Bethell. Cambridge, UK: Cambridge UP. 1996. pp. 133-205. For a good account of legal positivism as it applied to the Republican period in Brazil, see Sueann Caulfield. In Defense of Honor: Sexual Morality, Modernity, and Nation in Early-Twentieth Century Brazil. Durham, NC. Duke UP. 2000. esp. pp. $17-47$.

${ }^{245}$ Burns. A History of Brazil, p. 170
} 
Malatesta $^{246}$. This paradox is easily rectified, he continues, if we consider the aspects of Spencer's liberalism that he is less known for: reduction of excessive wealth, and limitations on the strength of the State ${ }^{247}$.

Yet positivism and anarchism share some important common traits, such as that they both value the sensory experiences above abstract idealism or the metaphysical, they both place importance on social evolution and development, and most importantly, they both argue the inherent malleability of society and social norms ${ }^{248}$. Indeed, in 1892 , one of the leading positivist thinkers, Raimundo Teixeira Mendes who was credited with coining Brazil's motto “Ordem e Progresso", wrote a letter to a Rio de Janeiro newspaper defending anarchists against police brutality, later published as a pamphlet ${ }^{249}$. That anarchist thought was to find support - albeit unwilling and indirect - in a nascent Brazilian bourgeoisie and technical class eager to shed what they perceived as the backward tyranny of rural aristocrats, and an aging emperor unable and unwilling to transform Brazilian society expeditiously, helps to explain why the ideas gained quick support in the country. Thus, immigration provides one piece of the puzzle in our attempts to understand the formation of anarchist ideology in Brazil, but it should not be viewed as the sole or primary factor.

\footnotetext{
${ }^{246}$ Peter Kropotkin is clearly interested in Spencer's ideas in Mutual Aid: A Factor of Evolution. New York, NY: Dover. 2006. p. 43. Yet he clarifies his relationship with Spencer early on in the introduction: "there are a number of evolutionists who may not refuse to admit the importance of mutual aid among animals, but who, like Herbert Spencer, will refuse to admit it for Man" p. xvii.

${ }^{247}$ Boris Fausto. Trabalho Urbano e Conflito Social. São Paulo: Difel. 1976. p. 73

${ }^{248}$ Indeed, according to John McVea, Herbert Spencer believed in the "psychological and moral evolution of the individual... [a society that is] inherently ethical...[and] he saw the role of cooperation, and indeed cooperatives, eclipsing competition in importance as society develops to higher levels". "Herbert Spencer Providing Libertarian Foundations?" Business and Society Review. Vol. 106, No. 3. 2001. p. 226

${ }^{249}$ Robert J. Alexander. A History of Organized Labor in Brazil. Westport, CT: Praeger. 2003. p. 9
} 


\section{Transitional Industrialization, Class Relations, and Urban Dislocation}

In the previous chapter, I only briefly mentioned the necessary precondition for the growth of the anarchist movement identified by Robert J. Alexander - the emergence of an urban proletariat to which Leuenroth belonged. When we consider that of all the immigration to São Paulo between 1893 and 1910, an average of only $6.5 \%$ remained in the capital (with $85 \%$ making their way to the western coffee zone), it is obvious that most of the early immigration was predominantly to plantations, where the anarchist movement did not flourish in any significant way ${ }^{250}$. However, disenchanted with the terrible working conditions on plantations, and with increasing demand for workers in the capital, mainly in textile manufactories, many would flock to the urban centers, driving early Brazilian urbanization - and anarchism ${ }^{251}$. By $1920,52 \%$ of the city of São Paulo's industrial labor force was foreign-born ${ }^{252}$.

The roots of Brazilian industrialization are extremely complex, but Warren Dean has attributed it to the dominant coffee industry. Dean has argued that the coffee trade generated demand for industrial goods as well as provided much of the "economic and social overhead necessary to make domestic manufacturing possible"253. Moreover, in a rare case of economic development in Latin America, the rural agricultural class - coffee plantation owners oriented towards the export market - led investment in urban industrial manufacturing, and subsequently the creation of a domestic market, mainly because they

\footnotetext{
${ }^{250}$ Thomas H. Holloway. "Creating the Reserve Army? The Immigration Program of São Paulo, 18861930". International Migration Review. Vol. 12, No. 2. 1978. p. 199. See Cliff Welch. The Seed Was Planted: The São Paulo Roots of Brazil's Rural Labor Movement, 1924-1964. University Park, PA: Pennsylvania UP. 1999. for more on the rural labor movement in general.

${ }^{251}$ São Paulo was at the forefront of this urbanization - in 1890 the city's population stood at only 64,934 , by 1900 , it had reached 239,820 , a growth of more than $350 \%$ ! Richard Graham. Britain and Modernization in Brazil, p. 32

${ }^{252}$ Joseph L. Love. São Paulo in the Brazilian Federation, 1889-1937. p. 83

${ }^{253}$ Warren Dean. The Industrialization of São Paulo, 1880-1945. Austin, TX: University of Texas Press. 1969. p. 8
} 
saw this as an effective strategy to both diversify their holdings, and develop their 'hometowns' in the coffee regions ${ }^{254}$. Such was the case of the Prado family, whose connection to Leuenroth we saw in the last chapter. They diversified into railways and banks and funneled money directed at bringing "European culture and salon life" to the “cultural backwater" of São Paulo ${ }^{255}$.

Other factors were also important, such as a series of monetary policy decisions by the first finance minister of the Old Republic, Rui Barbosa, that were known collectively as the encilhamento. The Ministry doubled the monetary supply by pegging the currency to government bonds instead of gold, and made credit more readily available and easier to obtain, in the hopes that this would induce commercial investment ${ }^{256}$. While it is not clear if this had a direct effect on capital formation expansion in any real way ${ }^{257}$, there were some major changes in the structure of the Brazilian economy during this period. Between 1885 and 1905, the number of cotton textile mills increased ten fold to 110 , most located in and around the city of São Paulo, and employment in textiles increased twelve fold to nearly $40,000^{258}$. Industrial expansion was enormous throughout Brazil during this period: from 1890 to $1914,6,946$ industrial enterprises were begun, most in the form of small factories producing basic consumer goods ${ }^{259}$. One of these was

\footnotetext{
${ }^{254}$ Ibid. p. 34; this is even more remarkable when we consider that agriculturalists received virtually no prodding from the State, nor was the coffee sector reliant on imported machinery. Ibid. pp. 9-11

${ }^{255}$ Linda Lewin. "Review: The Prados of São Paulo". The American Historical Review. Vol. 94, No. 4. 1989. p. 1212

${ }^{256}$ Burns. A History of Brazil, pp. 211-2.

${ }^{257}$ For an account of the controversies surrounding the encilhamento, see Steven Topik. "Brazil's Bourgeois Revolution?" The Americas. Vol. 48, No. 2. 1991. pp. 245-271

${ }^{258}$ Werner Baer. The Brazilian Economy: Growth and Development, $5^{\text {th }}$ ed. Westport, CT: Praeger. 2001. p. 26

${ }^{259}$ Richard Graham. Britain and Modernization in Brazil, 1850-1914. Cambridge, UK: Cambridge UP. 1968. p. 44
} 
the Companhia Industrial de São Paulo, where Leuenroth worked in his first typographic job in 1895 , which was established in $1890^{260}$.

The precursors to industrial growth, infrastructure development (in the form of railroads, power stations, and water companies) and protectionist tariffs were provided by the state in order to serve the coffee boom ${ }^{261}$. Railway construction surged between 1881 and 1900 , with nearly $12,000 \mathrm{~km}$ of new tracks laid, and the state of São Paulo was active in purchasing water companies in the early $1890 \mathrm{~s}^{262}$. The abolition of slavery was central in spurring industrialization as well. Critics at the time, members of the "younger generation" claimed that it inhibited the mechanization of agriculture, capped European immigration to the nation, wastefully used up precious capital, and hindered the growth of a domestic market ${ }^{263}$.

In the city of São Paulo, alongside large factories, were bustling markets for artisan wares, and the products of cottage industries, as well as an emergent professional service sector to cater to them ${ }^{264}$. As we discovered in the last chapter, Leuenroth's newspaper Folha do Brás participated in the development of this nascent capitalism by offering advertising space to local entrepreneurs. In order to regulate and manage the booming growth in the city, as well as because of expanding revenues from the coffee industry, state and municipal bureaucracies developed, with all of the top positions

\footnotetext{
${ }^{260}$ Aldo Musacchio. "Laws vs. Contracts: Legal Origins, Shareholder Protections, and Ownership Concentration in Brazil, 1890-1950". Working Paper No. 08-053. Harvard Business School. Jan. 2008. p. 36

${ }^{261}$ The coffee industry favored cheaper imports, but due to fiscal pressures, tariffs were raised continually after 1857. See Werner Baer. The Brazilian Economy, p. 25, 27

${ }^{262}$ Richard Graham. Britain and Modernization in Brazil, p. 30, 117. Though Brazilian railroads were funded almost entirely by private capital, unique at the time, the empire provided massive subsidies in the form of guaranteed interest on investment (7\%), and the granting of exclusive rights to service for $30 \mathrm{~km}$ on either side of the railroad line. See Benicio Viero Schmidt. "Modernization and Urban Planning in $19^{\text {th }}$ Century Brazil". Current Anthropology. Vol. 23, No. 2. p. 256

${ }^{263} \mathrm{E}$. Bradford Burns. A History of Brazil, p. 196-7.

${ }^{264}$ Boris Fausto. A Concise History of Brazil. Trans. Arthur Brakel. New York, NY: Cambridge UP. 1999. p. 172
} 
available in the capital, further ushering in workers seeking employment prospects resulting from the huge demand for labor ${ }^{265}$.

We can see, then, that these early years of industrialization - the late 1880 s and early 1890s - marked a huge shift and upheaval in the Brazilian social structure and economy. With the abolition of slavery, the establishment of a new political regime, the ascent of positivism, and both the craning glance to happenings in Europe and the beginnings of a strong nationalism, space was opened up for dialogue and discussion on a new social direction for the country that was virtually impossible for people, whether native born, naturalized citizen, or recent immigrant, to ignore. This period of transitional industrialization signified a change in the balance of power shaping the direction that Brazil was to follow until 1930, but because of this, also offered others with ideas of their own space to emerge. By siding with certain economic interests and focusing the bureaucratic apparatus on the needs of some, but not others, the State at its various scales $^{266}$, opened itself up to extended and severe criticism. Thus Eduardo Prado, as discussed in the last chapter, was able to fervently challenge the Republican regime based on his belief that his own monarchical 'Catholic liberalism' was much freer and humane than republicanism, but budding anarchists also found fodder in the power interests that the Republican state aligned themselves with.

These capital interests were predominantly coffee (café), and ranching and dairy (leite). Café com leite, the shorthand that many political economists use to describe the

\footnotetext{
${ }^{265}$ Ibid; Richard Graham. Britain and Modernization in Brazil, p. 32

${ }^{266}$ When discussing the bureaucratic apparatus of the State, I utilize the capital ' $S$ '. When referring to one administrative branch of the federation, in this case, specifically São Paulo, I use the small 's' state.
} 
period $^{267}$, was brewed to serve incipient industrialization, as most of the capital produced from this agricultural sector was funneled into urban manufacturing ventures ${ }^{268}$. Yet the discursive and financial orientation of São Paulo and the federal State still overwhelmingly favored the agricultural oligarchy. As Weinstein noted,

In Brazil...the new political alignments of the late nineteenth century coalesced around an emerging capitalist class which wielded extensive influence, if not absolute control, over the new order. However...the new capitalist class had as its economic base not urban industry but export agriculture... [with] enormous consequences for politics, economics and diplomacy ${ }^{269}$.

Though this balance would change going into the twentieth century, early industrial capitalists found the relative attention devoted to their interests by the political elite wanting ${ }^{270}$. Where they benefited was the lack of attention paid to them, which allowed them ample room to impose hellish working conditions on their employees.

It was the new urban proletariat who got the worst: virtually ignored by elites at all levels of government, except when they were implementing eugenic campaigns or suppressing revolts, and subject to the near tyranny of their employers, they eked out marginal wages only to return to cramped and unsanitary neighborhoods. Thus, Leuenroth's earliest endeavor in social activism, Folha do Brás, lamented the complete inefficacy of the state government to ensure that the basic needs of community members were being met.

Herein lies another explanation for the growth of anarchist thought in early Republican Brazil: confronting harsh working conditions, but in an environment that was

\footnotetext{
${ }^{267}$ Of course, the dynamic of power threading these interests together was much more fluid and contentious, especially after the mid-1910s, as we will see below. See: Steven Topik. The Political Economy of the Brazilian State, 1889-1930. Austin, TX: University of Texas Press. 1987. p. 17

${ }^{268}$ Barbara Weinstein. "Review: Brazilian Regionalism". Latin American Research Review. Vol. 17, No. 2. 1982. p. 266

${ }^{269}$ Ibid. p. 274

${ }^{270}$ This would change with Vargas' self-coup in 1937, which would bring in many industrialists and their intellectuals into policy-making circles. For a detailed account in this reorientation of the State, see Barbara Weinstein. For Social Peace in Brazil: Industrialists and the Remaking of the Working Class in São Paulo, 1920-1964. Chapel Hill, NC: The University of North Carolina Press. 1996.
} 
more conducive to the dissemination of ideas than on the plantation, with little aid from any level of government, produced considerable anger and disillusionment with both the government and capital on the part of the proletariat. Anarchism provided an alternative to this government apathy by encouraging urban citizens that the answers to their problems arising from industrialization rested in their own minds and hands. It was partly this anger and disillusionment, produced through Leuenroth's experiences running up against the 'social question' that stoked him and others to stand up and fight for the rights of their neighbors and fellow humans.

\section{The Old Republican State: Repression, Representation, and the Diffusion of Authority}

Contributing to the disillusionment of what the State was actually doing (or not doing) regarding the harsh realities of urban living in São Paulo was the powerlessness that the political elite tried to force on urban workers by denying them any hope of representation in the formal political process. Indeed, one peculiar and seemingly contradictory effect of the transition from empire to republic was the actual decline of voter participation in elections. While elections in imperial Brazil were never free or fair, especially since they were open and oral, leading to violence and intimidation of the electorate, roughly one million Brazilians out of a population of less than ten million had the right to vote in elections for the national Chamber of Deputies ${ }^{271}$. The 1881 Saraiva Law removed income and property requirements for voter eligibility, and allowed naturalized citizens and ex-slaves to vote, as well as non-Catholics, but imposed a literacy test as a precondition for voting, an alteration to electoral laws that would

\footnotetext{
${ }^{271}$ The secret ballot was not instituted until 1932 in Brazil. Leslie Bethell. "From Elections without Democracy to Democracy without Citizenship". In Brazil Since 1985: Economy, Polity, and Society. Eds. Maria D'Alva Kinzo \& James Dunkerley. London, UK: Institute of Latin American Studies/University of London. 2003. pp. 24-6.
} 
become embedded in the 1891 Republican constitution and remain until $1985^{272}$.

Nationally, illiteracy rates were as high as $75 \%$ of the population into the 1920 s, and in 1890 in the city of São Paulo with its large number of professionals and intellectuals, only $35.2 \%$ of males were literate ${ }^{273}$.

Not only were formal avenues of politics closed to most urban residents, but their contact with state representatives was often disheartening - or worse, bloody - if they sought to protest by other means. Such was the case, mentioned briefly in Chapter 2, when workers of the Companhia Paulista de Estradas de Ferro went on strike following May Day celebrations in 1906 resulting in a number of deaths. The police arm of the state government, the Força Pública, did not hold back in crushing what they perceived, in the words of the São Paulo city police chief, was the work of "anarchists, agitators by trade, who are paid by foreign governments to kill our industry"274. During the 1917 General Strike, Everardo Dias distributed a pamphlet with a direct appeal to the soldiers signed by a number of female strikers that stated "TO THE SOLDIERS! You should not persecute your brethren in misery. You too belong to the great popular mass...Soldiers! Refuse to be executioners!"275 Urban residents beset by apathy from the political and economic elite who dared resist their squalid conditions and unfair treatment risked violent repression if their protests stepped on the toes of the republican beast of "progress ${ }^{276}$.

\footnotetext{
${ }^{272}$ Of course, with the Saraiva Law, women were still barred from formal political participation. They would not get the vote until 1932 .

${ }^{273}$ June E. Hahner. Poverty and Politics: The Urban Poor in Brazil, 1870-1920. Albuquerque, NM: University of New Mexico Press. 1986. p. 90

${ }^{274}$ Qtd. in Dulles. Anarchists and Communists in Brazil, pp. 21-2

${ }^{275}$ Qtd. in Ibid. p. 47

${ }^{276}$ Repression would intensify in the $1920 \mathrm{~s}$. When anarchists courted the officers of the tenentes rebellion (whose leader would become the leader of the Communist party in the 1940s) in São Paulo in July of 1924, federal troops bombarded the working class neighborhoods where the rebels were holding out with artillery and aircraft, resulting in the death of nearly 1,000 residents and the injury of a further 4,000. See Joel Wolfe. Working Women, Working Men, pp. 35-9
} 
Direct action would undoubtedly seem an attractive alternative to the formal political process that excluded the majority of the working class. For the few who could participate, the knowledge and experience of the fact that their minority numbers ensured that their voices remained silent would also make anarchist and anarcho-syndicalist methods promising. Even with the guarantee that the State would retaliate, workers participated in 109 strikes in the city between 1917 and 1920, including two general strikes (the largest involving around 50,000 strikers). These strikes often led company owners to grant partial concessions to the workers ${ }^{277}$. It is probable that had the State taken a more conciliatory approach to industrial and labor relations than it did throughout the Republican period, anarchists would not have had garnered the strength that they had, especially in the second half of the 1910s. Though it is most likely coincidental, the first federal welfare legislation for workers was enacted only in 1919, including a workmen's compensation plan for accidental injury and death, the year that marks the pinnacle (and thus the beginning of the decline) of anarchist activity in São Paulo ${ }^{278}$.

As discussed in Chapter 2, it was widely understood by anarchist leaders such as Leuenroth that their impact on the labor movement was generally marginal. Both anarchism and anarcho-syndicalism, as specific ideologies requiring considerable commitment, found their strongest advocates in a small minority, although given the wide readership and popularity of many of the publications, it is likely that public sympathies, if not ideological commitment, towards them were quite strong. While many of the greatest anarchist activists were from the working class, others who were not necessarily disenfranchised under the Old Republic flocked to the anarchist banner. Eric Gordon has

\footnotetext{
${ }^{277}$ Boris Fausto. Trabalho Urbano e Conflito Social. São Paulo: Difel. 1976. p. 162, 253

${ }^{278}$ Joseph L. Love. São Paulo in the Brazilian Federation, p. 89
} 
pointed out this tendency, noting "for some Brazilians who had struggled for an enlightened form of government [Republicanism], and who had shortly seen it prostituted to the same coronéis and overlords as before, anarchism was an easy next step in their thinking"279.

Some elites, such as Leuenroth's friend José Oiticica, who was the well-educated son of a senator and a property owner in Alagoas, felt the orientation of the Republic to be problematic. Working as a school director in Santa Catarina, he began thinking about State and society in Brazil and, without reading any anarchist literature, found that his line of thinking matched theirs. Joining the movement, he would maintain a lifelong commitment to anarchism. Regardless of the rationale, whether it be the Republic's utter disregard for the majority of its constituents, the perceived hypocrisy of the regime when comparing it with its predecessor, the belief that it was aligning itself with the wrong interests, or that it was taking Brazil in the wrong direction on the track of social evolution, the political and economic focus of the Republican State aided the growth of anarchist thinking in Brazil.

One of the political aspects of this growth was contained in the structure of the Republican State itself. In contrast with the centralized political control of both the Empire and the Vargas regime of 1930-1945 when anarchist ideas were relatively dormant, the Old Republican era was initially marked by a system of dual federalism with extensive state autonomy, though this quickly shifted to de facto centralization driven by the interests of a few leading states (café com leite) ${ }^{280}$. But this control over political and economic affairs was not willingly given by the national state. Perissinotto

\footnotetext{
${ }^{279}$ Eric Arthur Gordon. "Anarchism in Brazil: Theory and Practice", p. 22

${ }^{280}$ Wayne A. Selcher. "A New Start Toward a More Decentralized Federalism in Brazil?" Publius. Vol. 19, No. 3. 1989. p. 168
} 
has demonstrated that in fact the entire period of the first Republic was marked by a constant power struggle over the reigns of the State apparatus by state elites and highlevel national officials ${ }^{281}$. Thus Mario Pinto Serva, an ardent São Paulo advocate and dedicated Republican, published a lengthy article in the state's leading newspaper in 1917 praising the overwhelming economic contribution of São Paulo in contrast with all other Brazilian states, and documenting the increasingly uneven distribution of export revenues between the state and the federal government. Drawing upon the cultural tropes of the bandeirantes, the article never explicitly calls for independence, but instead argues for a new form of political organization that takes advantage of paulista 'political energies in the same way that the country takes advantage of their economic energy ${ }^{282}$.

There are a number of consequences resulting from a decentralized federalism in a country dominated so heavily by an elite class producing a monoculture crop. On one hand, without a strong state to direct growth and manage political contentions from diverse quarters of society, the blatant disregard for or impotence of the State towards those not benefiting from the economic system produced cynicism at the very least, and outright dissent in many cases. On the other, if the federal State was going to be more than just the vassal of a specific capitalist class, as was the state government, it not only faced contention from the masses, but from those same capitalists it had initially aligned itself with. In crude terms, the outcome of the decentralization of political and economic authority under the structural terms of $19^{\text {th }}$ century Brazil was like the unleashing of a capitalist beast which, once tasting the possibility of the power it could wield, would

\footnotetext{
${ }^{281}$ See Renato Monseff Perissinotto. "State and Coffee Capital in São Paulo's Export Economy (Brazil 1889-1930)". Journal of Latin American Studies. Vol. 35, No. 1. pp. 1-23

${ }^{282}$ Mario Pinto Serva. "A energia paulista". O Estado de São Paulo. 9 Jul. 1917. p. 4
} 
engage in an 'arms race' with the State. The outcome of this self-defeating process was the ultimate end of the regime in 1930 after a decade of extremely tenuous control.

Yet the battle of the São Paulo state elites against the federal State was at least indirectly conducive to the growth of the anarchist movement. Anarchists could find criticisms of the federal government along broadly libertarian lines in the press organs of the state bourgeois class, for example $O$ Estado de São Paulo, though of course, they rarely joined them in much else than criticism. Many of the arguments that paulistas made to bolster their political power focused on the global economic necessities of orienting the economy around the competitiveness of coffee exports. Similarly, Gordon highlights the supranational character of Brazilian anarchism: its celebrations decried world proletarian history, and it identified with global struggles for freedom and equality, particularly in Russia for the first two decades of the twentieth century ${ }^{283}$. Thus, the stratification and refraction of political authority in Old Republican Brazil, as laid out in the 1891 constitution, coupled with the economic and social realities of monoculture, development, and immigration - though hardly sufficient - were certainly a contributing factor to the quick growth in anarchist ideology.

\section{Brazilian National Identity(ies): Contesting Cultural Space}

Though the topic has generally received immense attention by academics in the last decade, the formation of national identity in Old Republican Brazil is not understood very well in its relation to anarchism. It is obvious that anarchists were not involved in advancing a nationalism that bolstered the central State or the political authority of subnational elites, but it is too easy to say that they eschewed nationalism entirely, or that their activities did not contribute to Brazilian culture on various geographic and political

${ }^{283}$ Eric Arthur Gordon. Anarchism in Brazil: Theory and Practice, p. 21 
scales. Thus, it is important to examine how the structure of central State-directed nationalism facilitated the growth of anarchism, but also how anarchists contributed to a redefinition of Brazilian culture.

In the 1930s, with radio as an emergent mass communication media that did not require literacy, an expanding cinema industry, and a massive centrally directed nationalist education campaign, the Vargas regime sought to reclaim Brazilian historicalcultural figures for use in advancing a vision of the State ${ }^{284}$. In contrast, with reference to the Republican period, Jeffrey Lesser has argued that:

From the mid-nineteenth century on, both ['Brazilian' and 'Brazilian-ness'] were increasingly arbitrary [terms], creating the space needed by newcomers to insert themselves into, or to change, paradigms about national identity. A single or static national identity never existed: the very fluidity of the concept made it open to pushes and pulls from below and above ${ }^{285}$.

Indeed, while it is true that national identities are always fluid to varying degrees, the Old Republican national State found it especially difficult to control cultural discourse to serve its purpose, aided partly by the political structure described above, the cultural orientation of elites towards Europe at the time, and the influx of immigration.

Thus, when Serva invoked the bandeirante, and the long history of selfdetermination by paulistas in his 1917 article, he did so in order to draw a contrast against the poorly defined and vacuous national identity and national State whose policies he was criticizing ${ }^{286}$. He sought, on behalf of the his state's bourgeoisie, to advance a political agenda that framed national discourse in such a way that the states, São Paulo above all, were the most prominent administrative and cultural unit in the Brazilian

\footnotetext{
${ }^{284}$ On these cultural aspects of the Vargas regime, see Bryan McCann. Hello, Hello Brazil: Popular Music in the Making of Modern Brazil. Durham, NC: Duke UP. 2004; Anita Simis. "Movies and Moviemakers Under Vargas". Latin American Perspectives. Vol. 29, No. 1. 2002. pp. 106-114; Carmen Nava "Lessons in Patriotism and Good Citizenship: National Identity and Nationalism in Public Schools During the Vargas Administration, 1937-1945”. Luso-Brazilian Review. Vol. 35, No. 1. 1998. pp. 39-63.

${ }^{285}$ Jeffrey Lesser. Negotiating National Identity, p. 3

${ }^{286}$ Mario Pinto Serva. "A energia paulista". O Estado de São Paulo. 9 Jul. 1917. p. 4
} 
federation. This would be quite similar to the anarchist discursive strategy, based on their ideological beliefs, which would extend Serva's argument further to argue that individuals formed the true core of the Brazilian nation, and consequently political organization and the distribution of authority should reflect this.

Cultural tropes played an important role in this battle over national identity. While the bourgeois elite used the half-mythical characterization of the bandeirante to justify their expansion of the coffee industry and their place at the helm of Brazilian economy and society, others could take what they wanted out of this character. Joseph Love has pointed out that

For half a century, few literate Paulistas had doubted that their collective psychology had been inherited from the bandeirantes, but most writers and speakers emphasized their positive aspects: the bandeirante had pushed back the frontier; he had applied his energies to productive ends; he had perceived and seized his opportunities; and he had pointed the way to the future for the Brazilian nation $^{287}$.

Though it is certainly true that given the persistence of this cultural trope throughout paulista social institutions it would be difficult for most Brazilian-born and naturalized citizens to ignore, many educated anarchists knew enough about state history to be critical of the bandeirante's marauding spirit and enslaving past. Instead, they found their semi-mythic figures in the cultural memory of the quilombos, maroon communities built by runaway slaves who refused enslavement. José Oiticica, for example, likened the selfdetermination of Zumbi, the founder of Palmares, the largest and best-known quilombo, to anarchist direct action alongside Spartacus, and medieval serfs ${ }^{288}$.

Just as the bourgeoisie were intent on constructing a history and a nationalist culture that served their own interests, anarchists looked to a national history to justify

\footnotetext{
${ }^{287}$ Joseph L. Love. São Paulo in the Brazilian Federation, p. 69

${ }^{288}$ José Oiticica. "Método de Ação". In Anarquismo: Roteiro da Libertação Social. Ed. Edgard Leuenroth. Rio de Janeiro: Editora Mundo Livre. 1963. p. 48
} 
and situate their contemporary struggles, even if the main purpose was rhetorical in that these tropes served to relate anarchist principles to a majority of people not acquainted with them. In the absence of a strong national identity imposed through the central State apparatus, social actors in Old Republican Brazil faced fewer constraints in developing a cultural identity to support their political identities. In consequence, they were able to advance a cultural discourse that aligned more closely with their political intentions.

The huge increase in the percentage of the foreign-born population between the mid-1880s and the 1920s certainly impacted the development of a Brazilian national identity. In 1893, nearly 55\% of São Paulo's population was foreign born ${ }^{289}$. Eric Gordon has claimed that most of the immigrants who arrived in Brazil were "demonstrably disinterested in acquiring Brazilian citizenship", though it is more likely that they sought to remake Brazilian citizenship into something that they could find meaning in ${ }^{290}$. Just as socialites sought to emulate all of the Parisian fashions, and remake society in accordance with the teleology of European development discourse, the working classes, both immigrant and native-born, established budding local print cultures, participated in theatre groups, sang and wrote poetry, and gathered in their neighborhoods to discuss current events ${ }^{291}$.

Far from entirely rejecting 'Brazilian' identity, many anarchists sought to remake what Brazilian-ness meant, to impute their ideological values into that aspect of collective identity. Everardo Dias reminisced about an ultra-anti-nationalist "globe-

\footnotetext{
${ }^{289}$ June E. Hahner. Poverty and Politics: The Urban Poor in Brazil, 1870-1920. Albuquerque, NM: University of New Mexico Press. 1986. p. 47

${ }^{290}$ Eric Arthur Gordon. "Anarchism in Brazil: Theory and Practice", p. 21

${ }^{291}$ See Edgar Rodrigues. Os Anarquistas: Trabalhadores Italianos no Brasil. São Paulo: Global Editora. 1984. pp. 134-53; Fernando Peixoto, Susana Epstein and Richard Schechner. "Brazilian Theatre and National Identity". TDR. Vol. 34, No. 1. 1990. pp. 60-69
} 
trotter" anarchist that was well seasoned in various languages and cultures who

constantly attacked everything Brazilian with "insufferable disdain":

The soul of the nation, the spirit of the land, the created environment, the nature of its formation, all of this went unobserved by him, as an inaccessible secret, an impenetrable forest. He had a fundamental incapacity influencing his spirit, his vision, in his feelings, fruits, perhaps, of impressions received in other countries, of pejorative commentaries on the country and its people $^{292}$.

'Brazil' meant something to those that were born and grew up there, and to many who arrived even late in life. As a consequence of this unnamed globe-trotter, many who would have contributed to the anarchist cause, left it with "undisguised hostility" ${ }^{\text {"293. }}$

Thus, early anarchists could find space to advance their own beliefs on what it meant to be Brazilian (or Italian-Brazilian) in the relatively contested cultural and nationalist discourses of the Old Republic. In the absence of a standardized nationalism that served State interests, anarchists sought to redefine national identity by drawing from historical figures that fought for freedom and equality, in an effort to shift the bounds of citizenship to those that agreed with their political interests, which would boost its public profile leading to the attraction of more adherents.

Yet, this would not last long. Just as Vargas would appropriate Samba from AfroBrazilians in Rio de Janeiro to use as a symbol of national identity when he came to power in the 1930s, he would also redefine the role of the state in relation to workers by drawing upon the cultural history of the tenente rebellion, crafting himself as the 'father of the poor ${ }^{294}$. Along with his severe repression of those who refused to conform to his

\footnotetext{
${ }^{292}$ Everardo Dias. História das Lutas Sociais no Brasil. São Paulo: Editora Alfa-Omega. 1977. pp. 209-10

${ }^{293}$ Ibid. p. 210

${ }^{294}$ See Robert M. Levine. Father of the Poor? Vargas and his Era. Cambridge, UK: Cambridge UP. 1998.
} 
new system of industrial relations, this would result in the displacement of anarchists as a real force in public discourse that they still have not regained ${ }^{295}$.

\section{Conclusion: Connecting Structure to Agents}

Like all intellectual currents in history, the growth of anarchism in Brazil is enigmatic and hard to pin down. Many factors contributed to its rise at the specific moment in which it did, as well as in the specific context that it did. To reiterate, I have argued that while immigration undoubtedly played a role in bringing anarchist ideals to Brazil and encouraging their spread, mainly by collecting so many radicals in geographically confined places who subsequently disseminated classic anarchist texts to native-born Brazilians, other 'homegrown' factors played important roles as well. Prior to the establishment of the First Republic, it was dissatisfaction with the slow progress of the empire and the rise of positivism as an ideology centered on social progress that coincided with the emergence of anarchist texts and contributed to making their values accessible to Brazilians.

Connected to this was the 'modernization' of the economy - the abolition of slavery and agriculture-led investment in urban manufacturing ventures and with it the rise of an urban proletariat. Without this new class formation, anarchist ideals, namely in their anarco-syndicalist form, would not likely have resonated with a diffuse agricultural labor force on the scale necessary to turn localized niches into movements. The tenuous alliance of State and capital (namely coffee and dairy) coupled with horrid working conditions in industrial factories, but the ability for workers to communicate their ideas cramped together in dense urban neighborhoods produced disillusionment and anger on

${ }^{295}$ See Robert J. Alexander. A History of Organized Labor in Brazil, pp. 57-9 
the part of the working class that explains why many anarchists such as Leuenroth identified with anarchism.

It was also the character of the Brazilian State, eager to repress any dissent that challenged 'order and progress' and punitive electoral laws that ensured the majority of Brazilian workers could not participate in the formal political process that contributed to resonance of the anarchist method of direct action. Others, some of them elites, who saw their vision of republicanism as the pathway to progressive social change destroyed by the continuance of oligarchic rule would also find solace in anarchism. Furthermore, the decentralized federalism of the Old Republican State provided discursive space to contest the balance of decision-making authority, space that many anarchists seized upon.

Finally, the lack of a strong centralized national identity controlled by either the national State or sub-national elites, and with it an apparatus of cultural institutions designed to bolster it, meant that more room opened up to debate just what it meant to be Brazilian. Anarchists engaged in this debate both textually and through their participation in a number of cultural practices that helped root their political values in the shared experiences of working people.

Given all of this, we still have a relatively cloudy understanding of anarchism in São Paulo, and in Brazil more generally. In order to get a better understanding of this ideology, desperately needed to bolster the gaps of the recent literature on Brazilian social history, we need to look at the micro-histories of hundreds of biographies, work to link them to each other, and then connect these agent-centered linkages to the structural history that is better represented in the literature. I have tried to begin to do this last part with my discussion in this chapter, though there is ample room for debate on the reasons 
for why so many people became interested in anarchism from the 1890 s to the 1920 s and why even more people did not. I have chosen these factors to look at, partly to dialogue with Bradford Burns' somewhat vague insight, "Urbanization, modernization, industrialization, and nationalism mutually interact, and their combined strength accelerates the rate of [historical] change" 296 . Structurally, the time period in which anarchism arose in São Paulo, and throughout Brazil, was certainly tumultuous, and this alone is a good starting point for developing a much deeper history of Brazilian anarchism.

${ }^{296}$ E. Bradford Burns. A History of Brazil, p. 5 


\section{Conclusion: Between New and Old: Arguments and Scholarship}

Before I conclude with a summary of this thesis, let me offer by way of a postscript, an introduction to an issue within studies of anarchism that has received far too little attention thus far. Most historians or social scientists find it extremely difficult to discuss events in Old Republican Brazil in detail without reference to 'race'. The end of racialized slavery basically coincided with the rise of the Republic, and yet racist practices and policies continued unabated, or even intensified ${ }^{297}$. One would assume that this important aspect of Old Republican social life has established itself in every facet of Brazilian historiography, yet this is not the case. Very little is mentioned by scholars working on the anarchist movement that addresses the question of how 'race' figured into the dynamics of the anarchist and labor movements. What I have come across are mostly tangential points of contention that I can only hope to outline here. Thus, I raise these points as a way of shining the spotlight on an avenue for future scholarship.

\section{Anarchism and 'Race': New Avenues for Scholarship}

Leuenroth's tenure at $O$ Comércio put him into contact with many notables in the Brazilian intellectual community. He himself was aware of this, pointing out a few of them by name and calling the office a "treasure trove of intellectuals"298. Two of these names stand out for their impact on Brazilian society: Eduardo Prado and Afonso Arinas. Behind the velour of the compassionate Catholic monarchist, Eduardo Prado was a notable anti-Semite. Levi reveals that on his fazenda, Eduardo had poked holes through

\footnotetext{
${ }^{297}$ The literature is enormous, but see for example, Thomas E. Skidmore. Black Into White: Race and Nationality in Brazilian Thought. Durham, NC: Duke UP. 1993; Todd A. Diacon. Stringing Together a Nation. Cândido Mariano da Silva Rondon and the Construction of a Modern Brazil, 1906-1930. Durham, NC: Duke UP. 2004; and Jeffrey Lesser. Negotiating National Identity: Immigrants, Minorities, and the Struggle for Ethnicity in Brazil. Durham, NC: Duke UP. 1999.

${ }^{298}$ Dealbar, p. 1
} 
the eyes of all of the Jewish parliamentarians on a poster of all of the members of the British House of Lords, and spoke with virulence about Jewish people ${ }^{299}$. Yet Prado also praised miscegenation among the "three races" in the construction of Brazil as a redeeming factor of its nationalism ${ }^{300}$, and he was never a slave-master unlike his family members. Thus, it would appear his attitude towards 'race' was somewhat ambiguous, though as Mark Hillary Hansen points out, he was quite content with "slow progress"301. Afonso Arinos was the uncle of Afonso Arinos de Mello Franco, a man with strong opinions on 'race'. In a 1936 book entitled The Conceit of Brazilian Civilization, the nephew declared that the Indian "contributed only improvidence and dissipation" to the Brazilian character, while "the Negro" gave it its "preoccupation with sexuality, occultism, and obsession with cabalistic numerology" ${ }^{\text {302 }}$. He would later go on to provide the name for a 1950s law that despite claiming to make racism a crime, would have the effect of sidestepping claims of structural racism in Brazil and strengthening the myth of racial democracy ${ }^{303}$.

Leuenroth's relationships with these two figures say little about his own attitudes on the issue of 'race'. However, what is most striking is that these attitudes are curiously absent in any kind of conscious way in all of his ideological or autobiographical writing. Racial or phenotypic stereotypes did play a major role in the anarchist press, as witnessed by the posters that depict both workers and capitalists with overwhelmingly caucasian

\footnotetext{
${ }^{299}$ Levi. The Prados of São Paulo, p. 119

${ }^{300}$ Nearly two generations before Gilberto Freyre would make his career on this claim, as both Levi and Hillary Hansen point out.

${ }^{301}$ Ibid. p. 120; Mark Hillary Hansen. Eduardo Prado, Liberal Monarchist and Catholic Nationalist: A Whig Rebel in Brazil's Old Republic. PhD Diss. Columbia University. 2002. p. 34

${ }^{302}$ Robert M. Levine. The Vargas Regime: The Critical Years, 1934-1938. New York, NY: Columbia UP. 1970. p. 22

${ }^{303}$ See Sérgio Salomão Shecaira. "Racism in Brazil: A Historical Perspective" Revue Internationale de Droit Pénal. Vol. 73. 2002. pp. 141-153
} 
phenotypical traits, including those published by $A$ Plebe $e^{304}$. Anarchist philosophy, as elaborated by Leuenroth himself, would claim that "the anarchist...does not recognize differences of race or nationality", yet their representations of the totality of humanity, as well as the composition of their loudest adherents would be curiously homogenous ${ }^{305}$. Moreover, Leuenroth was overtly aware of the regional dynamics within his own country, highlighting the Bahian region on a number of occasions - which was, and continues to be well known in Brazil for their different racial demographics ${ }^{306}$.

Though I cannot make a firm argument on the way 'race' was thought of - or portrayed - by Leuenroth throughout his long life, or even the role that anarchists in Brazil played in perpetuating or challenging racial stereotypes here, there is clearly a tension or contradiction that needs to be pried open in order to get at the underlying power structure of the Old Republican period. Though it is relatively clear that few anarchists, at least not the São Paulo anarchists I am familiar with, were engaged in debates over the merits of eugenics with the same vigor as their Argentine counterparts, it is certainly less clear how they viewed 'race' fitting into the social dynamic ${ }^{307}$. We would certainly benefit from knowing to what extent racist ideas pervaded both into the theory of anarchism, and into the practices of anarchists as they went about their daily lives, though it is clear that in Brazil the former was not the case. Not only would we learn more about the persistence of racist scientific and cultural ideologies creeping into the

\footnotetext{
${ }^{304}$ Dulles brings together a number of these in Anarchists and Communists in Brazil. For a few exemplary line drawings, see pages 137, 214, 224, 322, 324, and 327.

${ }^{305}$ Edgard Leuenroth. Anarquismo: Roteiro da Libertação Social. Rio de Janeiro: Editôra Mundo Livre. 1963. p. 27-8.

${ }^{306}$ For a more detailed discussion on the importance of Brazilian regionalism at the time, see Joseph L. Love's São Paulo in the Brazilian Federation, 1889-1937. Stanford, CA: Stanford UP. 1980. pp. xvi-xx; 267-274

${ }^{307}$ See Eduardo A. Zimmermann. "Racial Ideas and Social Reform: Argentina, 1890-1916". The Hispanic American Historical Review. Vol. 72, No. 1. 1992. p. 42
} 
production of individual identity, but also about the size of the gulf between theory and practice for Old Republican anarchists.

\section{Three Arguments on Three Levels}

Throughout this thesis, I have tried to form arguments on a number of different levels. Let me summarize those arguments once again. First, I have made the methodological argument that insists that we need to rethink the way we both view biographies as a legitimate scholarly activity, and the way in which we go about conducting our biographies. Biography can tell us a lot more about our world than simply how an individual fits into it - if it is appropriately conceived and scoped. I have suggested a schematic of the key factors that go into the production of ideological identity, including the under-explored factors of ecological relationships and the social psychological alongside more common factors such as historical context, and interpersonal connections. This, along with rethinking about how we orient and organize our biographies can help us get at new social and historical insights.

Second, I have made the argument that the fact that there is so little work done on anarchist biographies, and on the anarchist movement in Brazil in general ensures that our understanding of that aspect of the Brazilian social experience will continue to have significant gaps. In particular I have argued that given Edgard Leuenroth's contribution to the movement, evidenced in his role in the 1917 São Paulo general strike, and his subsequent role in opening up so many new avenues for social research in Brazil with his archival contribution, we should know more about this interesting character. However, it is not only for this reason that his biography is needed: I have also argued that looking into Leuenroth's life can tell us more about Brazilian anarchism, its appeal at the time, its 
relation to the labor movement, and also why certain individuals flocked to it. To demonstrate this argument, I have sought to take the first steps in bringing the life and thought of Edgard Leuenroth to the attention of English-speaking readers by way of my partial biography. My intention was to connect Leuenroth's ideological formation to both the broader theories of anarchism as in Chapter 1, as well as to the wider structural shifts that Brazil experienced between the 1880 s and the 1920 s as in Chapter 3. Thus, it was my intention to demonstrate how the individual biography can serve as a bridging point between both prevalent and unique ideas and the general trends of the times in which that individual lived. The outcome, and I hope the reader shares this assertion, is a layered though not broader, a textured though not more detailed account of anarchist thought and activity in Old Republican Brazil than traditional biographies have offered thus far.

Finally, throughout this thesis I have made more subtle arguments in relation to the claims contained in the secondary literature. For example, in Chapter 1, I produced what I think is a more nuanced and broadly applicable definition of anarchism than the traditional 'rejection of State and authority" that is used by most anarchist writers. In Chapter 2, I highlighted the tensions and contradictions regarding certain facts of Leuenroth's life by some authors, for example, around the initial publication date of $A$ Plebe, hoping that a lengthy process of dialectic argumentation can occur that will give us a better understanding of Leuenroth's life. In Chapter 3, I challenged some of the assumptions and assertions of writers regarding the origins of Brazilian anarchism, especially the thesis that explains its development almost entirely through immigration.

This thesis, like all works of scholarship, is an incomplete work in progress. It is far from perfection, and amenable to dispute. Indeed, this is the broadest of all the 
arguments, thoroughly embedded in a belief in critical scholarship, that I make. No academic text is above contestation, and none is the 'truth' in the final sense of the word. This would seem to be a moot point in academia, where critical scholarship is, or should be, the norm. Yet as noted at the outset, we still have not extended our knowledge of anarchism in Brazil apace with our knowledge of other ideologies, of other facets of the social experience. Especially in the realm of biography, this is a lesson that could still be put into practice. I hope in the near future that it will. 


\section{Works Cited}

Alexander, Robert J. A History of Organized Labor in Brazil. Westport, CT: Praeger. 2003.

Anderson, Benedict. Imagined Communities. New York, NY: Verso. 1991.

“A Revolução Russa: Um autographo - Pedro Kropotkine". O Comércio de São Paulo. 6 May 1906. p. 4

Auyero, Javier. Contentious Lives: Two Argentine Women, Two Protests, and the Quest for Recognition. Durham, NC: Duke UP. 2003.

Avrich, Paul. Anarchist Portraits. Princton, NJ: Princeton UP. 1988.

“A Voz dos Operários". Fenae Agora. Ano. 5, vol. 2, Edição 30. 2002.

Baer, Werner. The Brazilian Economy: Growth and Development, $5^{\text {th }}$ ed. Westport, CT: Praeger. 2001.

Baily, Samuel L. "The Italians and the Development of Organized Labor in Argentina, Brazil and the United States, 1880-1914". Journal of Social History. Vol. 3, No. 2. 196970. pp. 123-34

Bakunin, Michael. God and the State. New York, NY: Dover. 1970.

Barman, Roderick. Brazil: The Forging of a Nation, 1798-1852. Stanford, CA: Stanford UP. 1988.

Berkman, Alexander. The ABC's of Anarchism. New York, NY: Dover. 1972.

Bertucci, Liane Maria, "Cidade, Saude e Militância Operária. São Paulo, Início do Século XX". Conference Proceeding, 49 Congreso Internacional del Americanistas (ICA). Quito, Equador. 7-11 Jul, 1997. Available at http://www.arqueologia.com.ar/congresos/contenido/49CAI/Bertucci.htm

Bethell, Leslie. "From Elections without Democracy to Democracy without Citizenship". In Brazil Since 1985: Economy, Polity, and Society. Eds. Maria D'Alva Kinzo \& James Dunkerley. London, UK: Institute of Latin American Studies/University of London. 2003. pp. 21-41

Biondi, Luigi. "Desenraizados e integrados: Classe, etnicidade e nação na atuação dos socialistas italianos em São Paulo (1890-1930)". Nuevo Mundo Mundos Nuevos. 12 March 2007. 
Birardi, Angela and Gláucia Rodrigues Castelani "Gráficos: os artesãos das palavras" Klepsidra. Ano III, Num. 13. Outubro-Novembro 2002.

Blumer, Herbert. Symbolic Interactionism: Perspective and Method. Berkely, CA: University of California Press. 1969.

"Boletim Eleitoral", A Provincia de São Paulo. Nov. 1st 1881.

Bookchin, Murray. The Spanish Anarchists: The Heroic Years, 1868-1936. Oakland, CA: AK Press. 1998.

Burns, E. Bradford. A History of Brazil. New York, NY: Columbia UP. 1970.

Caulfield, Sueann. In Defense of Honor: Sexual Morality, Modernity, and Nation in Early-Twentieth Century Brazil. Durham, NC. Duke UP. 2000.

Chilcote, Ronald "Book Review of Anarchists and Communists in Brazil, 1900-1935". American Political Science Review. Vol. 71, No. 1. 1977. pp. 376-7.

Craib, Ian. Experiencing Identity. London, UK: Sage. 1998.

Crow, Graham. Social Solidarities: Theories, Identities and Social Change. Philadelphia, PA: Open University Press. 2001.

Dean, Warren. The Industrialization of São Paulo, 1880-1945. Austin, TX: University of Texas Press. 1969.

Deleuze, Gilles and Felix Guattari. A Thousand Plateaus: Capitalism and Schizophrenia. Trans. Brian Massumi. Minneapolis, MN: University of Minnesota Press. 1987.

Diacon, Todd A. Stringing Together a Nation. Cândido Mariano da Silva Rondon and the Construction of a Modern Brazil, 1906-1930. Durham, NC: Duke UP. 2004.

Dias, Everardo. História das Lutas Sociais no Brasil. São Paulo: Editora Alfa-Omega. 1977.

Dulles, John W. F. Anarchists and Communists in Brazil. Austin, TX: University of Texas Press. 1973.

"Edgard Leuenroth and the 1917 Strike". In Against All Tyranny! Essays on Anarchism in Brazil. Ed. Paul Sharkey. Berkeley, CA: Kate Sharpley Library. 2003. pp. 21-3.

"Escola Modelo do Carmo". Centro do Referência em Educação Mario Covas. Governo do Estado de São Paulo. http://www.crmariocovas.sp.gov.br/pdf/neh/1825-

1896/1890_Escola_Modelo_do_Carmo.pdf 
Fausto, Boris. A Concise History of Brazil. Trans. Arthur Brakel. New York, NY:

Cambridge UP. 1999.

----------. Trabalho Urbano e Conflito Social. São Paulo: Difel. 1976.

Felici, Isabelle. Les Italiens dans le mouvement anarchiste au Brésil, 1890-1920. Thèse de Doctorat: Université de la Sorbonne. 1994.

French, John D. “The Latin American Labor Studies Boom”. International Review of Social History 45. 2000.

French, John D. "Practice and Ideology: A Cautionary Note on the Historian's Craft". The Hispanic American Historical Review. Vol. 71, No. 4. 1991.

Fromm, Erich. Escape from Freedom. New York, NY: Henry Holt \& Company. 1994.

Galvin, Michael. "Power, Subjectivity, Resistance: Three Works on Postmodern Anarchism". New Formulation. Vol 2, No. 2. 2004.

Geertz, Clifford. The Interpretation of Cultures. New York, NY: BasicBooks, 1973.

Glendenning, Victoria. "Lies and Silences". In The Troubled Face of Biography. Eds. Eric Homberger and John Charmley. London, UK: The Macmillan Press. 1988. pp. 49-62

Gonçalves, Aracely Mehl and Maria Isabel Moura Nascimento "Jornal E Educação: A Formação Do Militante Anarquista". Paper presented at the $16^{\text {th }}$ Congresso de Leitura do Brasil. July $10^{\text {th }}-13^{\text {th }}, 2007$. Campinas, SP).

. “A Educaçã Libertária e a Imprensa Anarquista (1917-1927)”.Paper delivered at IV Congresso Brasileiro de História da Educação. Goiâna, GO. November 5th -8 th, 2006.

Gordon, Eric Arthur. "Anarchism in Brazil: Theory and Practice". Ph.D dissertation. Tulane University. 1978.

Graham, Richard. Britain and Modernization in Brazil, 1850-1914. Cambridge, UK: Cambridge UP. 1968.

Graham, Robert. Anarchism: A Documentary History of Libertarian Ideas. Montreal, PQ: Black Rose Books. 2005

Guérin, Daniel. No Gods, No Masters: An Anthology of Anarchism. Oakland, CA: AK Press. 2005.

Guevara, Ernesto 'Che'. The Motorcycle Diaries: Notes on a Latin American Journey. New York, NY: Ocean Press. 2003. 
Habermas, Jürgen. On the Pragmatics of Social Interaction: Preliminary Studies in the Theory of Communicative Action. Trans. Barbara Fultner. Cambridge, MA: The MIT Press. 2001.

Hahner, June E. Poverty and Politics: The Urban Poor in Brazil, 1870-1920. Albuquerque, NM: University of New Mexico Press. 1986.

Hale, Charles. "Political Ideas and Ideologies in Latin America, 1870-1930". In Ideas and Ideologies in Twentieth Century Latin America, ed. Leslie Bethell. Cambridge, UK: Cambridge UP. 1996. pp. 133-205.

Hall, Michael M. “The Origins of Mass Immigration in Brazil, 1871-1914”. Ph.D Dissertation. Columbia University. 1969. "Review: Anarchists and Communists in Brazil, 1900-1935". The Americas. Vol 31, No. 2. 1974. pp. 219-221.

Hall, Michael M. and Marco Aurélio Garcia. "Urban Labor". In Modern Brazil: Elites and Masses in Historical Perspective. Eds. Michael L. Conniff and Frank D. McCann. Lincoln, NE: University of Nebraska Press. 1989. pp. 161-91.

Hanley, Ann. Native Capital: Financial Institutions and Economic Development in São Paulo, Brazil, 1850-1920. Stanford, CA: Stanford UP. 2005.

Hansen, Mark Hillary. "Eduardo Prado, Liberal Monarchist and Catholic Nationalist: A Whig Rebel in Brazil's Old Republic". PhD Dissertation: Columbia University. 2002.

Hardman, Francisco Foot. "Poeira das Barricadas: Notas Sobre a Comunidade Anárquica”. In O Desejo, ed. Adauto Novaes. São Paulo: Companhia Das Letras. 1990. pp. 261-67.

Hauf, Petra and Friedrich Försterling, eds. Making Minds: The Shaping of Human Minds through Social Context. Philadelphia, PA: John Benjamin's Publishing Company. 2007.

Hennacy, Ammon. The Autobiography of a Catholic Anarchist. New York, NY: Catholic Worker Books. 1954.

"História de Mogi-Mirim". City Brazil. 2007. http://www.citybrazil.com.br/sp/mogimirim/historia.htm. Retrieved Jan. 15th 2008

Holloway, Thomas H. Immigrants on the Land: Coffee and Society in São Paulo, 18861934. Chapel Hill, NC: University of North Carolina Press. 1980.

Holloway, Thomas H. "Creating the Reserve Army? The Immigration Program of São Paulo, 1886-1930”. International Migration Review. Vol. 12, No. 2. 1978. pp. 187-209. 
James, Daniel. Doña María's Story: Life History, Memory and Political Identity. Durham, NC: Duke UP. 2000.

Jenkins, Richard. Social Identity. London, UK: Routledge. 1996

Jensen, Derrick. Endgame, Volume 1: The Problem of Civilization. New York, NY: Seven Stories Press. 2006

“João Jacques Rousseau: Julgado Por Pedro José Proudhon". A Provincia de São Paulo. Jan. 9th, 1886.

Kellner, Douglas. Critical Theory, Marxism, and Modernity. Baltimore, MA: John Hopkins UP. 1989.

Khoury, Yara Aun. "Edgard Leuenroth: Uma vida e um arquivo libertários". Revista Brasileira de História. Vol. 17, No. 3. 1997. pp. 112-49. As Greves de 1917 Em São Paulo E O Processo De Organização Proletária. São Paulo: Cortez Editora/Autores Associados. 1981.

Kowarick, Lúcio and Clara Ant "One Hundred Years of Overcrowding: Slum Tenements in the City". In Social Struggles and the City: The Case of Sao Paulo. Ed. Lúcio Kowarick. New York, NY: Monthly Review Press. 1994. pp. 60-76.

Kropotkin, Peter. Mutual Aid: A Factor of Evolution. New York, NY: Dover. 2006. - The Conquest of Bread and Other Writings. Ed. Marshall S. Shatz. New York, NY: Cambridge UP. 1995.

Laclau, Ernesto and Chantal Mouffe. Hegemony \& Socialist Strategy: Towards a Radical Democratic Politics. Trans. Winston Moore and Paul Cammack. London, UK: Verso. 1985.

Lane, A. Thomas, Ed. Biographical Dictionary of European Labor Leaders. Westport, CT: Greenwood. 1995. p. 692

Leckie, Shirley A. "Biography Matters: Why Historians Need Well-Crafted Biographies More than Ever". In Writing Biography: Historians and their Craft. Ed. Lloyd E. Ambrosius. Lincoln, NE: University of Nebraska Press. 2004. pp. 1-26

Lesser, Jeffrey. Negotiating National Identity: Immigrants, Minorities, and the Struggle for Ethnicity in Brazil. Durham, NC: Duke UP. 1999.

Leuenroth, Edgard. Anarquismo: Roteiro da Libertação Social. Rio de Janeiro: Editôra Munda Livre. 1963.

Leuenroth, Edgard and Cruz. O Boi. Ano. 1, Num. 5. September 12th, 1897. 
Levi, Darrell E. The Prados of São Paulo, Brazil: An Elite Family and Social Change, 1840-1930. Athens, GA: University of Georgia Press. 1987.

Levine, Robert M. Father of the Poor? Vargas and his Era. Cambridge, UK: Cambridge UP. 1998. “'Mud-Hut Jerusalem': Canudos Revisited". In The Abolition of Slavery and the Aftermath of Emancipation in Brazil. Eds. Rebecca J. Scott, Seymour Drescher, Hebe Maria Mattos de Castro, George Reid Andrews and Robert M. Levine. Durham, NC: Duke UP. 1988. pp. 119-165 Vale of Tears: Revisiting the Canudos Massacre in Northeastern Brazil, 1893-1897. Berkeley, CA: University of California Press. 1992. - "Canudos in the National Context". The Americas. Vol. 48, No. 2. 1991. pp. 207-8.

Columbia UP. 1970. p. 22

Lewin, Linda. "Review: The Prados of São Paulo". The American Historical Review. Vol. 94, No. 4. 1989. pp. 1211-13.

Lopes, Milton. "José Oiticica: Uma Existência Pela Ação Direta". Boletim do Núcleo de Pesquisa Marques da Costa. Ano. III, n. 6. May 2007.

Love, Joseph L. São Paulo in the Brazilian Federation, 1889-1937. Stanford, CA: Stanford UP. 1980.

Luebke, Frederick C. Germans in the New World: Essays in the History of Immigration. Urbana, IL: University of Illinois Press. 1990.

Maram, Sheldon L. "Labor and the Left in Brazil, 1890-1921: A Movement Aborted". Hispanic American Historical Review. Vol. 57, No. 2. 1977. pp. 254-272

“Master of His Market”. Time Magazine. Oct. 30th, 1964.

Mattoon, Robert H. Jr. "Railroads, Coffee, and the Growth of Big Business in São Paulo, Brazil”. Hispanic American Historical Review. Vol. 57, No. 2. 1977. pp. 273-95.

Mead, George Herbert. Mind, Self and Society: from the Standpoint of a Social Behaviorist. Chicago, IL: University of Chicago Press. 1934.

Meade, Teresa A. 'Civilizing' Rio: Reform and Resistance in a Brazilian City, 1889-1930. University Park, PA: Pennsylvania State UP. 1997.

McCabe, Joseph. The Martyrdom of Ferrer. London: Watts \& Co. 1909.

McCann, Bryan. Hello, Hello Brazil: Popular Music in the Making of Modern Brazil. Durham, NC: Duke UP. 2004 
McVea, John. "Herbert Spencer - Providing Libertarian Foundations?" Business and Society Review. Vol. 106, No. 3. 2001. p. 225-40

Musacchio, Aldo. "Laws vs. Contracts: Legal Origins, Shareholder Protections, and Ownership Concentration in Brazil, 1890-1950". Working Paper No. 08-053. Harvard Business School. Jan. 2008. pp. 1-39

Nava, Carmen. "Lessons in Patriotism and Good Citizenship: National Identity and Nationalism in Public Schools during the Vargas Administration, 1937-1945". LusoBrazilian Review. Vol. 35, No. 1. 1998. pp. 39-63.

Needell, Jeffrey D. "The Domestic Civilizing Mission: The Cultural Role of the State in Brazil, 1808-1930”. Luso-Brazilian Review. Vol. 36, No. 1. 1998. pp. 1-18

"Nominal Exchange Rate for Brazil, 1900-1917". Oxford Latin American Economic History Database. Oxford University. 2008.

"Noticias". A Provincia de São Paulo. Feb 27th 1885. p. 2

Nugent, Walter. Crossings: The Great Transatlantic Migrations, 1870-1914. Bloomington, IN: Indiana UP. 1992.

“O Despertar”. A Guerra Social. Ano 1, Num. 10. 18 Jan 1912. p. 2

Oiticica, José. “Método de Ação”. In Anarquismo: Roteiro da Libertação Social. Ed. Edgard Leuenroth. Rio de Janeiro: Editora Mundo Livre. 1963. pp. 47-8

Paoli, Maria Célia. "Working Class São Paulo and its Representations, 1900-1940". Latin American Perspectives. Vol. 14:2 Urban Latin America. 1987. pp. 204-225.

Perissinotto, Renato Monseff. "State and Coffee Capital in São Paulo's Export Economy (Brazil 1889-1930)". Journal of Latin American Studies. Vol. 35, No. 1. pp. 1-23

Peixoto, Fernando, Susana Epstein and Richard Schechner. "Brazilian Theatre and National Identity". TDR. Vol. 34, No. 1. 1990. pp. 60-69

Phillips, Tom. "Raids across Brazil Free 4,000 Slaves". The Guardian. Jan $16^{\text {th }} 2006$. p. 22 http://www.guardian.co.uk/world/2006/jan/16/brazil.mainsection

Pinheiro, Paulo Sérgio and Michael M. Hall. A Classe Operária no Brasil, 1889-1930. Vol. 1 - O Movimento Operário. São Paulo: Editora Alfa Omega. 1979.

Prado, Antonio Arnoni. "Cenário para um retrato: Ricardo Gonçalves". In: Libertários no Brasil: Memória, Lutas, Cultura. Ed. Antnio Arnoni Prado. São Paulo: Editora Brasiliense. 1986. 
Proudhon, P. - J. What is Property? McLean, VA: Indypublish.com; No Date.

Rezende, Marcos. "Anarquismo, Igreja Pastoral do Imigrante". Revista Expressão. No. 1. 2000

Rizzini, Irene. "The Child-Saving Movement in Brazil". In Minor Omissions: Children in Latin American History and Society. Ed. Tobias Hecht. Madison, WI: University of Wisconsin Press. 2002. pp. 165-178

Rocker, Rudolf. Anarcho-Syndicalism: Theory and Practice. Oakland, CA: AK Press. 2004.

Rodrigues, Edgar. "A History of the Anarchist Movement in Brazil". In Against All Tyranny! Essays on Anarchism in Brazil. Ed. Paul Sharkey. Berkeley, CA: Kate Sharpley Library. 2003. pp. 1-15.

."Edgard Leuenroth, 1881-1968". In Against All Tyranny! Essays on Anarchism in Brazil. Trans. \& ed. by Paul Sharkey. Berkeley, CA: Kate Sharpley Library. 2003. pp. $19-20$

-

Comunitária. 1996. pp. 1-13

-- Os Companheiros 2. Rio de Janeiro: VJR - Editores Associados. 1995.

---_- Os Companheiros - 1. Rio de Janeiro: VJR - Editores Associados. 1994 Os Libertários. Rio de Janeiro: Editores Associados. 1993.

Editora. 1984. Os Anarquistas: Trabalhadores Italianos no Brasil. São Paulo: Global

-... Trabalho e Conflito: Pesquisa Histórica, 1900-1935. Rio de Janeiro: Gráfica Editora Arte Moderna. 1977.

- - Nacionalismo \& Cultura Social. Rio de Janeiro: Laemmert. 1972 . Socialismo e Sindicalismo no Brasil. Rio de Janeiro: Laemmert. 1969.

Rothbard, Murray. Man, Economy, and State with Power and Market. Scholar's Version. Auburn, AL: Ludwig Von Mises Institute. 2004.

Schmidt, Benicio Viero. "Modernization and Urban Planning in $19^{\text {th }}$ Century Brazil". Current Anthropology. Vol. 23, No. 2. 1982. pp. 255-62

Schultz, Kirsten. Tropical Versailles: Empire, Monarchy, and the Portuguese Royal Court in Rio de Jeneiro, 1808-1821. New York, NY: Routledge. 2001.

Schuzman, Mark D. "Childhood Education and Politics in Nineteenth Century Argentina: The Case of Buenos Aires". The Hispanic American Historical Review. Vol. 70: 1. 1990. pp. $109-138$ 
Schwartz, Stuart. "The Colonial Past: Conceptualizing Post-Dependentista Brazil". In Colonial Legacies: The Problem of Persistence in Latin American History. Ed. Jeremy Adelman. New York, NY: Routledge. 1999. pp. 175-92.

Scott, Joan W. Gender and the Politics of History. New York, NY: Columbia UP. 1999.

Selcher, Wayne A. "A New Start Toward a More Decentralized Federalism in Brazil?" Publius. Vol. 19, No. 3. 1989. pp. 167-83

Serva, Mario Pinta. “A energia paulista”. O Estado de São Paulo. 9 Jul. 1917. p. 4

Shecaira, Sérgio Salomão. "Racism in Brazil: A Historical Perspective" Revue Internationale de Droit Pénal. Vol. 73. 2002. pp. 141-153

Simis, Anita. "Movies and Moviemakers under Vargas". Latin American Perspectives. Vol. 29, No. 1. 2002. pp. 106-114

Skidelsky, Robert. "Only Connect: Biography and Truth". In The Troubled Face of Biography. Eds. Eric Homberger and John Charmley. London, UK: The Macmillan Press. 1988. pp. 1-16

Skidmore, Thomas E. Black Into White: Race and Nationality in Brazilian Thought. Durham, NC: Duke UP. 1993

--------.-- "Eduardo Prado: A Conservative Nationalist Critic of the Early

Brazilian Republic, 1889-1901". Luso-Brazilian Review. Vol. 12:2. 1975. p. 149-61

Stolcke, Verena. Coffee Planters, Workers, and Wives: Class Conflict and Gender Relations on São Paulo Plantations, 1850-1980. Basingstoke, UK: Macmillan. 1988.

“The Knight of Wisdom”. Pesquisa FAPESP. Vol. 70. Nov. 2001.

Tolstoy, Leo. The Kingdom of God is Within You. New York, NY: Dover. 2006

Topik, Steven and Mario Samper. "The Latin American Coffee Commodity Chain: Brazil and Costa Rica". In From Silver to Cocaine: Latin American Commodity Chains and the Building of the World Economy, 1500-2000. Eds. Steven Topik, Carlos Marichal, and Zephyr Frank. Durham, NC: Duke UP. 2006. pp.118-46

Topik, Steven. "Brazil's Bourgeois Revolution?" The Americas. Vol. 48, No. 2. 1991. pp. 245-271 The Political Economy of the Brazilian State, 1889-1930. Austin, TX: University of Texas Press. 1987.

"Traços biográficos de um homem extraordinário". Dealbar. São Paulo. 17 dez. 1968. Ano.2: 17. 
Welch, Cliff. The Seed Was Planted: The São Paulo Roots of Brazil's Rural Labor Movement, 1924-1964. University Park, PA: Pennsylvania UP. 1999.

Weinstein, Barbara and Daryle Williams "Vargas Morto: The Death and Life of a Brazilian Statesman" In Death, Dismemberment and Memory: Body Politics in Latin America. Ed. Lyman Johnson. Albuquerque, NM: University of New Mexico Press. 2004. pp. 273-315.

Weinstein, Barbara. For Social Peace in Brazil: Industrialists and the Remaking of the Working Class in São Paulo, 1920-1964. Chapel Hill, NC: The University of North Carolina Press. 1996.

"Review: Brazilian Regionalism". Latin American Research Review.

Vol. 17, No. 2. 1982. pp. 262-76

Wolfe, Joel. Working Women, Working Men: São Paulo and the Rise of Brazil's Industrial Working Class, 1900-1955. Durham, NC: Duke UP. 1993.

Wolfe, Joel. "Anarchist Ideology, Worker Practice: The 1917 General Strike and the Formation of Sao Paulo's Working Class". Hispanic American Historical Review. Vol. 71, No. 4. 1991. pp. 809-846.

Woodcock, George. Anarchism. Peterborough, ON: Broadview Press. 2004.

Woolf, Virginia. "In Search of a Room of One's Own" in The Norton Reader. Shorter $10^{\text {th }}$ edition. Eds. Linda H. Peterson et al. New York, NY: W.W. Norton \& Company. 2000. pp. 591-600

Zerzan, John. Future Primitive: And Other Essays. Brooklyn, NY: Autonomedia. 1994.

Žižek, Slavoj. The Sublime Object of Ideology. New York, NY: Verso. 1989.

Zimmermann, Eduardo A. "Racial Ideas and Social Reform: Argentina, 1890-1916". The Hispanic American Historical Review. Vol. 72, No. 1. 1992. pp. 23-46. 